\title{
Growing Apart? Structural Transformation and the Uneven Development of British Cities
}

\author{
Peter Tyler*, Emil Evenhuis**, Ron Martin**, Peter Sunley*** \\ and Ben Gardiner** \\ * Department of Land Economy, University of Cambridge, UK \\ ** Department of Geography, University of Cambridge, UK \\ *** School of Geography and Environment, University of Southampton, UK
}

July 2017

Submitted to Cambridge Journal of Regions, Economy and Society

Acknowledgments: This research for this paper was undertaken as part of a project funded by the ESRC (ES/N006135/1) into Structural Transformation, Adaptability and City Economic Evolutions, as part of its Urban Transformations Programme. We are grateful to the ESRC for its support. The full team on the project also includes David Bailey (Aston Business School, UK) and Andy Pike (Centre for Urban and Regional Development Studies, Newcastle University, UK). Their support for this paper is also gratefully acknowledged. 


\section{Abstract}

Structural change is now widely considered to be an important aspect of national economic growth. Yet the issue is not only of relevance at the macro-economic level; it also has a direct bearing on the growth of regions and cities. In this paper we examine the relationship between structural transformation and economic (output) growth across British cities over the last half century. During this time, the British economy has gone through a series of extensive structural transformations, most notably an historical shift from an industrial to a post-industrial structure. But also within the now dominant 'post-industrial' economy some service activities have been growing at a faster rate and appear to be more dynamic, than others. In this paper we show how the structural transformations in the national economy have played out quite differently across British cities, shaping to a considerable extent their divergent growth trajectories over the past five decades. At a broad level, it is possible to distinguish between a number of distinct growth groups of cities, and these also display significant differences in the extent and direction of structural change and reorientation. However, while differences in structural change have certainly been important in shaping city growth paths, other, 'city-specific', factors appear also to have exerted an influence, and thus require investigation.

Keywords: Cities Structural change Growth

\section{JEL Classifications R11 R12 047}




\section{Growing Apart? Structural Transformation and the Uneven Development of British Cities}

\section{Structural Transformation and City Growth}

The period since the Oil Crisis of the early 1970s has been one of great structural change in the British economy. Britain has lost much of its industrial base and experienced rapid growth in the service sector. Whilst structural change has affected virtually every aspect of the British economy, perhaps one of the most significant impacts has been on the economic growth of its cities, particularly its large conurbations that owed much of their rapid expansion throughout the eighteenth and nineteenth centuries to Britain's industrialisation. Many of Britain's largest cities have struggled to adjust to a post-industrial economy. As cities have lost manufacturing jobs they have experienced periods of high, often long-term unemployment, and in more recent years whilst there have been more job opportunities these have often been relatively poorly paid, and thus contributed to increased levels of income inequality across British society (Fenton, et al 2008).

Despite the importance of structural change on the growth trajectories of cities, it is perhaps somewhat surprising that there is relatively little in-depth analysis of the phenomenon. In the British case, the most comprehensive analysis to-date appears to have been undertaken some thirty years ago (see Hausner, 1987). At that time, an extensive (ESRC funded) research project considered how British cities, and their hinterlands, had adapted to economic change over the period 1951-1981. More recently, a UK Government Office for Science's Foresight Project on The Future of Cities showed that the growth paths of British cities have been quite diverse (Martin, Tyler and Gardiner, 2015), a finding reinforced by other recent work (Martin et al., 2016a). Thus, the Foresight Report observed that:

"Economic growth over the past three decades or so has been highly unequal and divergent across the UK's main cities. Many of the former industrial large towns and cities of northern Britain have lagged persistently behind those in the south. The weaker performance of many of the northern cities has attracted Government attention in the past few years. Improving the growth performance in the country's northern cities is seen as a way to increase jobs and incomes for the people living there, but also improve the UK's productivity'. (Martin et al, 2015).

How cities deal with structural transformation over time, and the concomitant changes in conditions and opportunities for their economic growth, are clearly major issues for society and the formulation of policy. Indeed, in Britain as government devolves economic powers from central to local government it is important that those tasked with managing city economies understand the basic mechanisms that lie behind change, and what may be the scope for intervention to assist the process in a way that enhances local economic growth. Policy makers need to know more about the sectors that are declining, those that may be experiencing successful upgrading or 'turning around', and those that are new and growing. This knowledge can help them to understand more about how to assist their economies to 
adapt and adjust their structures in response to both the challenges and opportunities of a rapidly changing globalised market place.

Cities grow for a variety of reasons (see Storper, 2013). Indeed, a large body of economic theory now exists concerned with why economic activity agglomerates in cities, how agglomeration influences productivity, human capital formation, wages and innovation, and the role played by planning systems (the literature is extensive, but see, for example, Fujita and Thisse, 2002; Henderson, 2003; Glaeser, 2008; Glaeser and Gottlieb, 2009; Cheshire et al. 2014). These key insights are most certainly relevant for understanding city growth. However, these literatures have much less to say about the medium to long-term evolution of city economies, about structural transformation and its relationship to diverse city growth paths.

Structural transformation refers to the changing sectoral composition of output and employment over time, a stylised fact for which there is copious evidence (Kuznets, 1957, 1971; Pasinetti, 1993; Freeman and Louca, 2001; Cornwall and Cornwall, 1994; Metcalfe, Foster and Ramlogan, 2006; Kruger, 2008). Traditional growth theory always had difficulty incorporating structural change, although the notion has found extensive use within the study of economic development. But for those economists who reject the distinction between development and growth (see Kuznets, 1971; Pasinetti, 1981; Baranzi and Scazzieri, 1990; Rodrik, 2006), and for present-day evolutionary economists (such as Metcalfe, 2003; Metcalfe et al, 2006), structural change or structural transformation is an integral feature of a dynamic modern economy, and the study of 'structural dynamics' necessary for understanding the growth process. As Roncolato and Kucera (2014, p. 399) put it, "sustainable economic growth requires structural transformation". Similarly, in the new evolutionary economic geography, particular attention is focused on the path dependence of local economic structures, on the process of new path creation - that is the emergence of new industries and technologies and on the adaptability and resilience of local economies (see Martin and Sunley, 2006; Boschma and Martin, 2010; Pike et al, 2010; Bailey and Berkeley, 2014; Martin and Sunley, 2015).

It took the path-breaking work of authors such as Kaldor $(1966,1967,1968)$, Kuznets (1973) and Pasinetti $(1981,1993)$ to move structural change to centre stage in growth theory. Thus according to Kuznets

rapid changes in production structure are inevitable - given the differential impact of technological innovations on the several production sectors, the differing income elasticity of domestic demand for various consumer goods, and the changing comparative advantage in foreign trade (1973, p. 250).

Likewise, in Pasinetti's scheme, structural change is conceived as a multi-sectoral economy evolving through time under the influence of technical progress and changes in final demand consumption. Technical change occurs unevenly among sectors, so that the rate of change of 
productivity differs from sector to sector (and by implication from region to region). ${ }^{1}$ Correspondingly, demand changes at different rates among different products. Moreover, technical change may take the form of the introduction of new products, and hence the emergence of new activities and new sectors. In short, structural dynamics are inherent to the growth process. In Kaldor's seminal works on economic growth theory, manufacturing was assigned particular importance as the driver of economic growth primarily because it has greatest potential for dynamic returns to scale (Kaldor, op cit; see also Thirlwall, 1983), the implication being that a shift to services could well slow down productivity growth. In a later contribution, Baumol et al (1989) discuss the considerable diversity of productivity developments that can be observed across industries and sectors, and emphasise not only the fact that structural change is an ongoing long-run phenomenon, but also that productivity growth is particularly relevant in the long run.

Empirically, structural transformation has in recent decades been particularly apparent and disruptive through the process of deindustrialisation. Deindustrialisation refers to the contraction and decline of the weight of manufacturing industry within an economy (Martin and Rowthorn, 1986; Pike, 2009). This may only be a relative decline (loss of importance of manufacturing as a proportion to other sectors), but there may also be an absolute decline (decline in output and employment). In many of the most advanced economies in Western Europe and North America a relative decline of manufacturing began in the 1960s, with the service sector growing at a faster rate than manufacturing. But especially after the first oil crisis of 1973, the pace of change accelerated, and in many traditional segments of manufacturing (such as steel, shipbuilding, heavy engineering, car manufacturing, chemicals, etc.) an absolute decline in employment (and in some sectors, also output) set in. This coincided with large-scale rationalisation- and modernisation-operations with concomitant downsizing and plant-closings (Bluestone and Harrison, 1982).

The 'maturity thesis' regarding deindustrialisation postulates that the relative decline of manufacturing is a 'natural' consequence of rising incomes and living standards, as consumer demand shifts from manufactured goods to services of various kinds (Rowthorn, 1986; Hudson, 2011). This parallels some of the theoretical insights of Kuznets, Pasinetti, and Kaldor cited earlier. In addition, as economies develop, their comparative advantages vis-à-vis other economies will change; so there will be increasing pressures to shift into in more high-value economic activities which correspond with higher wages and higher skill-levels (Pike, 2009; Hudson, 2011). Forms of manufacturing which mainly rely on cheap and semi-skilled labour will then move to other places where wages, living standards and overall levels of education are lower. These factors have meant that - in economically advanced nations - the scope for output growth in manufacturing has been smaller than in other sections of their economies. Moreover, technological change and productivity improvements have meant that

\footnotetext{
${ }^{1}$ Interestingly, in explaining the stimulus for his new theory, Pasinetti attributed it in part to "the extremely uneven development - from sector to sector, from region to region - of the environment in which I lived (postwar Europe) at the time I began my training in economics" (Pasinetti, 1981; p. xi).
} 
employment in industry has fallen drastically, as a consequence of on-going automation and the increasing importance of economies of scale.

Some of these patterns of deindustrialisation seem to be mirrored by recent trends of structural transformation within the service sector. Some tradeable parts of the service sector - in particular those providing 'innovation jobs' (Moretti, 2013), such as IT, life sciences, finance, advertising, design, entertainment, etc. - exhibit considerable dynamism and show continuing growth in employment and output. Other segments of the service sector, such as personal services, leisure activities health care, and education, have been more stagnant in terms of the application of new technologies; and while experiencing substantial employment growth they have shown much slower productivity advance (Berger and Frey, 2016; LSE Growth Commission, 2017). How far new advances in digitalisation, robotics and machine learning, will threaten jobs in these activities is an increasingly pertinent issue (Berger and Frey, 2016; Baldwin, 2016). But some recent accounts have argued that mature economies such as the UK are experiencing a dominant shift of employment to low-productivity, nontradable services, and that this can be described as 'growth-reducing structural change' as it will weaken future innovation and productivity growth (Rodrik, 2016). The balance between different types of service industry growth is clearly crucial.

These structural transformations have affected different cities and regions differently across Europe and North America. Certain places in which manufacturing formed the backbone of their economy were especially badly affected by deindustrialisation, undergoing serious falls in industrial employment. After the initial shock in the 1970s and 1980s, some of these places managed to find renewed growth in advanced manufacturing and service industries; but recovery has been very uneven (Birch et al., 2010; Power et al., 2010; Hobor, 2013; Cowell, 2015). In part, the success with which cities have reorientated their economies has depended on policies adopted during and after deindustrialisation, and the institutional structures within which cities and regions operate (especially with regard to the powers and resources available at the subnational level). Indeed, particular macro-economic policies - such as measures to protect the value of the currency and a lack of an industrial strategy - together with weak regional policies and an economic governance structure which is exceptionally centralised, have undoubtedly contributed to the particular intensity and high degree of disruption of deindustrialisation in the United Kingdom (Martin, 1986; Pike 2009; Birch et al., 2010; McCann, 2016). But many other factors also appear important in coping effectively with structural transformations, such as location, human capital formation, the knowledge and innovation base, agglomeration effects, infrastructure connections, entrepreneurial culture, etc. These determine whether an urban economy manages to develop new activities that incorporate important and dynamic functions (i.e. especially 'innovation jobs') in national and international value chains, reducing its dependence on 'branch plants', public sector expenditure, and low-productivity services (Massey, 1995; Moretti, 2013; Baldwin, 2016; Storper et al., 2015). Such activities will then also contribute to its tradeable base and generate additional income within the economy of the city, driving employment and output 
in other activities through multiplier effects (Rowthorn, 2010; Moretti, 2013; Martin et al., 2016a). A growing body of work in economic geography has examined how industries emerge from related and antecedent sectors. It has been argued that those cities that possess a platform of technologically related industries are better able to diversify and adapt their economies by spawning more new sectors and industries (Frenken and Boschma, 2007; Neffke et al, 2011). However, many of the claims about the ways in which the diversification and branching of industrial structures shape long-term urban growth have not been tested empirically.

In this article we examine how differences among cities in medium to long run growth, and shifts in the growth paths of cities relative to one another, are in part due to differences in the process, nature and extent of structural transformation. ${ }^{2}$ We have taken industrial sectors as the unit of our analysis (rather than, say, types of firms) and have considered structural transformation in Britain as it relates to a process in which some sectors expand relatively quickly and thus increase their relative share of national output, whilst others do the opposite.

\section{City Growth Evolutions}

The growth path of a given city is the outcome of a complex and evolving interaction of 'external' (national and indeed global) factors and city-specific factors and conditions. Following Metcalfe et al (2006), we can think of a city's economy as being an ensemble' of activities - a structural ensemble - that is constantly changing as a result of this interaction. Such a structural ensemble can be examined and decomposed in different ways, of course. Our analysis has taken industrial sectors as the primary units of a city's structural ensemble. However, it is entirely plausible to distinguish other constituent elements, like types (or sizes) of firms or occupational composition. Ultimately, structural change will involve several such dimensions: for example, the decline of manufacturing jobs is almost certain to lead to the decline or even disappearance of certain types of occupation. Nevertheless, given our interest is in the 'great transformation' from an industrial to a post-industrial economy, we focus attention here on sectors. ${ }^{3}$ The differential growth of a city's firms and industrial sectors imparts structural transformation, while the aggregate pattern of that transformation will shape a city's growth path, relative to other cities. An ensemble approach suggests that the development of industries in a particular city may be strongly or weakly inter-related (e.g. through demand linkages, skills and knowledge spillovers) so that the performance of an

\footnotetext{
2 The research for this paper was undertaken as part of a project funded by the ESRC (ES/N006135/1) into Structural Transformation, Adaptability and City Economic Evolutions, as part of its Urban Transformations Programme. We are grateful to the ESRC for its support.

${ }^{3}$ We also have constructed time series on the occupational structures of our 85 cities, from 1971 to 2014 . The analysis of this aspect of city growth and change will form the basis of another paper.
} 
industry in a particular urban area may depend on how it is set within and interacts with a wider group of local industries.

What is to be analysed and explained are the differential growth rates of output, employment and productivity across an industrial ensemble - here the sectoral ensemble of a city. Without differential growth there is no structural change, no evolution of the sectoral shares of city output, employment or productivity. If the growth rate of output in sector $i$ in city $j$ is denoted by $g_{i j}$, the growth rate of aggregate output in the city by $g_{j}$, and the growth rate of the share of sector $i$ in the total output of the city by $s_{i j}^{g}$, then by definition

$$
s_{i j}^{g}=g_{i j}-g_{j}
$$

and similarly for employment

$$
s_{i j}^{e}=e_{i j}-e_{j}
$$

Obviously, if all growth rates, $g_{i j}$ (or $e_{i j}$ ), are equal, the case of proportional growth, the output (employment) structure of a city is frozen, and there is no structural change or transformation. Further,

$$
s_{i j}^{e}+q_{i j}=s_{i j}^{g}+q_{j}
$$

where $q_{i j}$ and $q_{j}$ are the growth rates of productivity in sector $i$ in city $j$ and total city productivity respectively. Consequently, in an industry in which productivity increases at the city average rate, the output share of that sector will change at the same rate as its employment share. Hence proportionate growth implies that all sectors in a city have a common rate of productivity growth, which is unlikely to be the case. The key point is that the differential growth rates of the sectors making up a city's industrial ensemble, and what makes those growth rates differ, are of central importance in shaping that city's aggregate growth path over time and in relation to that of other cities.

\section{Constructing a New Cities Dataset}

A major constraint on examining the way on which British cities have grown and the contribution of economic structure is the lack of good quality sectorally disaggregated time series data on output (GVA) and employment. Since 1971 there have been a number of changes in the way in which industrial sectors are classified. Moreover, there have been changes in geographical boundaries that also complicate analysis. The starting point in the analysis was to produce a newly constructed dataset with data on GVA and employment (and by implication: productivity), with sectoral breakdown (82 sectors) for 85 cities in Great Britain for a standardized set of all Travel to work areas in Great Britain with a population of 200,000 or greater for each year from 1971 to 2015. Annex 1 provides details of the methodology adopted to construct the data. 
In order to examine the patterns of change across British cities we focus on cumulative differential growth, whereby, starting in our base year 1971, we subtract from each city's growth rate in each year the corresponding national (Great Britain) rate, and cumulate these differences over time (see Blanchard and Katz, 1992, for the development of this approach). The overall performance of the 85 cities, measured in terms of their cumulative differential growth in output and employment over 1971-2014, is shown in Figure 1.

Figure 1: Output growth and Employment growth over 1971-2014 in terms of cumulative percentage point deviation from national growth, for 85 British cities (including line of best fit and $R^{2}$ )

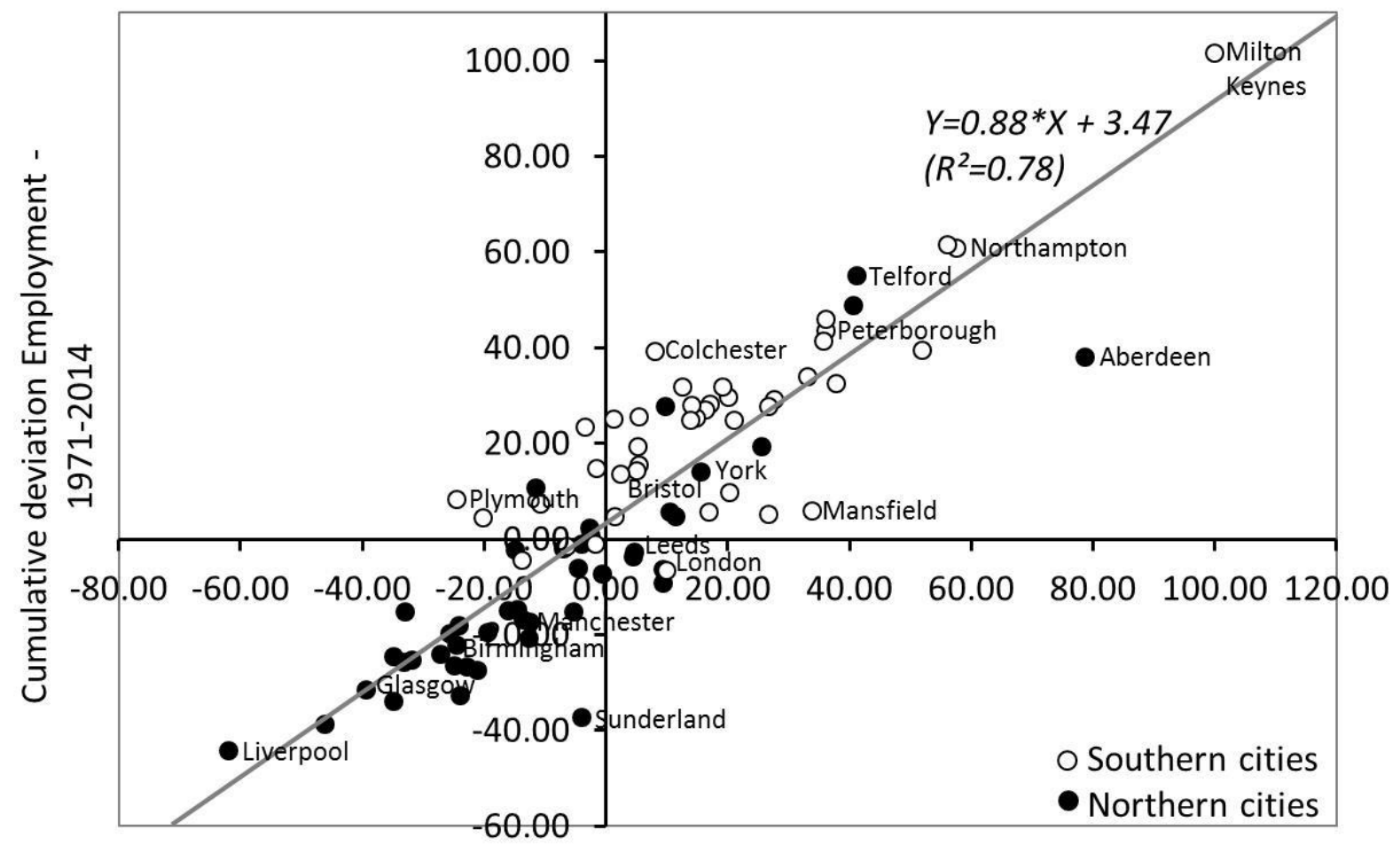

Cumulative deviation GVA - 1971-2014

Note: Southern cities defined as those in the following regions: London, South East, East of England, South West and East Midlands. Northern cities defined as those in the West Midlands, Yorkshire-Humberside, North West, North East, Scotland and Wales.

A number of features emerge. It is clear that the differential growth of both output and employment across cities has been substantial. Further, the patterns for output and employment are closely correlated: those cities that have experienced the fastest rates of growth of employment also tend to be those that have recorded the fastest rate of growth of employment, and vice versa. Some cities, such as Milton Keynes, Northampton, Telford, Crawley and Swindon have experienced average growth rates in their GVA and employment far exceeding the national average (and totalling to a cumulative differential of over 30-40 percent over the period). Other cities, such as Liverpool, Glasgow, Newcastle, Birmingham, and Sheffield have grown well below the national rate in both output and employment. Still other cities have tracked national growth. Notwithstanding the high correlation between 
output and employment growth, however, some cities show a much slower performance in employment than in output, such as Sunderland, Middlesbrough, Manchester and Huddersfield. Still other cities seem to experience much stronger employment growth compared to GVA growth, such as Colchester, Chelmsford, Plymouth and Southend.

Another feature is that many of the fastest growing cities have been in the southern half of Britain (roughly south of a line between the Severn and Humber), and most of the slowest growing have been in the north. Notable exceptions to the latter group are Aberdeen (which has benefited from the North Sea oil industry), Telford (a New Town in Shropshire), Leamington Spa and Crewe. It is perhaps not inappropriate to refer to the pattern evident in Figure 1 as closely corresponding to the conventional depiction of Britain's economic geography as mapping out a broad North-South' divide (Martin 1988; Lewis and Townsend, 1989; Rowthorn, 2010; Martin et al., 2016b).

We began our more detailed statistical analysis by excluding Aberdeen from our analysis because it had uniquely experienced a quite dramatic increase in its growth due to the impact of North Sea oil. We also separated out London because of its size and dominance as the United Kingdom's capital city. Our research interest was to categorise cities according to their relative growth performance over the study period. For our remaining 83 cities we thus used the Blanchard and Katz differential growth component to identify three distinctive groups; those that had grown faster than the nation which we termed cities 'pulling away' (group one); those cities which had grown slower than the national benchmark which we termed 'falling back' (group three) and thus cities which had 'kept pace' with the growth of the nation (group two).

Clearly, it was necessary to assess how robust our grouping of cities were according to distance from the national average mean growth and to test this we undertook an extensive body of sensitivity analysis which involved subjecting the categorisation to increased distance (or standard deviation) from the mean. This sensitivity testing showed that using four alternative 'distances' from the mean the grouping remained robust ${ }^{4}$. The only exception was Manchester which tended to move between group two or group three, partly due to a particularly averse economic performance since the recession. Table 1 shows which cities are in which group. The sensitivity analysis is presented in Annex 2. 
Table 1: Groups of British cities defined according to their relative GVA growth trajectory using half a standard deviation (unweighted) to distinguish above average and below average.

\begin{tabular}{|l|l|l|}
\hline Group I & GVA + & $\begin{array}{l}\text { Milton Keynes, Northampton, Basingstoke, Swindon, Telford, } \\
\text { Leamington Spa, Crawley, Peterborough, Chichester, Tunbridge Wells, } \\
\text { Mansfield, Reading, Guildford, High Wycombe \& Aylesbury, Derby, } \\
\text { Crewe, Norwich, Chesterfield, Bournemouth, Exeter, Cambridge, } \\
\text { Slough \& Heathrow, Lincoln, York, Southampton, Eastbourne, Ipswich }\end{array}$ \\
\hline Group II & GVA 0 & $\begin{array}{l}\text { Trowbridge, Dunfermline \& Kirkcaldy, Wakefield, Shrewsbury, Halifax, } \\
\text { Blyth \& Ashington, Colchester, Kettering \& Wellingborough, Oxford, } \\
\text { Stevenage, Gloucester, Doncaster, Leeds, Bristol, Nottingham, } \\
\text { Chelmsford, Falkirk \& Stirling, Luton, Leicester, Worcester \& } \\
\text { Kidderminster, Chester, Southend, Sunderland, Barnsley, Warrington } \\
\text { \& Wigan, Huddersfield, Brighton, Edinburgh, Bedford, Preston, } \\
\text { Durham \& Bishop Auckland, Bradford, Manchester }\end{array}$ \\
\hline Group III & GVA - & $\begin{array}{l}\text { Portsmouth, Coventry, Cardiff, Hull, Newport, Medway, Merthyr } \\
\text { Tydfil, Motherwell \& Airdrie, Middlesbrough \& Stockton, Sheffield, } \\
\text { Blackburn, Plymouth, Newcastle, Birmingham, Dudley, Birkenhead, } \\
\text { Blackpool, Stoke-on-Trent, Dundee, Swansea, Glasgow, } \\
\text { Wolverhampton, Liverpool }\end{array}$ \\
\hline London & London \\
\hline Aberdeen & & Aberdeen \\
\hline Non-urban & & TTWAs which are not classified as cities in our analysis. \\
TTWAs & &
\end{tabular}

Figure 2 shows the evolution of the growth of GVA relative to the nation for the Groups from 1971 until 2014. The relative fast growing city Group I had an average growth rate of $2.76 \%$ but some cities within the group did better than that, achieving almost $4.5 \%$. The overall average growth of Group I cities exceeded that of London by a significant margin, and that of the non-urban travel to work areas. The group grew over a third faster than the Group II that tracked the national rate. Group II had relatively little dispersion within it. Group III grew at around half the rate of Group I at $1.42 \%$, and there was wide group dispersion with the weakest performer growing at half the group average. 
Figure 2. GVA: Cumulative differential percentage growth relative to GB: London, Group I ('Pulling Ahead'), Group II ('Keeping Pace'), and Club III ('Falling Behind'), and Non-urban TTWAs.

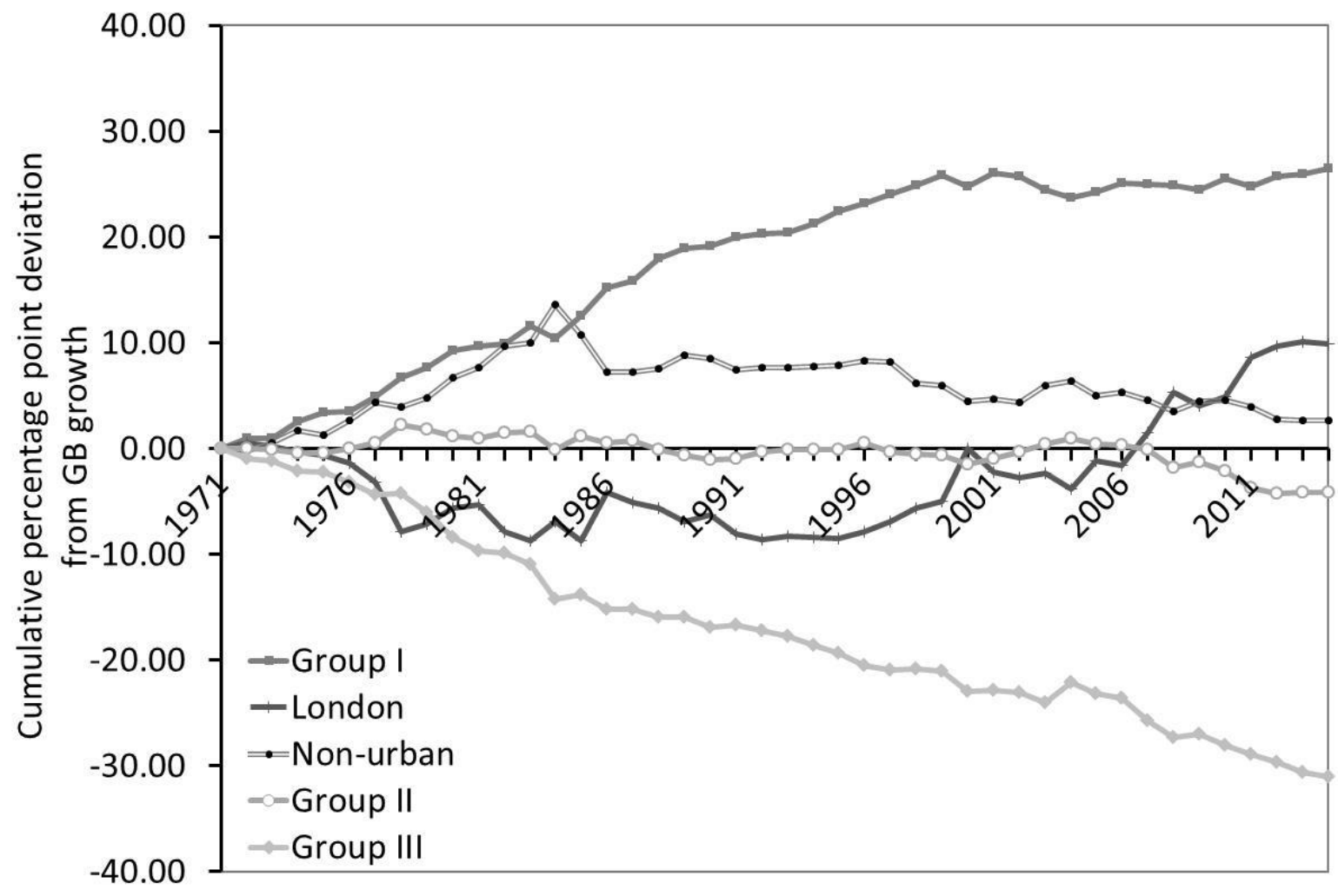

The cities in Group I have thus been characterised by very strong overall growth in output throughout the period of study; though this seems to have levelled off somewhat in the last 15 years of the period under investigation. This group includes Milton Keynes, Northampton, Telford, Peterborough, Reading, Cambridge, and Southampton. Several of these cities were promoted as New Towns and assisted by British spatial policy to become centres of growth. The New Town approach was to facilitate a planned approach to economic development whereby a Development Corporation was established with extensive powers relating to land assembly and the provision of infrastructure in order to promote economic development. The evidence suggests that they may have been quite successful in this respect. Group II has tracked the growth of the nation quite closely and includes cities like Oxford, Leeds, Bristol, Nottingham, Leicester, and Manchester. Group III comprises 23 cities that have more or less consistently grown well below the national rate. This group comprises many of the oldest industrial areas and includes Cardiff, Middlesbrough, Sheffield, Newcastle, Birmingham, Swansea, Glasgow, and Liverpool.

London shows a particularly interesting growth trajectory throughout the study period. After a period of relative decline up until the mid 1980s it then 'turned-around' and has grown relatively more quickly than that of the national average since. It is also of interest to note that the TTWA residual group has tended to grow slightly above the national average over the 
study period, in line with the relatively better performance of near accessible areas around the cities in the post-war period, as documented by Keeble and Tyler (1995).

\section{Structural Transformation in the British Economy}

As already noted earlier, the United Kingdom was the first major industrial nation to experience a strong relative decline in the growth of its manufacturing sector, a process that began in the mid-1960s, sometime before the same process affected other nations (Rhodes, 1986). It has also been the case that the United Kingdom has experienced the greatest relative employment decline in the sector of all its major competitors (Townsend, 1983). Figure 3 shows the broad pattern of output change in Britain over the period for larger aggregations of the 81 sectors (see Appendix). The differential growth performance across sectors reveals the scale of the change in the last five decades. As Table 2 shows, over the period overall output in the national economy has grown by around $150 \%$ since 1971 . As outlined in section

2 , sectors that have grown below the national average growth rate, will have seen their share in national output decrease, while sectors that have grown at a faster pace, will have expanded their share. Growth of output in manufacturing sectors, including high-tech has been far below the average, and hence their share has fallen: in some cases (especially in metals and textiles) output has actually declined. The sectors in which output has grown considerably faster than the British average - and hence now represent a larger share of output - have been oil and gas extraction, retail and personal services and especially Knowledge Intensive Business Services (KIBS).

The process of deindustrialisation has resulted in manufacturing declining from nearly $22 \%$ of output in 1971 to just over $10 \%$ of output in 2014. But also within the services some sections of the service economy (especially the Knowledge Intensive Business Services and to a lesser extent retail and personal services) have been growing at a faster rate than other sections. The share of services (both private and public) went from about $50 \%$ of output in 1971 to $68 \%$ in 2014; but within services, KIBS increased its share of total service output from about a quarter to nearly half. 
Figure 3: Sectoral growth across the British economy 1971-2014

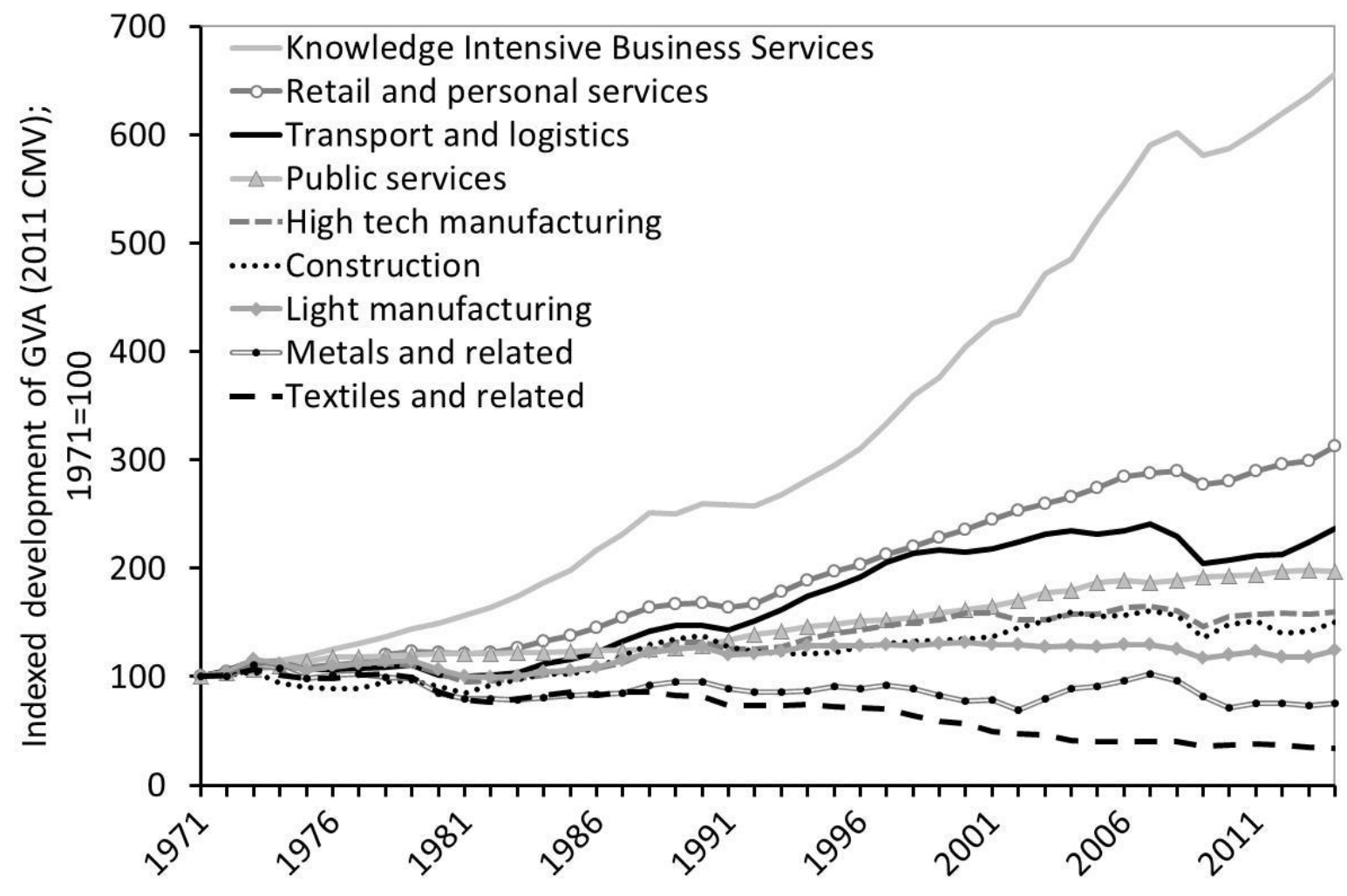

Table 2: Sectoral change across the British economy over 1971-2014

\begin{tabular}{lcc}
\hline & $\begin{array}{c}\text { Indexed change in GVA in 2014 } \\
\text { (base 1971=100) }\end{array}$ & $\begin{array}{c}\text { Indexed change of broad sector group } \\
\text { relative to growth of GB }\end{array}$ \\
\hline Agriculture and fishing & 158.6 & 63.6 \\
Coal and Other mining & 76.6 & 30.7 \\
Oil, Gas and Mining support & 400.9 & 160.7 \\
Metals and related & 75.0 & 30.1 \\
Textiles and related & 34.2 & 13.7 \\
Light manufacturing & 124.8 & 50.0 \\
High tech manufacturing & 160.1 & 64.2 \\
Utilities & 226.9 & 90.9 \\
Construction & 150.8 & 60.4 \\
Transport and logistics & 236.8 & 94.9 \\
Retail and personal services & 313.1 & 125.5 \\
Knowledge Intensive Business Services & 656.0 & 262.9 \\
Public services & 197.8 & 79.2 \\
Total & 249.5 & 100.0 \\
\hline
\end{tabular}

We can now identify the sectors which have managed to grow above average over the period from 1971-2014 (and thus have seen an expansion of their share), and those which have performed below average (and hence will have decreased their share). Moreover, we can further distinguish between sectors according to their labour productivity performance, which reflects their dynamism and capability to generate high-value employment. Figure 4 shows the 81 sectors plotted according to their annual average output growth and growth in productivity over the 1971-2014 period. We can distinguish between four performance types, 
which are listed in Table 3. The first group contains those sectors that have had a growth of output and productivity below the national average. This includes large sectors such as public administration and defence, education, and construction. The second group has had slow output growth, but above the national average productivity growth compared to the national average as a result of employment loss. This group includes most of manufacturing. The third group has had faster growth of output but slower productivity growth than the national average. This includes most personal services, health care, and several of the KIBS. The fourth group are those that have experienced relatively faster output and also productivity growth, and are thus the most impressive performers across the sectoral groups. This group encompasses most of the KIBS, retail, pharmaceuticals, and oil and gas extraction.

Figure 4: Sectoral growth in output and productivity in terms of annual compound growth rates over 1971-2014 (pecked lines indicate average rates for British economy as a whole)

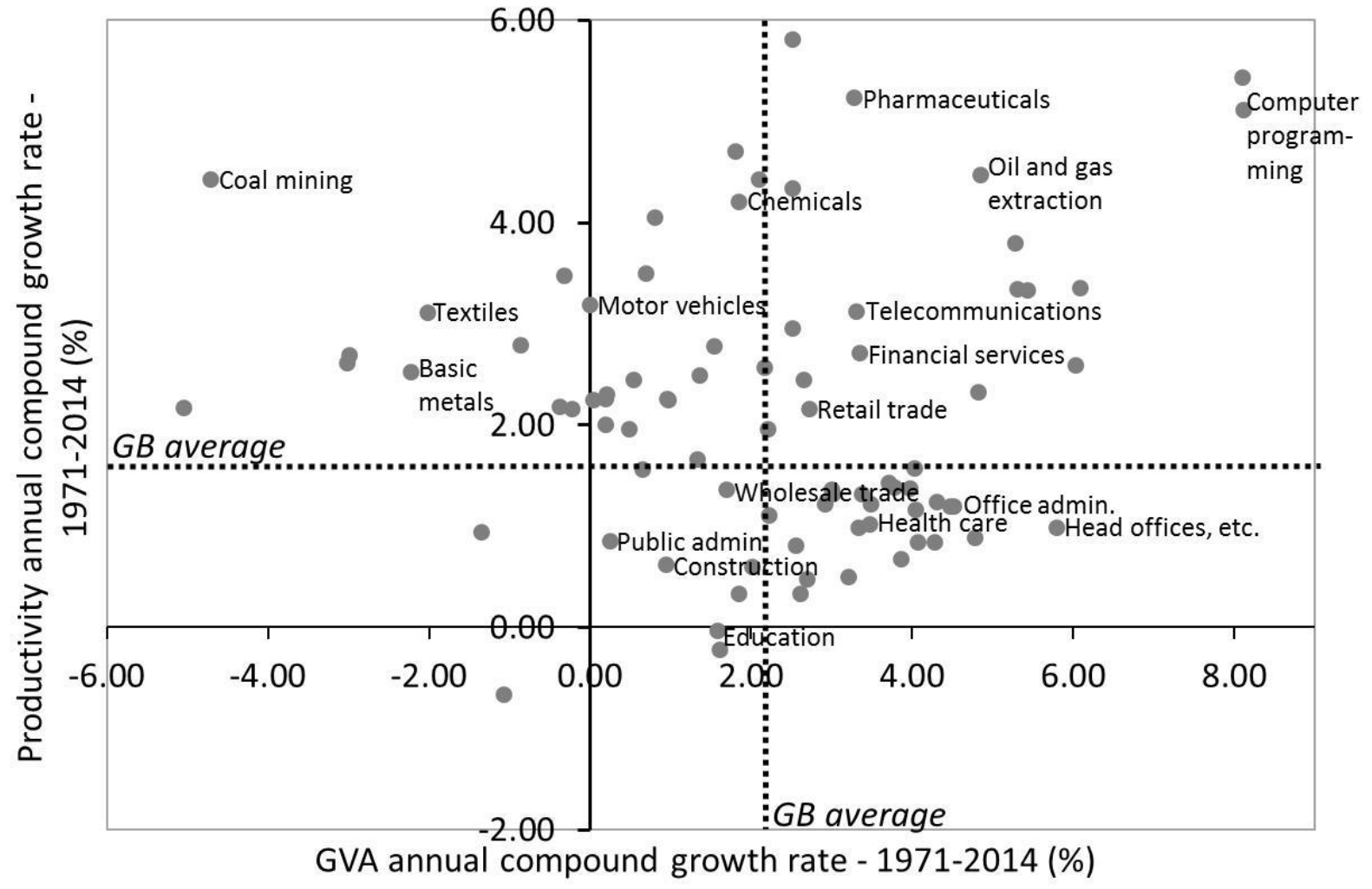


Table 3: Sectoral change across the British economy

\begin{tabular}{|c|c|c|c|c|}
\hline Performance type & Sectors & GVA change & $\begin{array}{l}\text { Productivity } \\
\text { change }\end{array}$ & $\begin{array}{l}\text { Employment } \\
\text { change }\end{array}$ \\
\hline $\begin{array}{l}\text { GVA below average, } \\
\text { Productivity below } \\
\text { average }\end{array}$ & $\begin{array}{l}\text { - Public administration and defence } \\
\text { - Education } \\
\text { - Construction } \\
\text { - Wholesale trade } \\
\text { - Accommodation and other leisure } \\
\text { services }\end{array}$ & $\begin{array}{l}\begin{array}{l}1.07 \% \text { on } \\
\text { annual basis }\end{array} \\
58.2 \% \text { over } \\
\text { period }\end{array}$ & $\begin{array}{l}0.41 \% \text { on } \\
\text { annual basis } \\
\begin{array}{l}19.4 \% \text { over } \\
\text { period }\end{array}\end{array}$ & $\begin{array}{l}0.66 \% \text { on } \\
\text { annual basis } \\
32.5 \% \text { over } \\
\text { period }\end{array}$ \\
\hline $\begin{array}{l}\text { GVA below average, } \\
\text { Productivity above } \\
\text { average }\end{array}$ & $\begin{array}{l}\text { - Most manufacturing } \\
\text { - Electricity and gas supply } \\
\text { - Water transport } \\
\text { - Insurance and pensions }\end{array}$ & $\begin{array}{l}0.33 \% \text { on } \\
\text { annual basis } \\
15.1 \% \text { over } \\
\text { period }\end{array}$ & $\begin{array}{l}2.85 \% \text { on } \\
\text { annual basis } \\
235.0 \% \text { over } \\
\text { period }\end{array}$ & $\begin{array}{l}-2.45 \% \text { on } \\
\text { annual basis } \\
-65.6 \% \text { over } \\
\text { period }\end{array}$ \\
\hline $\begin{array}{l}\text { GVA above average, } \\
\text { Productivity below } \\
\text { average }\end{array}$ & $\begin{array}{l}\text { - Most personal services } \\
\text { - Health care, residential care, and } \\
\text { social work } \\
\text { - Some KIBS } \\
\text { - Warehousing } \\
\text { - Waste disposal and management }\end{array}$ & $\begin{array}{l}\text { 3.74\% on } \\
\text { annual basis } \\
384.4 \% \text { over } \\
\text { period }\end{array}$ & $\begin{array}{l}1.12 \% \text { on } \\
\text { annual basis } \\
61.6 \% \text { over } \\
\text { period }\end{array}$ & $\begin{array}{l}2.59 \% \text { on } \\
\text { annual basis } \\
199.7 \% \text { over } \\
\text { period }\end{array}$ \\
\hline $\begin{array}{l}\text { GVA above average, } \\
\text { Productivity above } \\
\text { average }\end{array}$ & $\begin{array}{l}\text { - Most KIBS (including information } \\
\text { telecomices, computer programming, } \\
\text { research, and financial services) } \\
\text { - Retail } \\
\text { - Pharmaceuticals } \\
\text { - Oil and gas extraction, and support } \\
\text { activities } \\
\text { - Land transport } \\
\text { - Air transport }\end{array}$ & $\begin{array}{l}3.69 \% \text { on } \\
\text { annual basis } \\
374.5 \% \text { over } \\
\text { period }\end{array}$ & $\begin{array}{l}3.03 \% \text { on } \\
\text { annual basis } \\
260.2 \% \text { over } \\
\text { period }\end{array}$ & $\begin{array}{l}0.64 \% \text { on } \\
\text { annual basis } \\
31.7 \% \text { over } \\
\text { period }\end{array}$ \\
\hline $\begin{array}{l}\text { Total for Great } \\
\text { Britain }\end{array}$ & & $\begin{array}{l}2.15 \% \text { on } \\
\text { annual basis } \\
149.5 \% \text { over } \\
\text { period }\end{array}$ & $\begin{array}{l}1.59 \% \text { on } \\
\text { annual basis } \\
98.6 \% \text { over } \\
\text { period }\end{array}$ & $\begin{array}{l}0.55 \% \text { on } \\
\text { annual basis } \\
26.8 \% \text { over } \\
\text { period }\end{array}$ \\
\hline
\end{tabular}

\section{Structural Transformation in British cities}

This section is concerned to assess the how the structural transformation discussed in the previous section, has played out over the various cities in Great Britain. The economic growth prospects of cities will be importantly conditioned by the initial presence of certain sectors at the beginning of the period, and the general development of sectors over the period. Hence we will first look at how economic activities were distributed over the country in 1971 and how this has changed over the period until 2014. We will then analyse what this has meant for changes in GVA for the cities from 1971 until 2014.

Table 4 shows the economic structure of the groups of cities in 1971. Clearly manufacturing was still a relatively important segment of the economy, with nearly $22 \%$ of the output in the nation. It is also clear that there was an overrepresentation of manufacturing - which as highlighted in section 4, has grown very little - in Groups II and III, with Group II also 
specialising more in textiles and Group III more in metals and related industries. Private services - where a lot of the growth has taken place in the subsequent period - made up about $37 \%$ of the British economy in 1971 . There is not that much disparity between the economic structures of the various types of cities and also the non-urban TTWAs in this respect. Also, private services had comparable share between the three main groups of cities and in the non-urban TTWAs. The exception here is London, in which private services formed a much greater share (51\%), mainly because of a far greater share of Knowledge Intensive Business Services (although transport and logistics also had a larger share than in the national economy). Hence London seemed to have been somewhat better placed to benefit from the structural transformations that were going to occur in the next decades, whereas Groups II and III were at a comparative disadvantage. For the sake of contrast and of completeness, we have included Aberdeen as well in this table.

Figures 5 to 9 show how the relative distribution of broad types of sectors over the groups changed over time, by displaying the development of the location quotients. Agriculture and fishing, coal and other mining, and oil and gas extraction, are excluded as these made up relatively small shares of the British economy, and are moreover activities that mainly take place outside of cities.

London already had relatively low concentrations of manufacturing activity, and these have been falling further over the period. The very high concentrations of output in Knowledge Intensive Business Services have remained high. But interestingly, the relative share declined somewhat over the 1970s before being restored in the 1980s probably because of the cessation of government policy activity designed to disperse office-based activity from London to its surrounding areas. Towards the end of the 1990s, the relative concentration began to fall somewhat again. London has experienced a marked drop in the concentration of output in transport and logistics and the public sector throughout the period.

The cities in the fast-growing Group I had somewhat lower concentrations of manufacturing initially. But they have increased their relative concentration in high tech manufacturing over the period, particularly after the mid-1990s (Figure 6). These cities have noticeably increased their relative concentration in transport and logistics and also Knowledge Intensive Business Services, whilst their share of public service output has gone down.

The cities in Group II, Figure 7, have historically been characterised by relatively greater concentration of textile related activity, which - even though this sector has declined very significantly at the national level - has remained concentrated in these cities. In terms of private services (as well as other types of manufacturing) there seems to be a convergence taking place, in which the cities in Group II increasingly emulate the economic structure of the nation as a whole.

The cities in Group III were historically characterised by a relatively high share of manufacturing, in particular of manufacturing in metal related industries, as is clear from 
Figure 8. This pattern has persisted. As noted manufacturing output has grown only very little over the period, hence there may be an indication that the comparatively high concentrations of manufacturing have contributed to the slow growth of these cities in general. The more fast growing private services remain underrepresented in the cities in Group III, and this is especially true for the Knowledge Intensive Business Services. By contrast, public services seem to have increased their share in these cities considerably

Table 4: Economic structure in groups of cities in 1971, with total GVA in 1971 for broad groups of sectors and for performance types (in million fs, 2011 Current Market Value)

\begin{tabular}{|c|c|c|c|c|c|c|c|c|}
\hline & London & $\begin{array}{l}\text { Group I: } \\
\text { 'Pulling } \\
\text { Ahead' }\end{array}$ & $\begin{array}{c}\text { Group II: } \\
\text { 'Keeping } \\
\text { Pace' }\end{array}$ & $\begin{array}{l}\text { Group III: } \\
\text { 'Falling } \\
\text { Behind' }\end{array}$ & $\begin{array}{l}\text { Non- } \\
\text { urban } \\
\text { TTWAs }\end{array}$ & $\begin{array}{l}\text { Aber- } \\
\text { deen }\end{array}$ & $\begin{array}{l}\text { Great } \\
\text { Britain }\end{array}$ & $\begin{array}{l}\text { Total } \\
\text { GVA } \\
1971\end{array}$ \\
\hline \multicolumn{9}{|l|}{ Broad sector groups } \\
\hline $\begin{array}{l}\text { Agriculture and } \\
\text { fishing }\end{array}$ & $0.2 \%$ & $1.4 \%$ & $0.8 \%$ & $0.7 \%$ & $2.2 \%$ & $3.9 \%$ & $1.0 \%$ & 5,218 \\
\hline $\begin{array}{l}\text { Coal and Other } \\
\text { mining }\end{array}$ & $0.2 \%$ & $0.2 \%$ & $0.4 \%$ & $0.2 \%$ & $1.0 \%$ & $0.0 \%$ & $0.4 \%$ & 2,074 \\
\hline $\begin{array}{l}\text { Oil, Gas and Mining } \\
\text { support }\end{array}$ & $0.3 \%$ & $0.1 \%$ & $0.4 \%$ & $0.1 \%$ & $0.4 \%$ & $0.3 \%$ & $0.3 \%$ & 1,430 \\
\hline Metals and related & $2.1 \%$ & $3.7 \%$ & $3.5 \%$ & $7.4 \%$ & $5.4 \%$ & $1.2 \%$ & $4.4 \%$ & 23,959 \\
\hline Textiles and related & $1.4 \%$ & $1.3 \%$ & $4.1 \%$ & $1.6 \%$ & $2.3 \%$ & $0.9 \%$ & $2.2 \%$ & 12,029 \\
\hline Light manufacturing & $5.3 \%$ & $8.5 \%$ & $8.4 \%$ & $9.5 \%$ & $8.5 \%$ & $16.3 \%$ & $8.1 \%$ & 43,733 \\
\hline $\begin{array}{l}\text { High tech } \\
\text { manufacturing }\end{array}$ & $4.3 \%$ & $8.1 \%$ & $9.2 \%$ & $10.5 \%$ & $5.3 \%$ & $1.7 \%$ & $7.7 \%$ & 41,653 \\
\hline Utilities & $1.1 \%$ & $2.4 \%$ & $3.0 \%$ & $2.8 \%$ & $3.1 \%$ & $4.7 \%$ & $2.5 \%$ & 13,485 \\
\hline Construction & $10.3 \%$ & $10.5 \%$ & $10.7 \%$ & $11.5 \%$ & $11.7 \%$ & $13.2 \%$ & $10.9 \%$ & 59,022 \\
\hline $\begin{array}{l}\text { Transport and } \\
\text { logistics }\end{array}$ & $15.1 \%$ & $12.4 \%$ & $10.7 \%$ & $10.9 \%$ & $10.7 \%$ & $12.2 \%$ & $11.9 \%$ & 64,362 \\
\hline $\begin{array}{l}\text { Retail and personal } \\
\text { services }\end{array}$ & $11.2 \%$ & $13.8 \%$ & $13.5 \%$ & $12.1 \%$ & $14.7 \%$ & $11.2 \%$ & $12.9 \%$ & 69,463 \\
\hline $\begin{array}{l}\text { Knowledge Intensive } \\
\text { Business Services }\end{array}$ & $24.7 \%$ & $9.1 \%$ & $8.6 \%$ & $9.0 \%$ & $7.6 \%$ & $8.7 \%$ & $12.0 \%$ & 64,529 \\
\hline Public services & $23.9 \%$ & $28.3 \%$ & $26.5 \%$ & $23.6 \%$ & $27.1 \%$ & $25.7 \%$ & $25.7 \%$ & 138,334 \\
\hline \multicolumn{9}{|l|}{ Performance types } \\
\hline $\begin{array}{l}\text { GVA below average, } \\
\text { Prod below average. }\end{array}$ & $44.4 \%$ & $44.8 \%$ & $42.6 \%$ & $41.0 \%$ & $47.9 \%$ & $44.7 \%$ & $43.7 \%$ & 235,658 \\
\hline $\begin{array}{l}\text { GVA below average, } \\
\text { Prod above average }\end{array}$ & $16.5 \%$ & $23.4 \%$ & $26.2 \%$ & $31.2 \%$ & $23.6 \%$ & $27.4 \%$ & $24.6 \%$ & 132,637 \\
\hline $\begin{array}{l}\text { GVA above average, } \\
\text { Prod below average }\end{array}$ & $19.8 \%$ & $16.2 \%$ & $15.5 \%$ & $13.9 \%$ & $14.0 \%$ & $12.0 \%$ & $15.9 \%$ & 85,590 \\
\hline $\begin{array}{l}\text { GVA above average, } \\
\text { Prod above average }\end{array}$ & $19.3 \%$ & $15.6 \%$ & $15.7 \%$ & $13.9 \%$ & $14.5 \%$ & $15.8 \%$ & $15.8 \%$ & 85,406 \\
\hline Total GVA 1971 & $\begin{array}{c}111,959 \\
(100.0 \%) \\
\end{array}$ & $\begin{array}{c}84,466 \\
(100.0 \%) \\
\end{array}$ & $\begin{array}{l}133,067 \\
(100.0 \%) \\
\end{array}$ & $\begin{array}{c}130,019 \\
(100.0 \%) \\
\end{array}$ & $\begin{array}{c}76,202 \\
(100.0 \%) \\
\end{array}$ & $\begin{array}{c}3,579 \\
(100.0 \%) \\
\end{array}$ & $\begin{array}{l}539,291 \\
(100.0 \%) \\
\end{array}$ & 539,291 \\
\hline $\begin{array}{l}\text { Share of Group in } \\
1971\end{array}$ & $20.8 \%$ & $15.7 \%$ & $24.7 \%$ & $24.1 \%$ & $14.1 \%$ & $0.7 \%$ & $100.0 \%$ & \\
\hline
\end{tabular}


relative to the nation as a whole. This may have provided something of a compensating development, but an increasing dependence on public services carries its own problems as a basis for sustained high growth over the long term.

Figure 9 makes clear that manufacturing is increasingly concentrated outside of the cities, in less urbanised and rural locations. Knowledge Intensive Business Services still seem to have a clear predilection for cities however, and the concentration of KIBS in more rural parts of the country has remained quite low.

Figure 5: London: Location quotients for broad groups of sectors based on GVA-shares
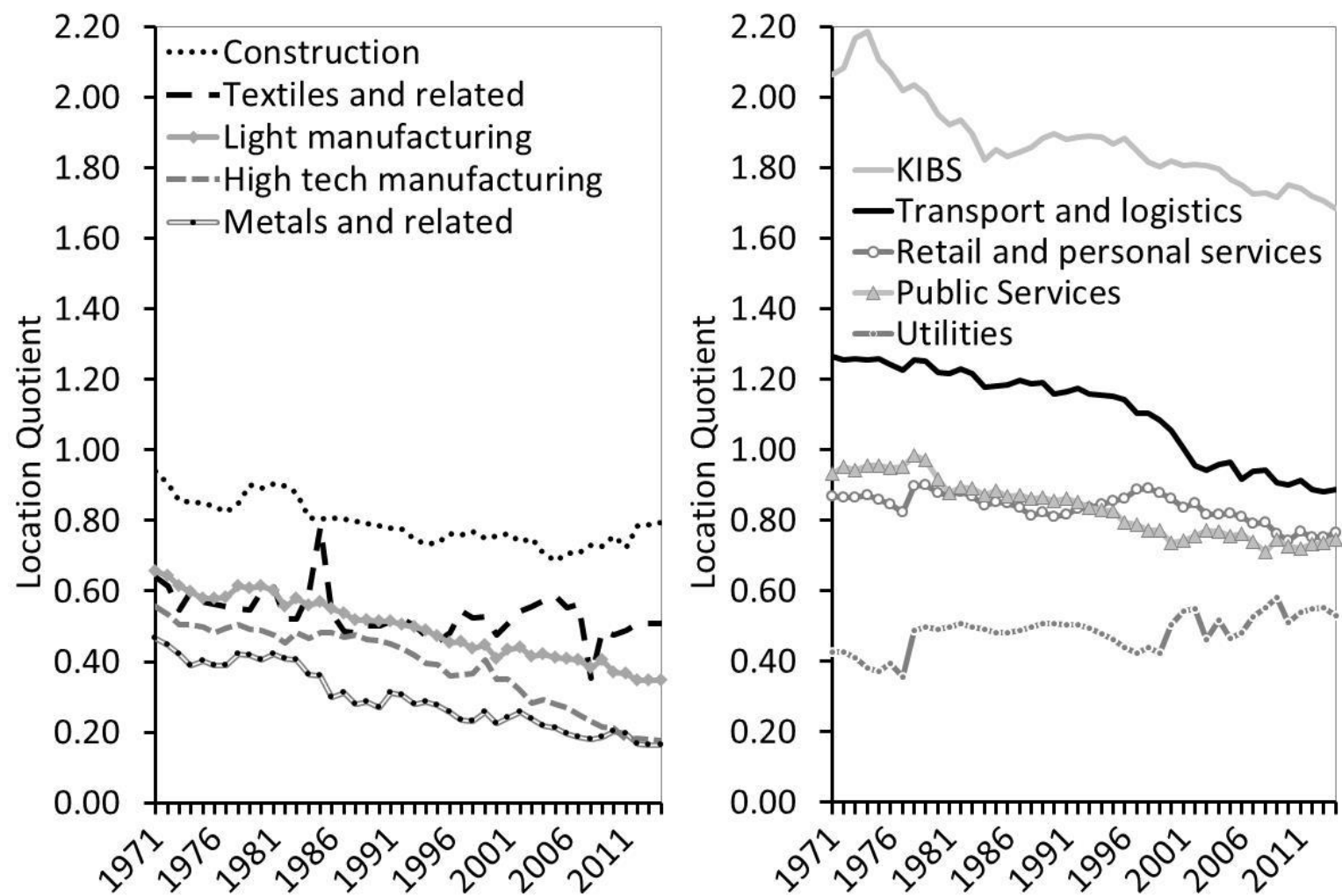
Figure 6: Group I (GVA +): Location quotients for broad groups of sectors based on GVAshares.
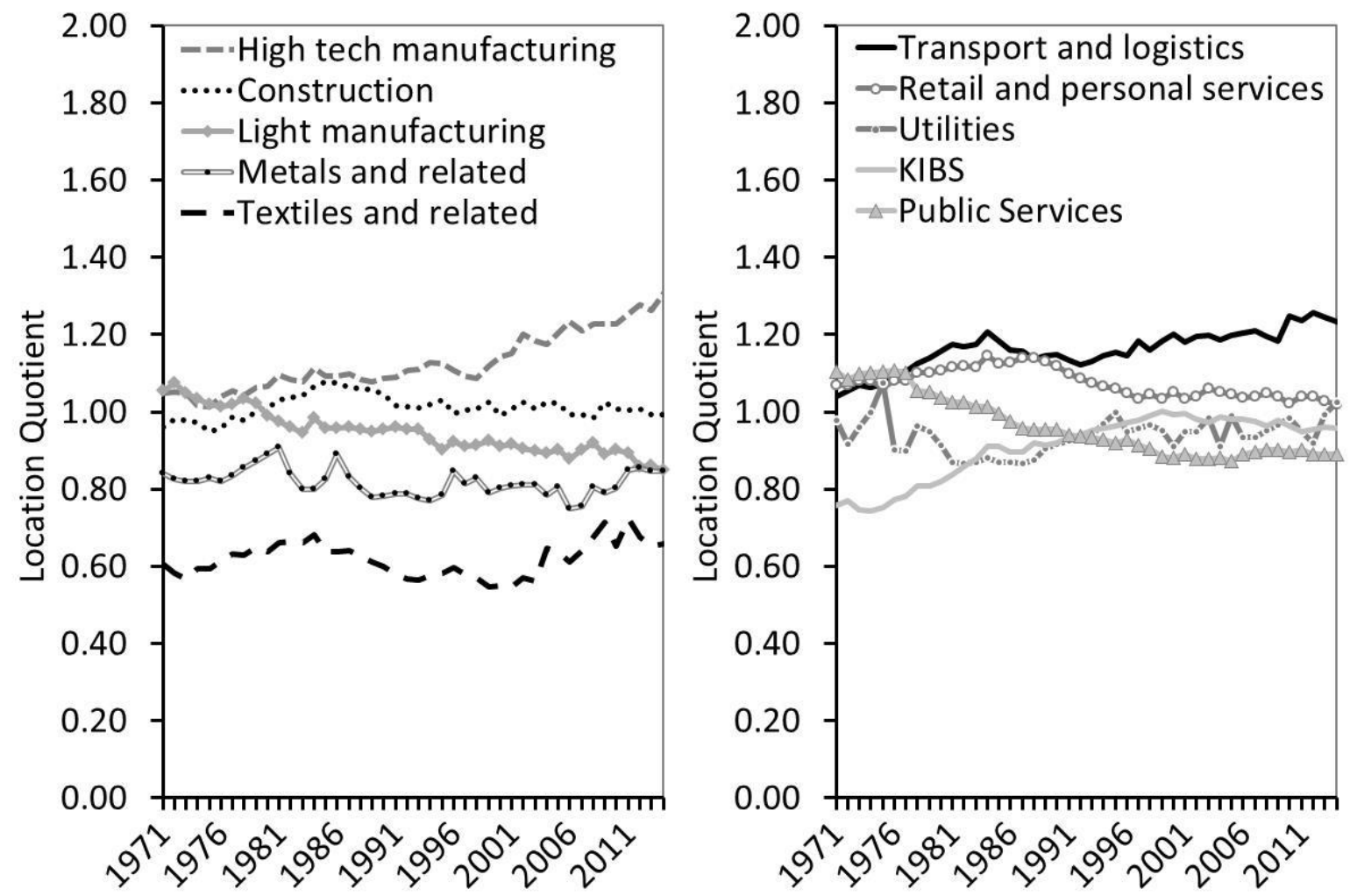

Figure 7: Group II (GVA 0): Location quotients for broad groups of sectors based on GVAshares.
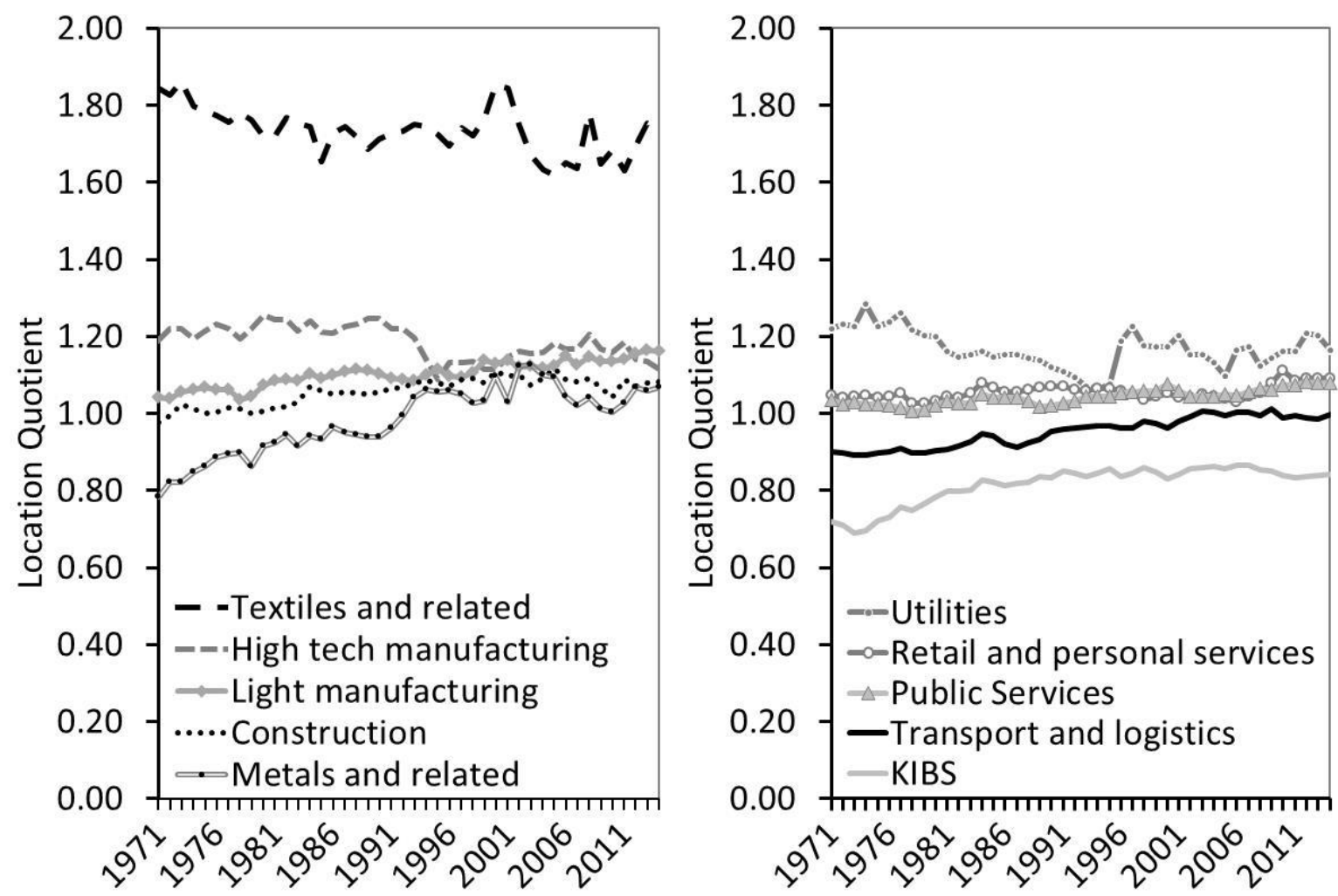
Figure 8: Group III (GVA -): Location quotients for broad groups of sectors based on GVA-shares.
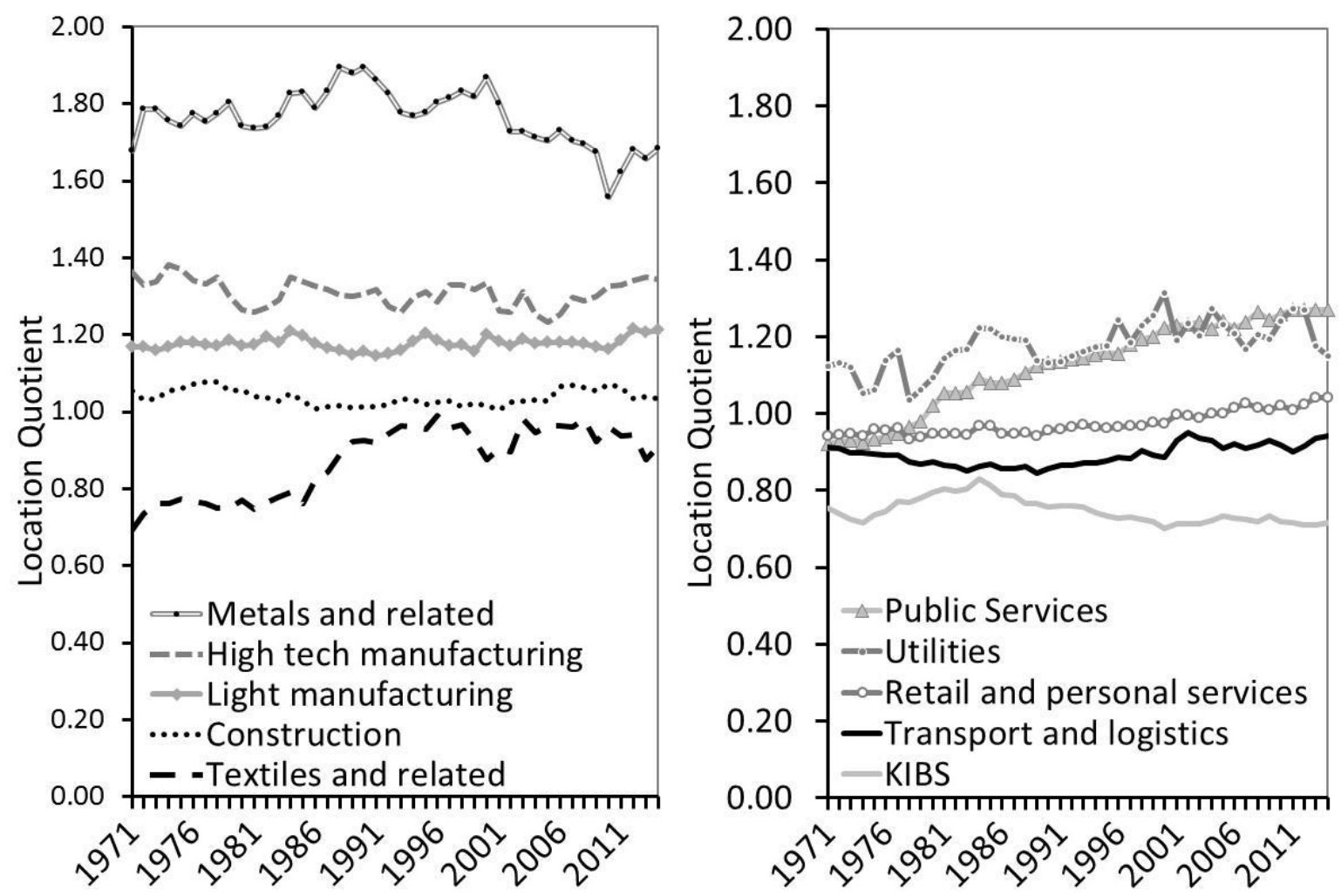

Figure 9: Non-urban TTWAs: Location quotients for broad groups of sectors based on GVA-shares
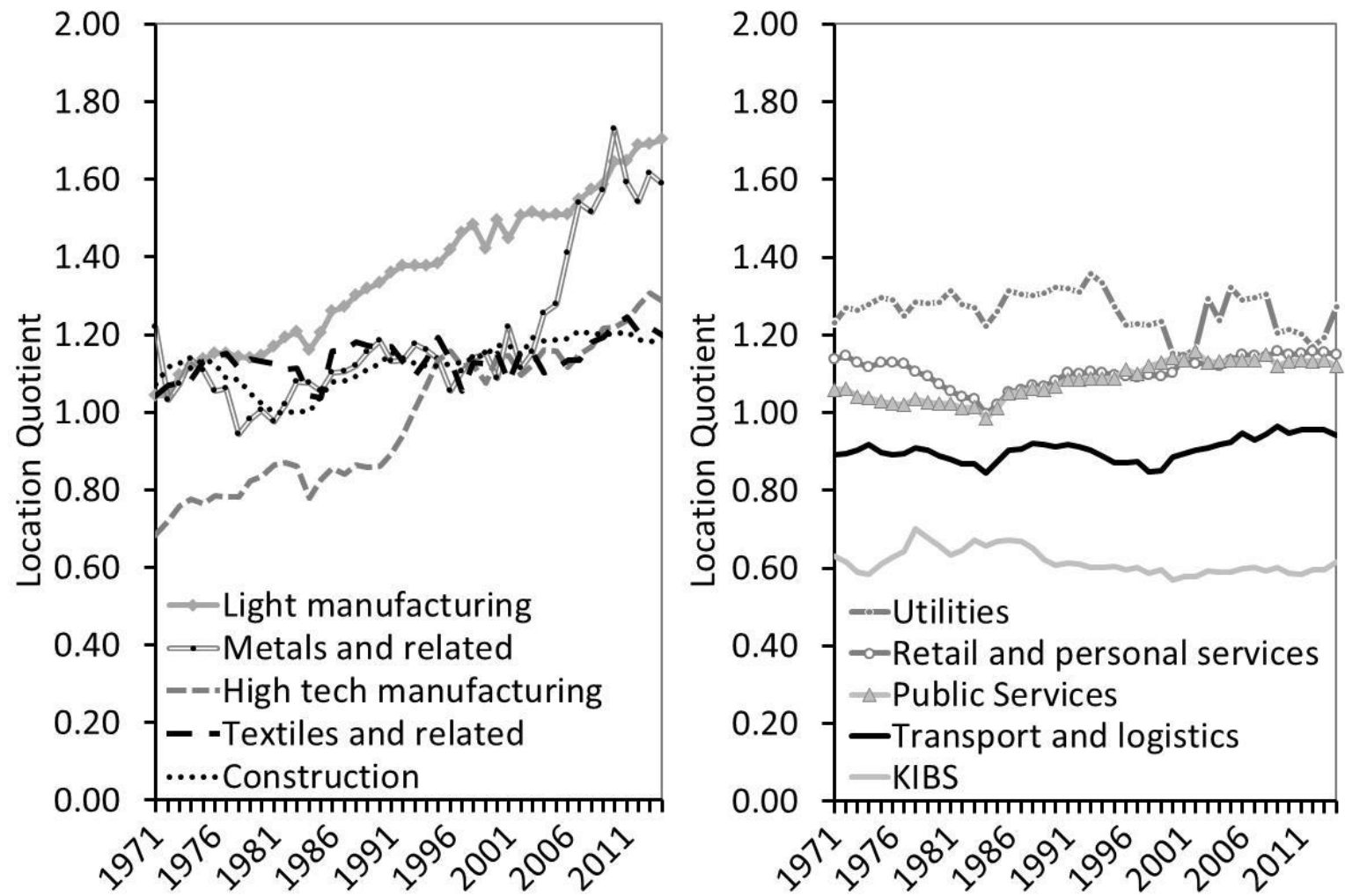
These developments in the geographical distribution of industries over Great Britain are also reflected in the sectoral breakdown of changes in output across the various groups over the period. Table 5 and Table 6 show the breakdown of output change over the period. Table 5 exhibits which sections of the economy experienced negative output change - i.e. decline in output - over the period. At the bottom of the table, the total absolute decline in each of the groups is presented, which is broken down into the percentage contribution of each broad sector group and again of each sector performance type. Table 6 presents a similar breakdown for positive output change - in other words, growth in GVA - and shows the primary sources of growth in each of the groups. Added together the negative change in Table 5 and positive change in Table 6, will represent the overall (net) GVA growth over the period for each group.

With regard to negative output change, it is clear that London and the cities in Group III have had to deal with more decline in their sectors than other parts of the country. In both cases this was due to substantial losses of output in manufacturing, which perhaps also had a further negative effect on transport and logistics. In London, furthermore, public administration and defence have lost output. In Group III, some parts of its metal related industry (in particular basic steel making and manufacture of metal products) and of its high tech manufacturing (especially production of motor vehicles and of machinery) have sustained heavy losses. In Group II the dramatic decline of the textile industry in Britain is clearly noticeable, but other segments in manufacturing have not suffered as much as in Group III and in London.

There have been very large differences in the capacity to generate output growth between the groups over the period. On the one hand, there are the well-performing cities in Group I and London, which have seen a lot of expansion across their economies. On the other hand, there are the poorly performing cities in Group III, which in addition to experiencing more decline in output, have also not been able to generate much output growth compared to other cities. Group II and non-urban TTWAs, have been tracking the national average in this respect. It is also immediately clear from this table that very little growth has come from manufacturing, with the exception perhaps of some parts of high tech manufacturing (mainly pharmaceuticals, production of computers, and of motor vehicles) in Group I and non-urban TTWAs. By far the greatest share of growth in all the groups has been in private services, especially KIBS and to a lesser extent retail and personal services. In London, KIBS account for around two thirds of positive change in output. Also Group I shows a greater increase of output because of growth in KIBS than the other groups. The nature of the growth of KIBS between London and the cities of Group I is somewhat different though; with growth in London more driven by financial services, legal and accounting, and entertainment industries, and Group I more dominated by IT services and real estate activities. Group III is lagging behind somewhat in terms of the share of its growth due to KIBS. Group III by contrast shows 
a much greater share due to expansion of public services, especially health care and education. These developments then also explain the greater share of higher productivity growth activities in the output growth of London and Group I; while in Group III somewhat more of its growth is constituted of sectors with lower productivity growth.

Table 5: Breakdown of negative GVA change (million $\mathrm{fs}, 2011 \mathrm{CMV}$ ), by broad sector groups and performance types for groupss of cities; 1971-2014

\begin{tabular}{|c|c|c|c|c|c|c|c|c|}
\hline & London & $\begin{array}{l}\text { Group I: } \\
\text { 'Pulling } \\
\text { Ahead' }\end{array}$ & $\begin{array}{c}\text { Group II: } \\
\text { 'Keeping } \\
\text { Pace' }\end{array}$ & $\begin{array}{l}\text { Group III: } \\
\text { 'Falling } \\
\text { Behind' }\end{array}$ & $\begin{array}{c}\text { Non- } \\
\text { urban } \\
\text { TTWAs }\end{array}$ & $\begin{array}{l}\text { Aber- } \\
\text { deen }\end{array}$ & $\begin{array}{l}\text { Great } \\
\text { Britain }\end{array}$ & $\begin{array}{c}\text { Total } \\
\text { neg. GVA } \\
\text { change }\end{array}$ \\
\hline \multicolumn{9}{|l|}{ Broad sector groups } \\
\hline $\begin{array}{l}\text { Agriculture and } \\
\text { fishing }\end{array}$ & $0.6 \%$ & & $0.2 \%$ & $0.3 \%$ & & $22.1 \%$ & $0.5 \%$ & -171 \\
\hline $\begin{array}{l}\text { Coal and Other } \\
\text { mining }\end{array}$ & $1.4 \%$ & $1.4 \%$ & $6.3 \%$ & $0.9 \%$ & $7.4 \%$ & & $2.7 \%$ & -973 \\
\hline $\begin{array}{l}\text { Oil, Gas and Mining } \\
\text { support }\end{array}$ & & & $7.2 \%$ & $1.0 \%$ & $0.5 \%$ & & $1.9 \%$ & -672 \\
\hline Metals and related & $16.6 \%$ & $25.5 \%$ & $11.1 \%$ & $33.4 \%$ & $50.9 \%$ & $6.5 \%$ & $24.9 \%$ & $-8,860$ \\
\hline Textiles and related & $11.3 \%$ & $27.2 \%$ & $51.3 \%$ & $10.5 \%$ & $35.8 \%$ & $6.1 \%$ & $22.2 \%$ & $-7,917$ \\
\hline Light manufacturing & $21.1 \%$ & $20.0 \%$ & $7.2 \%$ & $12.7 \%$ & $2.7 \%$ & $56.9 \%$ & $13.9 \%$ & $-4,944$ \\
\hline $\begin{array}{l}\text { High tech } \\
\text { manufacturing }\end{array}$ & $28.1 \%$ & $7.6 \%$ & $7.3 \%$ & $28.5 \%$ & & & $20.1 \%$ & $-7,173$ \\
\hline Utilities & $3.4 \%$ & $18.4 \%$ & $9.4 \%$ & $6.9 \%$ & $2.7 \%$ & & $6.7 \%$ & $-2,395$ \\
\hline Construction & & & & & & & & 0 \\
\hline $\begin{array}{l}\text { Transport and } \\
\text { logistics }\end{array}$ & $9.2 \%$ & & & $5.8 \%$ & & & $4.7 \%$ & $-1,659$ \\
\hline $\begin{array}{l}\text { Retail and personal } \\
\text { services }\end{array}$ & & & & & & & & 0 \\
\hline $\begin{array}{l}\text { Knowledge Intensive } \\
\text { Business Services }\end{array}$ & & & & & & $8.4 \%$ & $0.1 \%$ & -25 \\
\hline Public services & $8.3 \%$ & & & & & & $2.3 \%$ & -822 \\
\hline \multicolumn{9}{|l|}{ Performance types } \\
\hline $\begin{array}{l}\text { GVA below average, } \\
\text { Prod below average. }\end{array}$ & $14.5 \%$ & $18.4 \%$ & $9.8 \%$ & $9.1 \%$ & $41.5 \%$ & $6.5 \%$ & $14.0 \%$ & $-4,981$ \\
\hline $\begin{array}{l}\text { GVA below average, } \\
\text { Prod above average }\end{array}$ & $85.5 \%$ & $81.6 \%$ & $82.9 \%$ & $89.9 \%$ & $58.0 \%$ & $82.5 \%$ & $84.0 \%$ & $-29,914$ \\
\hline $\begin{array}{l}\text { GVA above average, } \\
\text { Prod below average }\end{array}$ & & & $0.2 \%$ & & & & $0.0 \%$ & -12 \\
\hline $\begin{array}{l}\text { GVA above average, } \\
\text { Prod above average }\end{array}$ & & & $7.2 \%$ & $1.0 \%$ & $0.5 \%$ & $11.0 \%$ & $2.0 \%$ & -704 \\
\hline $\begin{array}{l}\text { Total negative GVA } \\
\text { change }\end{array}$ & $\begin{array}{l}-9,928 \\
(100.0) \\
\end{array}$ & $\begin{array}{c}-2,169 \\
(100.0 \%) \\
\end{array}$ & $\begin{array}{c}-7,364 \\
(100.0 \%) \\
\end{array}$ & $\begin{array}{l}-12,889 \\
(100.0 \%) \\
\end{array}$ & $\begin{array}{c}-2,963 \\
(100.0 \%) \\
\end{array}$ & $\begin{array}{c}-298 \\
(100.0 \%) \\
\end{array}$ & $\begin{array}{c}-35,611 \\
(100.0 \%) \\
\end{array}$ & $-35,611$ \\
\hline GVA in 1971 & 111,959 & 84,466 & 133,067 & 130,019 & 76,202 & 3,579 & 539,291 & \\
\hline $\begin{array}{l}\text { Negative GVA-change } \\
\text { as \% of GVA in } 1971\end{array}$ & $-8.9 \%$ & $-2.6 \%$ & $-5.5 \%$ & $-9.9 \%$ & $-3.9 \%$ & $-8.3 \%$ & $-6.6 \%$ & \\
\hline
\end{tabular}


Table 6: Breakdown of positive GVA change (million $\mathrm{fs}, 2011 \mathrm{CMV}$ ), by broad sector groups and performance types for clubs of cities; 1971-2014

\begin{tabular}{|c|c|c|c|c|c|c|c|c|}
\hline & London & $\begin{array}{l}\text { Group I: } \\
\text { 'Pulling } \\
\text { Ahead' }\end{array}$ & $\begin{array}{c}\text { Group II: } \\
\text { 'Keeping } \\
\text { Pace' }\end{array}$ & $\begin{array}{l}\text { Group III: } \\
\text { 'Falling } \\
\text { Behind' }\end{array}$ & $\begin{array}{c}\text { Non- } \\
\text { urban } \\
\text { TTWAs }\end{array}$ & $\begin{array}{l}\text { Aber- } \\
\text { deen }\end{array}$ & $\begin{array}{l}\text { Great } \\
\text { Britain }\end{array}$ & $\begin{array}{c}\text { Total } \\
\text { pos. GVA } \\
\text { change }\end{array}$ \\
\hline \multicolumn{9}{|l|}{ Broad sector groups } \\
\hline $\begin{array}{l}\text { Agriculture and } \\
\text { fishing }\end{array}$ & & $0.5 \%$ & $0.3 \%$ & $0.2 \%$ & $1.2 \%$ & & $0.4 \%$ & 3,229 \\
\hline $\begin{array}{l}\text { Coal and Other } \\
\text { mining }\end{array}$ & $0.1 \%$ & $0.1 \%$ & $0.1 \%$ & & & $0.3 \%$ & $0.1 \%$ & 488 \\
\hline $\begin{array}{l}\text { Oil, Gas and Mining } \\
\text { support }\end{array}$ & $0.1 \%$ & $0.3 \%$ & & & $0.1 \%$ & $32.0 \%$ & $0.6 \%$ & 4,975 \\
\hline Metals and related & & $0.3 \%$ & $0.4 \%$ & & $1.2 \%$ & $1.3 \%$ & $0.3 \%$ & 2,882 \\
\hline Textiles and related & & & & & & $0.0 \%$ & $0.0 \%$ & 4 \\
\hline Light manufacturing & $0.2 \%$ & $1.4 \%$ & $2.2 \%$ & $0.9 \%$ & $5.8 \%$ & $2.4 \%$ & $1.9 \%$ & 15,780 \\
\hline $\begin{array}{l}\text { High tech } \\
\text { manufacturing }\end{array}$ & $0.3 \%$ & $5.8 \%$ & $3.1 \%$ & $4.8 \%$ & $6.9 \%$ & $3.0 \%$ & $3.8 \%$ & 32,190 \\
\hline Utilities & $1.4 \%$ & $2.5 \%$ & $2.6 \%$ & $2.9 \%$ & $2.8 \%$ & $0.9 \%$ & $2.3 \%$ & 19,506 \\
\hline Construction & $2.2 \%$ & $4.7 \%$ & $4.5 \%$ & $1.1 \%$ & $5.1 \%$ & $2.0 \%$ & $3.6 \%$ & 29,984 \\
\hline $\begin{array}{l}\text { Transport and } \\
\text { logistics }\end{array}$ & $7.2 \%$ & $14.5 \%$ & $11.2 \%$ & $9.9 \%$ & $10.4 \%$ & $8.7 \%$ & $10.7 \%$ & 89,726 \\
\hline $\begin{array}{l}\text { Retail and personal } \\
\text { services }\end{array}$ & $12.4 \%$ & $17.5 \%$ & $19.8 \%$ & $20.1 \%$ & $20.6 \%$ & $15.0 \%$ & $17.6 \%$ & 148,014 \\
\hline $\begin{array}{l}\text { Knowledge Intensive } \\
\text { Business Services }\end{array}$ & $66.0 \%$ & $39.1 \%$ & $37.8 \%$ & $34.6 \%$ & $26.3 \%$ & $25.7 \%$ & $42.6 \%$ & 358,813 \\
\hline Public services & $10.0 \%$ & $13.3 \%$ & $18.0 \%$ & $25.4 \%$ & $19.5 \%$ & $8.7 \%$ & $16.2 \%$ & 136,100 \\
\hline \multicolumn{9}{|l|}{ Performance types } \\
\hline $\begin{array}{l}\text { GVA below average, } \\
\text { Prod below average. }\end{array}$ & $13.2 \%$ & $18.5 \%$ & $18.5 \%$ & $15.8 \%$ & $19.6 \%$ & $11.3 \%$ & $16.9 \%$ & 142,168 \\
\hline $\begin{array}{l}\text { GVA below average, } \\
\text { Prod above average }\end{array}$ & $1.4 \%$ & $7.3 \%$ & $6.4 \%$ & $3.5 \%$ & $13.1 \%$ & $7.0 \%$ & $5.9 \%$ & 49,959 \\
\hline $\begin{array}{l}\text { GVA above average, } \\
\text { Prod below average }\end{array}$ & $42.6 \%$ & $34.7 \%$ & $39.6 \%$ & $43.8 \%$ & $35.9 \%$ & $26.0 \%$ & $39.1 \%$ & 328,999 \\
\hline $\begin{array}{l}\text { GVA above average, } \\
\text { Prod above average }\end{array}$ & $42.8 \%$ & $39.4 \%$ & $35.5 \%$ & $37.0 \%$ & $31.4 \%$ & $55.7 \%$ & $38.1 \%$ & 320,565 \\
\hline $\begin{array}{l}\text { Total positive GVA } \\
\text { change }\end{array}$ & $\begin{array}{l}203,378 \\
(100.0 \%)\end{array}$ & $\begin{array}{l}190,442 \\
(100.0 \%)\end{array}$ & $\begin{array}{l}192,694 \\
(100.0 \%)\end{array}$ & $\begin{array}{l}121,695 \\
(100.0 \%)\end{array}$ & $\begin{array}{l}121,239 \\
(100.0 \%)\end{array}$ & $\begin{array}{c}12,243 \\
(100.0 \%)\end{array}$ & $\begin{array}{l}841,691 \\
(100.0 \%)\end{array}$ & 841,691 \\
\hline GVA in 1971 & 111,959 & 84,466 & 133,067 & 130,019 & 76,202 & 3,579 & 539,291 & \\
\hline $\begin{array}{l}\text { Positive GVA-change } \\
\text { as \% of GVA in } 1971\end{array}$ & $181.7 \%$ & $225.5 \%$ & $144.8 \%$ & $93.6 \%$ & $159.1 \%$ & $342.1 \%$ & $156.1 \%$ & \\
\hline
\end{tabular}

\section{Contribution of Structural Factors to the Growth of British Cities}

The foregoing analysis would seem to suggest that output growth in cities has been strongly influenced by their initial sectoral structure and how that structure then changes over time; in other words, economic structure would appear to be a key determinant of city output growth. However, the performance of sectors is not uniform throughout the country, and thus the growth of cities may be importantly affected by sectors doing significantly better or worse in some cities than would be expected based on their national performance. The 
expansion or decline of some sectors can thus be concentrated in some cities while bypassing others. Hence a city's structural ensemble and how that ensemble changes over time will only partially explain the growth of cities. Other factors will be important, such as differences in levels of innovation and entrepreneurship, as well as the geographical spread of the types of functions within sectors (head offices, $R \& D$, administration, production, etc.). These differences may in turn reflect local advantages in terms of human capital, agglomeration, policy, proximity to London and governance, etc. (Martin et al., 2016a). To explore the relative contribution of structural versus other, city-specific 'competitiveness' factors, we use a dynamic shift share analysis.

Shift share has been used extensively and there is a large literature discussing its application and relative strengths and weaknesses. Prominent amongst the literature is the work of Fothergill and Gudgin (1984), Selting and Loveridge (1990, 1992) and Loveridge and Selting (1998). A standard criticism is that the choice of weights used to represent the structural base influence the results. In an attempt to overcome this research has relied on dynamic versions that have the advantage over conventional models of allowing both growth rates and economic structure to change, rather than being pivoted on a set of weights at a particular point in time. Examples of this approach include Barff and Knight (1988), Chern et al. (2002) and Fritz and Streicher (2005). More recently, attention has been focused on incorporating regression analysis into shift share, with examples including Blien et al. (2013).

We adopted the dynamic shift share decomposition procedure as used in Gardiner et al. (2013). This has the advantage of recording and updating the levels of sectoral composition and the changes within this on an annual basis, so the point of reference to distinguish between structural effects and local city-specific effects is allowed to shift over time. It also provides additional information on dynamic transition, which could not be obtained from the standard comparative-static shift-share method. The analysis has been conducted at an 81 sectoral level.

The classic shift-share approach decomposes temporal change in a variable into three additive effects:

(i) National component (NC) the change that would occur if all regions' sectors grow at national rate

(ii) Structure effect (SE)

the change that would occur if all regions' sectors grow at national sector rate (minus, or conditional on, the national share effect)

(iii) Local effect (LE)

the difference between the actual change and the sum of national and industry shifts, i.e. a residual designed to capture local-specific factors such as competitiveness, concentration of higher value functions, local policy, etc. 
More formally, if we consider a variable $X$, defined over industry $i$, region $r$ and time $t, a$ temporal change between time $t$ and $t+n$ can be written as:

$$
X_{i r}^{t+n}-X_{i r}^{t}=\Delta X_{i r}^{t+n}=N C_{i r}^{t+n}+S E_{i r}^{t+n}+L E_{i r}^{t+n}
$$

Each of these three components can be expressed as follows:

$$
\begin{aligned}
& N C_{i j}=X_{i j} * g_{n} \\
& S E_{i j}=X_{i j} *\left(g_{i n}-g_{n}\right) \\
& L E_{i j}=X_{i j} *\left(g_{i r}-g_{i n}\right)
\end{aligned}
$$

Where:

$\mathrm{g}=$ the growth of the variable $\mathrm{X}$ over the pre-defined time period (between $\mathrm{t}+\mathrm{n}$ and $\mathrm{t}$ );

$\mathrm{g}_{\mathrm{n}}=$ the national (percentage) growth of variable $X$ during this period,

$\mathrm{g}_{\text {in }}=$ the national (percentage) growth by industry $\mathrm{i}$ of variable $X$ during this period; and

$\mathrm{g}_{\mathrm{ir}}=$ the regional (percentage) growth by industry $\mathrm{i}$ of variable $\mathrm{X}$ during this period.

By summing over all industries in any given city, we arrive at the overall national, industrial mix and residual shift components:

$$
N C_{j}^{t+n}=\sum_{i} X_{i j}^{t} * g_{n} \quad S E_{j}^{t+n}=\sum_{i} X_{i j}^{t} *\left(g_{i n}-g_{n}\right) \quad L E_{j}^{t+n}=\sum_{i} X_{i j}^{t} *\left(g_{i j}-g_{i n}\right)
$$

Using the dynamic version of the technique, and thus decomposing city changes in output on a year-by-year basis, we were able to investigate the contribution that changes in economic structure have made to each city Group's output growth differential over time. This differential growth already incorporates the national component, hence we focus on the contribution of the structure effect and local effect to the positive or negative gap in performance compared to national growth. Moreover, in order to see how matters evolve over the study period, we can track the relative contributions of the structure effect and local effect in the cumulative development of this gap over time. Figure 10 shows the results.

The findings in the case of London are clear. Throughout the period, London benefited from its particular economic structure; that is to say, London has benefited from having a high proportion of nationally fast growing sectors. However, London has certainly not managed to benefit as much as expected, as the structure effect was offset by a negative local effect, which held on persistently over many years until the mid-1990s. But in recent years this local effect has become strongly positive, making up for much of the accumulated losses with regard to the potential growth of London in the decades before (see Figure 2).

The structural effect also appears substantial in explaining the slow growth of the cities in Group III. Throughout the period, these cities have been at a disadvantage because of the composition of their economies, and especially until the mid 1980s this appears to explain about half of the negative gap in output growth with the nation as a whole. However, the negative impact of the local effect has been at least as large, and has only increased over time 
compared to the structural effect. This means that cites in this Group have not only lagged because they have an unfavourable mix of sectors, but that in general those sectors underperform compared to the performance of the sectors for the nation as a whole. This suggests that the various factors that influence a city's overall competitiveness have become increasingly unfavourable.

Group II and the non-urban TTWAs also had to cope with negative impacts of their industrial structure over the period, especially after the early 1980s. But these cities and non-urban TTWAs managed to compensate for this negative structure effect through a positive local effect for most of the period. Hence the performance of the sectors that are present in these locations has on the whole been better than expected.

The strong growth of the Group I cities has almost entirely been due to highly positive local effects: the sectors in these cities have strongly outperformed the national average trends in those sectors. Only from the mid-1990s onwards does a modest positive structure effect emerge, as a result of a higher concentration of high-growth sectors. But the local effect clearly dominates, and seems to reflect a growing competitive advantage of these cities compared to other parts of Great Britain, although this advantage seems to have stabilised following the onset of the financial crisis in 2008.

Figure 10. The contribution of economic structure and of local factors to differential output growth relative the GB across the City Groups, in GVA (billion fs, 2011 CMV) based on 81 sectors

\section{London}

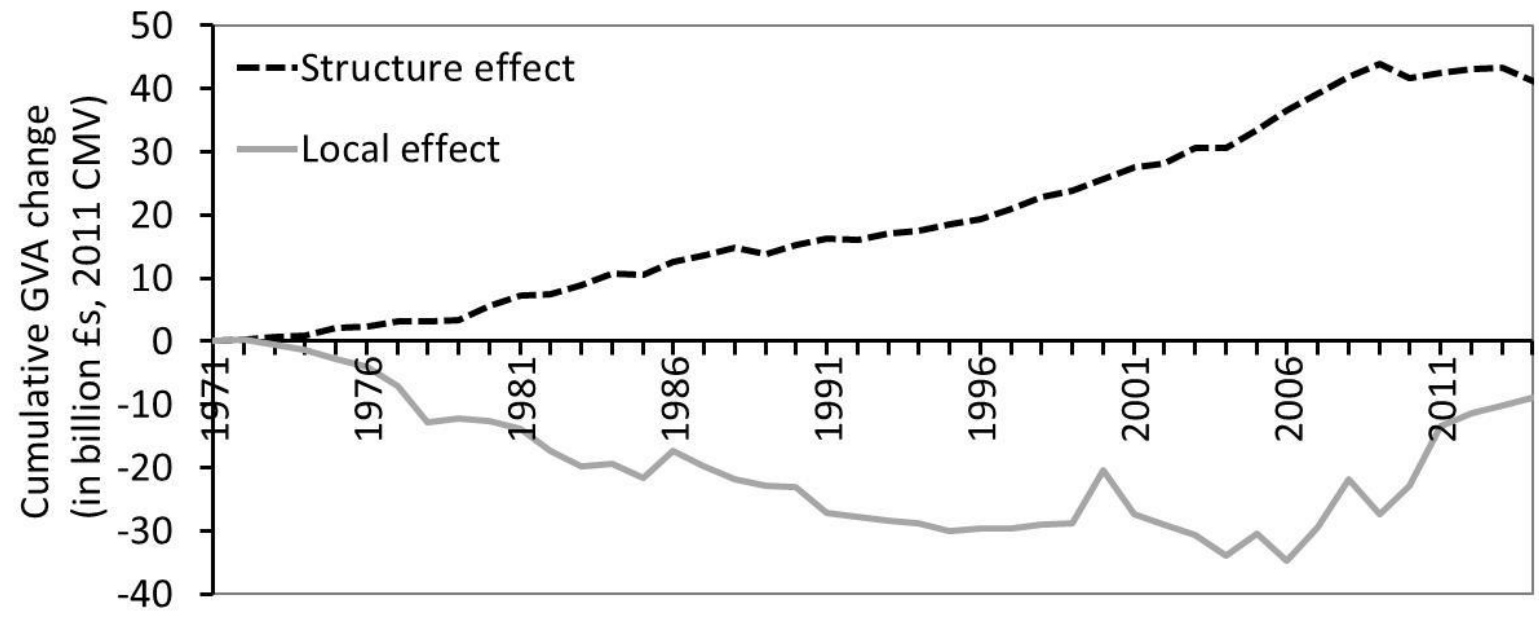


Group I

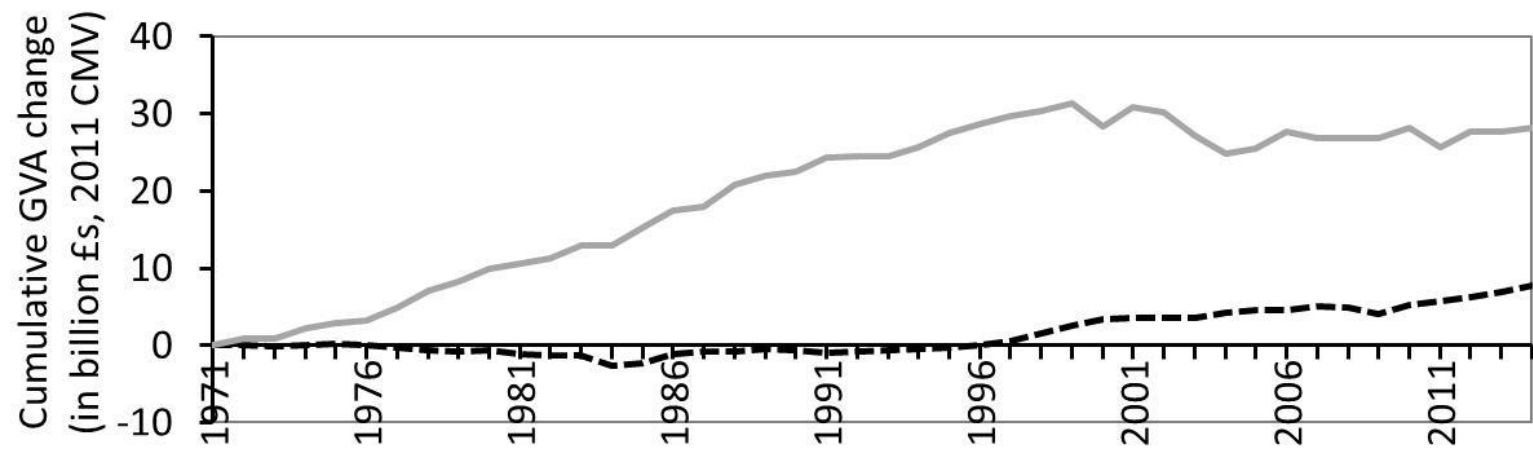

Group II

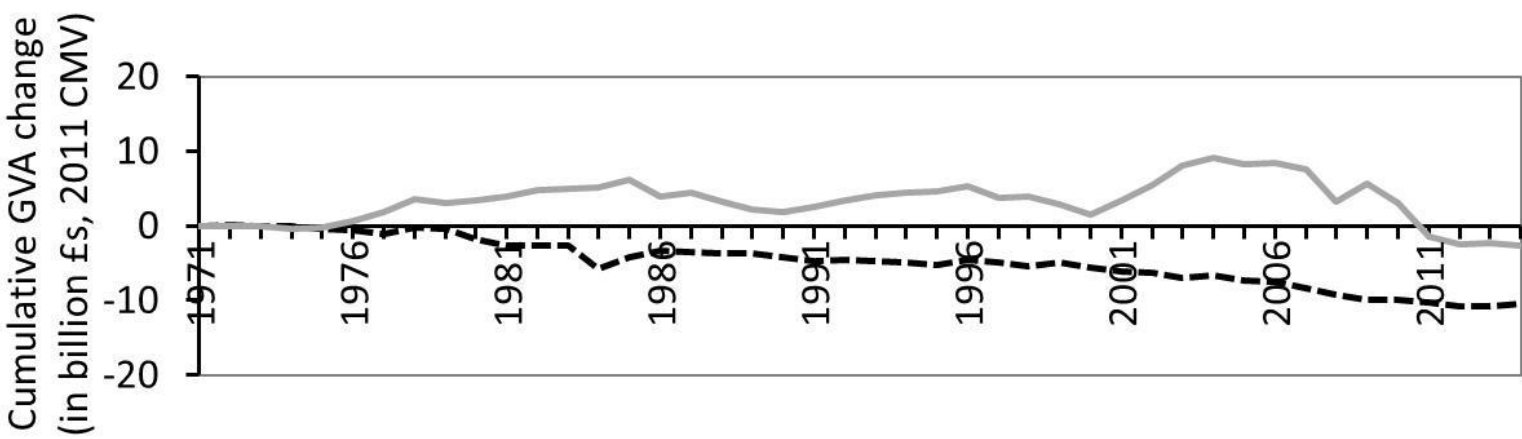

Group III

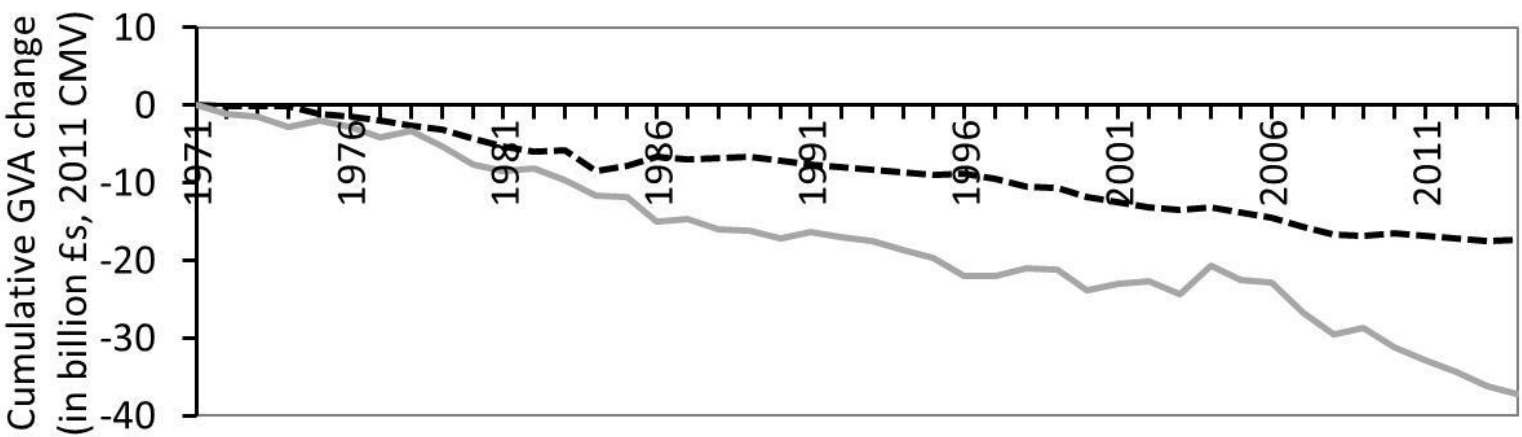

Non-Urban

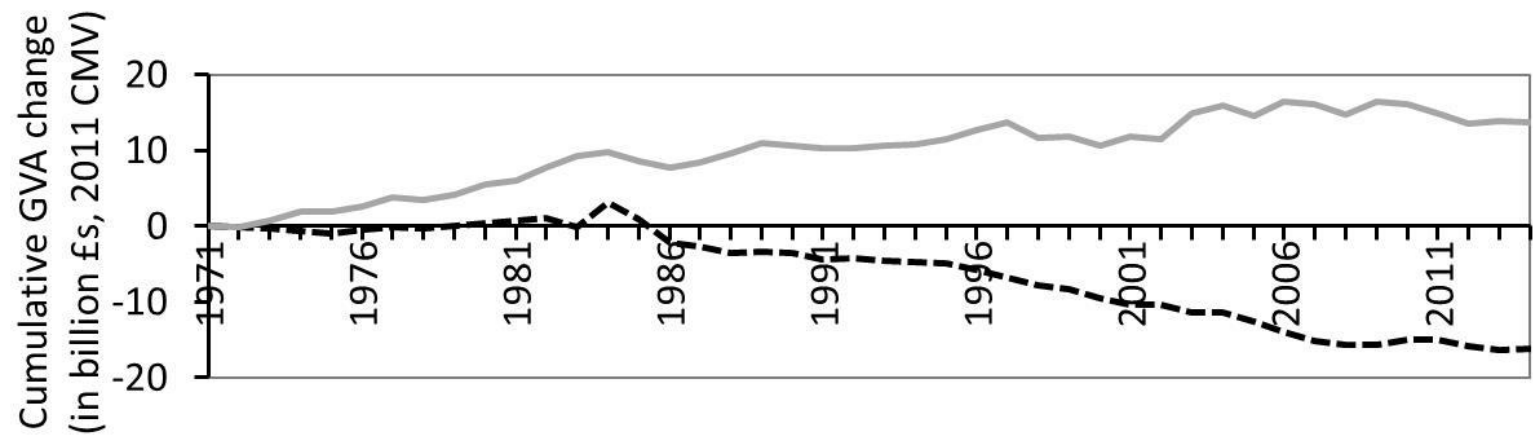




\section{Implications of Structural Transformation in British Cities for Employment}

Thus while structural transformation goes some way in accounting for the observed patterns of output growth across cities, a full explanation would need to examine the host of factors and processes that are subsumed under the 'local effect' identified above. This is beyond the scope of this present paper but factors that are relevant here are local supply effects that affect the ability of areas to adapt to change, as well as factors that enhance an areas competitive advantage like proximity to London and thus market opportunity.

Also of interest are the implications of the patterns of output growth, for city employment trends. As we saw in Figure 1, there is a reasonably close correlation between output growth and employment growth across British cities. Tables 7 and 8 explore this relationship further, and show the breakdown of employment changes in the city groups across broad sector groups and across sector performance types. The general picture is very similar to the one painted in section 5 (in terms of GVA), with the same patterns of growth and decline in the various Groups and sectors. But much more than when examining output, the churn between and within different segments of the economy comes into view. From an employment perspective, the scale of the process of structural transformation over the past five decades is quite remarkable. Even within parts of the economy which exhibit substantial growth of output - such as transport and logistics, public services, utilities, and to a much lesser extent KIBS (with some job loss in insurance and pensions) - considerable movements take place, which are not visible when looking at changes in GVA alone.

Also the uneven effects of the process of structural transformation need to be highlighted. The decline in employment due to job loss in various sectors (especially in manufacturing), seems to have been particularly large in Group III, London, and Group II. But then London and Group II (and furthemore the non-urban TTWAs) seemed to have gained a lot of new employment in other other sectors (mainly services), following the national pattern in this respect. Employment in Group I clearly grew a lot faster than the average. Group III however has, by 2014 , not even fully recovered from the losses of employment it sustained already in the 1970 s and 1980s.

The focus on employment moreover further highlights differences in productivity across sectors, and also across cities. Those sectors where there has been relatively favourable output and productivity growth, compared to the nation, mainly most of the KIBS, are of particular interest. About $40 \%$ of the growth in output in Great Britain over the period from 1971 until 2014 has come from these sectors, yet they have contributed less than $20 \%$ of the growth in employment. By far the most employment growth has been in sectors which have indeed also grown relatively fast in output, but in which the increase of output per job labour productivity - has been below average (such as personal services, health and social care, and warehousing). The remaining source of employment growth has been in sectors which have experienced low output growth and consequently also low productivity growth (such as education, construction, and accommodation and leisure). 
Moreover, the geographical distribution of the growth of high value-added employment across the cities is again quite uneven, being concentrated in Group I and London. In contrast, they have only constituted a small part of employment growth of the cities in Group III, in which employment gains have instead consisted disproportionally of jobs in sectors which have experienced below average growth in productivity. Thus, structural transformation in the British economy also seems reflected in divergent growth of productivity across cities, and thus ultimately real incomes. The divergent development of productivity across British cities - a critical issue attracting increasing attention from the UK Government in relation to its new Industrial Strategy (HM Treasury, 2017) - is examined in Martin et al. (2017). 
Table 7: Breakdown of negative employment change, by broad sector groups and performance types for groups of cities; 1971-2014

\begin{tabular}{|c|c|c|c|c|c|c|c|}
\hline & London & $\begin{array}{l}\text { Group I: } \\
\text { 'Pulling } \\
\text { Ahead' }\end{array}$ & $\begin{array}{l}\text { Group II: } \\
\text { 'Keeping } \\
\text { Pace' }\end{array}$ & $\begin{array}{l}\text { Group III: } \\
\text { 'Falling } \\
\text { Behind' }\end{array}$ & $\begin{array}{l}\text { Non-urban } \\
\text { TTWAs }\end{array}$ & Aberdeen & $\begin{array}{l}\text { Great } \\
\text { Britain }\end{array}$ \\
\hline \multicolumn{8}{|l|}{ Broad sector groups } \\
\hline $\begin{array}{l}\text { Agriculture and } \\
\text { fishing }\end{array}$ & $\begin{array}{l}-7,612 \\
(0.6 \%)\end{array}$ & $\begin{array}{c}-53,847 \\
(6.5 \%)\end{array}$ & $\begin{array}{c}-82,352 \\
(4.5 \%)\end{array}$ & $\begin{array}{c}-50,453 \\
(2.3 \%) \\
\end{array}$ & $\begin{array}{l}-88,113 \\
(13.5 \%)\end{array}$ & $\begin{array}{l}-9,369 \\
(23.1 \%)\end{array}$ & $\begin{array}{c}-291,746 \\
(4.3 \%)\end{array}$ \\
\hline $\begin{array}{l}\text { Coal and Other } \\
\text { mining }\end{array}$ & $\begin{array}{l}-4,443 \\
(0.4 \%) \\
\end{array}$ & $\begin{array}{c}-20,452 \\
(2.5 \%) \\
\end{array}$ & $\begin{array}{l}-63,159 \\
(3.4 \%) \\
\end{array}$ & $\begin{array}{c}-43,264 \\
(2.0 \%) \\
\end{array}$ & $\begin{array}{l}-56,746 \\
(8.7 \%) \\
\end{array}$ & $\begin{array}{c}-2 \\
(0.0 \%) \\
\end{array}$ & $\begin{array}{c}-188,066 \\
(2.8 \%) \\
\end{array}$ \\
\hline $\begin{array}{l}\text { Oil, Gas and Mining } \\
\text { support }\end{array}$ & $\begin{array}{l}-3,872 \\
(0.3 \%) \\
\end{array}$ & $\begin{array}{l}-6,366 \\
(0.8 \%) \\
\end{array}$ & $\begin{array}{c}-31,055 \\
(1.7 \%) \\
\end{array}$ & $\begin{array}{c}-30,216 \\
(1.4 \%) \\
\end{array}$ & $\begin{array}{l}-33,415 \\
(5.1 \%) \\
\end{array}$ & & $\begin{array}{c}-104,924 \\
(1.5 \%) \\
\end{array}$ \\
\hline Metals and related & $\begin{array}{c}-86,087 \\
(6.8 \%) \\
\end{array}$ & $\begin{array}{c}-105,851 \\
(12.8 \%) \\
\end{array}$ & $\begin{array}{c}-177,467 \\
(9.6 \%) \\
\end{array}$ & $\begin{array}{c}-492,408 \\
(22.7 \%) \\
\end{array}$ & $\begin{array}{l}-78,834 \\
(12.0 \%) \\
\end{array}$ & $\begin{array}{c}-281 \\
(0.7 \%) \\
\end{array}$ & $\begin{array}{c}-940,928 \\
(13.8 \%) \\
\end{array}$ \\
\hline Textiles and related & $\begin{array}{c}-69,172 \\
(5.5 \%) \\
\end{array}$ & $\begin{array}{c}-76,772 \\
(9.2 \%) \\
\end{array}$ & $\begin{array}{l}-504,546 \\
(27.3 \%) \\
\end{array}$ & $\begin{array}{c}-173,599 \\
(8.0 \%) \\
\end{array}$ & $\begin{array}{c}-138,716 \\
(21.2 \%) \\
\end{array}$ & $\begin{array}{l}-4,593 \\
(11.3 \%) \\
\end{array}$ & $\begin{array}{c}-967,398 \\
(14.2 \%) \\
\end{array}$ \\
\hline Light manufacturing & $\begin{array}{c}-205,669 \\
(16.3 \%) \\
\end{array}$ & $\begin{array}{c}-208,146 \\
(25.1 \%) \\
\end{array}$ & $\begin{array}{c}-344,002 \\
(18.6 \%) \\
\end{array}$ & $\begin{array}{c}-514,838 \\
(23.7 \%) \\
\end{array}$ & $\begin{array}{l}-75,315 \\
(11.5 \%) \\
\end{array}$ & $\begin{array}{l}-21,574 \\
(53.1 \%) \\
\end{array}$ & $\begin{array}{c}-1,369,544 \\
(20.1 \%) \\
\end{array}$ \\
\hline $\begin{array}{l}\text { High tech } \\
\text { manufacturing }\end{array}$ & $\begin{array}{c}-358,618 \\
(28.4 \%) \\
\end{array}$ & $\begin{array}{l}-235,059 \\
(28.3 \%) \\
\end{array}$ & $\begin{array}{c}-429,749 \\
(23.2 \%) \\
\end{array}$ & $\begin{array}{l}-520,908 \\
(24.0 \%) \\
\end{array}$ & $\begin{array}{l}-78,246 \\
(11.9 \%) \\
\end{array}$ & & $\begin{array}{c}-1,622,580 \\
(23.8 \%) \\
\end{array}$ \\
\hline Utilities & $\begin{array}{c}-52,850 \\
(4.2 \%) \\
\end{array}$ & $\begin{array}{c}-32,128 \\
(3.9 \%) \\
\end{array}$ & $\begin{array}{l}-66,685 \\
(3.6 \%) \\
\end{array}$ & $\begin{array}{c}-64,471 \\
(3.0 \%) \\
\end{array}$ & $\begin{array}{l}-30,795 \\
(4.7 \%) \\
\end{array}$ & $\begin{array}{l}-530 \\
(1.3 \%) \\
\end{array}$ & $\begin{array}{c}-247,459 \\
(3.6 \%) \\
\end{array}$ \\
\hline Construction & & & & $\begin{array}{c}-63,292 \\
(2.9 \%) \\
\end{array}$ & & & $\begin{array}{c}-63,292 \\
(0.9 \%) \\
\end{array}$ \\
\hline $\begin{array}{l}\text { Transport and } \\
\text { logistics }\end{array}$ & $\begin{array}{c}-296,847 \\
(23.5 \%)\end{array}$ & $\begin{array}{l}-6,608 \\
(0.8 \%)\end{array}$ & $\begin{array}{c}-27,239 \\
(1.5 \%)\end{array}$ & $\begin{array}{c}-161,892 \\
(7.5 \%)\end{array}$ & $\begin{array}{c}-15,832 \\
(2.4 \%)\end{array}$ & $\begin{array}{c}-982 \\
(2.4 \%)\end{array}$ & $\begin{array}{c}-509,400 \\
(7.5 \%)\end{array}$ \\
\hline $\begin{array}{l}\text { Retail and personal } \\
\text { services }\end{array}$ & $\begin{array}{l}-4,827 \\
(0.4 \%) \\
\end{array}$ & & & & & & $\begin{array}{l}-4,827 \\
(0.1 \%) \\
\end{array}$ \\
\hline $\begin{array}{l}\text { Knowledge Intensive } \\
\text { Business Services }\end{array}$ & $\begin{array}{c}-36,978 \\
(2.9 \%) \\
\end{array}$ & & $\begin{array}{l}-9,123 \\
(0.5 \%)\end{array}$ & $\begin{array}{c}-22,305 \\
(1.0 \%) \\
\end{array}$ & $\begin{array}{l}-9,552 \\
(1.5 \%)\end{array}$ & $\begin{array}{l}-3,285 \\
(8.1 \%)\end{array}$ & $\begin{array}{c}-81,243 \\
(1.2 \%) \\
\end{array}$ \\
\hline Public services & $\begin{array}{c}-133,924 \\
(10.6 \%) \\
\end{array}$ & $\begin{array}{l}-84,856 \\
(10.2 \%) \\
\end{array}$ & $\begin{array}{c}-114,320 \\
(6.2 \%) \\
\end{array}$ & $\begin{array}{c}-32,893 \\
(1.5 \%) \\
\end{array}$ & $\begin{array}{c}-49,334 \\
(7.5 \%) \\
\end{array}$ & & $\begin{array}{c}-415,327 \\
(6.1 \%) \\
\end{array}$ \\
\hline \multicolumn{8}{|l|}{ Performance types } \\
\hline $\begin{array}{l}\text { GVA below average, } \\
\text { Prod below average. }\end{array}$ & $\begin{array}{c}-212,177 \\
(16.8 \%) \\
\end{array}$ & $\begin{array}{c}-102,143 \\
(12.3 \%) \\
\end{array}$ & $\begin{array}{c}-137,965 \\
(7.5 \%) \\
\end{array}$ & $\begin{array}{c}-164,340 \\
(7.6 \%)\end{array}$ & $\begin{array}{l}-65,962 \\
(10.1 \%) \\
\end{array}$ & & $\begin{array}{c}-682,587 \\
(10.0 \%)\end{array}$ \\
\hline $\begin{array}{l}\text { GVA below average, } \\
\text { Prod above average }\end{array}$ & $\begin{array}{c}-783,682 \\
(62.2 \%)\end{array}$ & $\begin{array}{c}-685,773 \\
(82.6 \%)\end{array}$ & $\begin{array}{c}-1,557,262 \\
(84.2 \%)\end{array}$ & $\begin{array}{c}-1,865,149 \\
(85.9 \%)\end{array}$ & $\begin{array}{c}-547,333 \\
(83.6 \%)\end{array}$ & $\begin{array}{l}-33,855 \\
(83.4 \%) \\
\end{array}$ & $\begin{array}{c}-5,473,054 \\
(80.4 \%)\end{array}$ \\
\hline $\begin{array}{l}\text { GVA above average, } \\
\text { Prod below average }\end{array}$ & $\begin{array}{c}-948 \\
(0.1 \%) \\
\end{array}$ & & $\begin{array}{c}-378 \\
(0.0 \%)\end{array}$ & & & & $\begin{array}{l}-1,326 \\
(0.0 \%) \\
\end{array}$ \\
\hline $\begin{array}{l}\text { GVA above average, } \\
\text { Prod above average }\end{array}$ & $\begin{array}{c}-264,092 \\
(20.9 \%)\end{array}$ & $\begin{array}{c}-42,169 \\
(5.1 \%) \\
\end{array}$ & $\begin{array}{c}-154,092 \\
(8.3 \%) \\
\end{array}$ & $\begin{array}{c}-141,050 \\
(6.5 \%)\end{array}$ & $\begin{array}{c}-41,603 \\
(6.4 \%) \\
\end{array}$ & $\begin{array}{c}-6,761 \\
(16.6 \%) \\
\end{array}$ & $\begin{array}{c}-649,767 \\
(9.5 \%) \\
\end{array}$ \\
\hline $\begin{array}{l}\text { Total negative } \\
\text { employment change }\end{array}$ & $\begin{array}{c}-1,260,899 \\
(100.0 \%)\end{array}$ & $\begin{array}{l}-830,085 \\
(100.0 \%)\end{array}$ & $\begin{array}{c}-1,849,697 \\
(100.0 \%)\end{array}$ & $\begin{array}{c}-2,170,539 \\
(100.0 \%)\end{array}$ & $\begin{array}{l}-654,898 \\
(100.0 \%)\end{array}$ & $\begin{array}{c}-40,616 \\
(100.0 \%)\end{array}$ & $\begin{array}{c}-6,806,734 \\
(100.0 \%)\end{array}$ \\
\hline Employment in 1971 & $4,536,668$ & $3,892,775$ & $6,660,088$ & $6,653,791$ & $3,746,650$ & 156,233 & $25,646,205$ \\
\hline $\begin{array}{l}\text { Negative empl.- } \\
\text { change as \% of } \\
\text { employment in } 1971\end{array}$ & $-27.8 \%$ & $-21.3 \%$ & $-27.8 \%$ & $-32.6 \%$ & $-17.5 \%$ & $-26.0 \%$ & $-26.5 \%$ \\
\hline
\end{tabular}


Table 8: Breakdown of positive employment change, by broad sector groups and performance types for groups of cities; 1971-2014

\begin{tabular}{|c|c|c|c|c|c|c|c|}
\hline & London & $\begin{array}{l}\text { Group I: } \\
\text { 'Pulling } \\
\text { Ahead' }\end{array}$ & $\begin{array}{c}\text { Group II: } \\
\text { 'Keeping } \\
\text { Pace' }\end{array}$ & $\begin{array}{l}\text { Group III: } \\
\text { 'Falling } \\
\text { Behind' }\end{array}$ & $\begin{array}{c}\text { Non-urban } \\
\text { TTWAs }\end{array}$ & Aberdeen & $\begin{array}{c}\text { Great } \\
\text { Britain }\end{array}$ \\
\hline \multicolumn{8}{|l|}{ Broad sector groups } \\
\hline $\begin{array}{l}\text { Agriculture and } \\
\text { fishing }\end{array}$ & $\begin{array}{l}1,542 \\
(0.1 \%)\end{array}$ & $\begin{array}{l}2,225 \\
(0.1 \%)\end{array}$ & $\begin{array}{l}9,974 \\
(0.3 \%)\end{array}$ & $\begin{array}{l}3,533 \\
(0.2 \%)\end{array}$ & $\begin{array}{l}26,307 \\
(1.1 \%) \\
\end{array}$ & & $\begin{array}{l}43,581 \\
(0.3 \%) \\
\end{array}$ \\
\hline $\begin{array}{l}\text { Coal and Other } \\
\text { mining }\end{array}$ & & & & & & $\begin{array}{c}243 \\
(0.1 \%)\end{array}$ & $\begin{array}{c}243 \\
(0.0 \%)\end{array}$ \\
\hline $\begin{array}{l}\text { Oil, Gas and Mining } \\
\text { support }\end{array}$ & & $\begin{array}{l}1,412 \\
(0.0 \%) \\
\end{array}$ & & & & $\begin{array}{c}30,822 \\
(18.2 \%) \\
\end{array}$ & $\begin{array}{l}32,234 \\
(0.2 \%) \\
\end{array}$ \\
\hline Metals and related & & & $\begin{array}{l}1,874 \\
(0.1 \%) \\
\end{array}$ & $\begin{array}{c}646 \\
(0.0 \%) \\
\end{array}$ & $\begin{array}{l}1,988 \\
(0.1 \%) \\
\end{array}$ & \begin{tabular}{|l}
2,348 \\
$(1.4 \%)$ \\
\end{tabular} & $\begin{array}{l}6,856 \\
(0.1 \%) \\
\end{array}$ \\
\hline \multicolumn{8}{|l|}{ Textiles and related } \\
\hline Light manufacturing & $\begin{array}{c}840 \\
(1.0 \%)\end{array}$ & & & & & $\begin{array}{l}1,745 \\
(1.0 \%)\end{array}$ & $\begin{array}{l}2,585 \\
(0.0 \%)\end{array}$ \\
\hline $\begin{array}{l}\text { High tech } \\
\text { manufacturing }\end{array}$ & & & & & $\begin{array}{c}596 \\
(0.0 \%) \\
\end{array}$ & \begin{tabular}{|l}
3,493 \\
$(2.1 \%)$ \\
\end{tabular} & $\begin{array}{l}4,089 \\
(0.0 \%) \\
\end{array}$ \\
\hline Utilities & $\begin{array}{l}14,993 \\
(0.7 \%) \\
\end{array}$ & $\begin{array}{l}25,952 \\
(0.8 \%) \\
\end{array}$ & $\begin{array}{l}29,582 \\
(0.8 \%) \\
\end{array}$ & $\begin{array}{l}26,763 \\
(1.2 \%) \\
\end{array}$ & $\begin{array}{l}21,819 \\
(0.9 \%) \\
\end{array}$ & $\begin{array}{c}599 \\
(0.4 \%) \\
\end{array}$ & $\begin{array}{c}119,708 \\
(0.9 \%) \\
\end{array}$ \\
\hline Construction & $\begin{array}{l}4,014 \\
(0.2 \%)\end{array}$ & $\begin{array}{c}132,563 \\
(3.9 \%)\end{array}$ & $\begin{array}{c}109,510 \\
(3.1 \%)\end{array}$ & & $\begin{array}{c}100,235 \\
(4.2 \%)\end{array}$ & $\begin{array}{c}3,129 \\
(1.9 \%)\end{array}$ & $\begin{array}{c}349,451 \\
(2.6 \%)\end{array}$ \\
\hline $\begin{array}{l}\text { Transport and } \\
\text { logistics }\end{array}$ & $\begin{array}{l}9,459 \\
(0.5 \%)\end{array}$ & $\begin{array}{c}269,001 \\
(8.0 \%)\end{array}$ & $\begin{array}{c}163,857 \\
(4.6 \%)\end{array}$ & $\begin{array}{l}56,397 \\
(2.6 \%)\end{array}$ & $\begin{array}{c}120,105 \\
(5.1 \%)\end{array}$ & $\begin{array}{c}7,807 \\
(4.6 \%)\end{array}$ & $\begin{array}{c}626,626 \\
(4.6 \%)\end{array}$ \\
\hline $\begin{array}{l}\text { Retail and personal } \\
\text { services }\end{array}$ & $\begin{array}{l}463,845 \\
(22.4 \%)\end{array}$ & $\begin{array}{l}907,323 \\
(27.0 \%)\end{array}$ & $\begin{array}{l}905,220 \\
(25.5 \%)\end{array}$ & $\begin{array}{l}517,827 \\
(24.1 \%)\end{array}$ & $\begin{array}{l}691,876 \\
(29.3 \%)\end{array}$ & $\begin{array}{l}37,324 \\
(22.1 \%)\end{array}$ & $\begin{array}{c}3,523,415 \\
(25.8 \%)\end{array}$ \\
\hline $\begin{array}{l}\text { Knowledge Intensive } \\
\text { Business Services }\end{array}$ & $\begin{array}{c}1,175,802 \\
(56.7 \%)\end{array}$ & $\begin{array}{c}1,192,231 \\
(35.4 \%)\end{array}$ & $\begin{array}{c}1,257,638 \\
(35.5 \%)\end{array}$ & $\begin{array}{l}660,621 \\
(30.7 \%)\end{array}$ & $\begin{array}{l}589,942 \\
(25.0 \%)\end{array}$ & $\begin{array}{l}50,374 \\
(29.8 \%)\end{array}$ & $\begin{array}{c}4,926,608 \\
(36.0 \%)\end{array}$ \\
\hline Public services & $\begin{array}{l}402,386 \\
(19.4 \%)\end{array}$ & $\begin{array}{l}835,846 \\
(24.8 \%)\end{array}$ & $\begin{array}{c}1,068,706 \\
(30.1 \%)\end{array}$ & $\begin{array}{l}884,087 \\
(41.1 \%)\end{array}$ & $\begin{array}{l}809,794 \\
(34.3 \%)\end{array}$ & $\begin{array}{c}31,070 \\
(18.4 \%)\end{array}$ & $\begin{array}{c}4,031,889 \\
(29.5 \%)\end{array}$ \\
\hline \multicolumn{8}{|l|}{ Performance types } \\
\hline $\begin{array}{l}\text { GVA below average, } \\
\text { Prod below average. }\end{array}$ & $\begin{array}{l}368,785 \\
(17.8 \%)\end{array}$ & $\begin{array}{l}860,358 \\
(25.6 \%)\end{array}$ & $\begin{array}{l}821,478 \\
(23.2 \%)\end{array}$ & $\begin{array}{l}432,754 \\
(20.1 \%)\end{array}$ & $\begin{array}{l}640,595 \\
(27.1 \%)\end{array}$ & $\begin{array}{c}27,844 \\
(16.5 \%)\end{array}$ & $\begin{array}{c}3,151,814 \\
(23.1 \%)\end{array}$ \\
\hline $\begin{array}{l}\text { GVA below average, } \\
\text { Prod above average }\end{array}$ & $\begin{array}{l}1,108 \\
(0.1 \%)\end{array}$ & $\begin{array}{c}7,800 \\
(0.2 \%)\end{array}$ & & & $\begin{array}{l}15,749 \\
(0.7 \%)\end{array}$ & $\begin{array}{c}7,576 \\
(4.5 \%)\end{array}$ & $\begin{array}{l}32,233 \\
(0.2 \%)\end{array}$ \\
\hline $\begin{array}{l}\text { GVA above average, } \\
\text { Prod below average }\end{array}$ & $\begin{array}{c}1,280,866 \\
(61.8 \%)\end{array}$ & $\begin{array}{c}1,734,371 \\
(51.5 \%)\end{array}$ & $\begin{array}{c}2,147,743 \\
(60.6 \%)\end{array}$ & $\begin{array}{c}1,480,757 \\
(68.9 \%)\end{array}$ & $\begin{array}{c}1,300,643 \\
(55.0 \%)\end{array}$ & $\begin{array}{l}67,960 \\
(40.2 \%) \\
\end{array}$ & $\begin{array}{c}8,012,340 \\
(58.6 \%)\end{array}$ \\
\hline $\begin{array}{l}\text { GVA above average, } \\
\text { Prod above average }\end{array}$ & $\begin{array}{l}422,122 \\
(20.4 \%)\end{array}$ & $\begin{array}{l}764,024 \\
(22.7 \%)\end{array}$ & $\begin{array}{l}577,140 \\
(16.3 \%)\end{array}$ & $\begin{array}{l}236,363 \\
(11.0 \%)\end{array}$ & $\begin{array}{l}405,675 \\
(17.2 \%)\end{array}$ & $\begin{array}{l}65,574 \\
(38.8 \%)\end{array}$ & $\begin{array}{c}2,470,898 \\
(18.1 \%)\end{array}$ \\
\hline $\begin{array}{l}\text { Total positive } \\
\text { employment change }\end{array}$ & $\begin{array}{c}2,072,881 \\
(100.0 \%)\end{array}$ & $\begin{array}{c}3,366,553 \\
(100.0 \%)\end{array}$ & $\begin{array}{c}3,546,361 \\
(100.0 \%)\end{array}$ & $\begin{array}{c}2,149,874 \\
(100.0 \%)\end{array}$ & $\begin{array}{c}2,362,662 \\
(100.0 \%)\end{array}$ & $\begin{array}{l}168,954 \\
(100.0 \%)\end{array}$ & $\begin{array}{c}13,667,285 \\
(100.0 \%)\end{array}$ \\
\hline Employment in 1971 & $4,536,668$ & $3,892,775$ & $6,660,088$ & $6,653,791$ & $3,746,650$ & 156,233 & $25,646,205$ \\
\hline $\begin{array}{l}\text { Positive empl.- } \\
\text { change as \% of } \\
\text { employment in } 1971\end{array}$ & $45.7 \%$ & $86.5 \%$ & $53.2 \%$ & $32.3 \%$ & $63.1 \%$ & $108.1 \%$ & $53.3 \%$ \\
\hline
\end{tabular}

\section{Conclusions}

Structural change is an ongoing process in dynamic economies. What the foregoing analysis demonstrates is that the profound structural transformations in the British since the beginning of the 1970s have played out quite differently across the country's various cities, shaping to a significant extent their divergent growth trajectories. Moreover the relative 
importance of structural change compared to other determinants of growth has varied across different types of city.

The cities in Group I (mainly cities in the South of England) - and London - have benefitted substantially from structural transformation, and have seen strong growth on the back of high-growth sectors, especially KIBS. In contrast, the cities in Group III (mainly cities in the North of England, Wales and Scotland) have seen decline or little growth in the traditional mainstays of their economy (mainly in manufacturing), and at the same time have been insufficiently able to grow and attract high-value private service activities. A third group of cities - Group II (those that have grown at more or less the national rate) - also have had to cope with the negative effects of structural change (though on average not quite to the same extent), but fared much better, and managed to make a relatively successful transition to a post-industrial economy, albeit with deep new patterns of inequality and labour market divisions. Non-urban TTWAs have on the whole had to face less of the negative impacts of change in the economic structure; moreover they actually seem to have profited to some extent from some manufacturing moving out of cities. Furthermore, the growth in private and public services in such areas has in general been on a par with the average for the nation. However, structural factors cannot in themselves account for the strong growth of cities in Group I, and many cities in Group II (and the non-urban TTWAs) also managed to deal with structural transformation better than Group III. Moreover, these factors are also insufficient to explain the very lacklustre performance of London until the turn of the century with a sudden turn-around in its fortunes thereafter, as well as the full extent of the lagging growth in Group III cities.

These results imply that the economic trajectories of cities are the complex and uneven outcomes of three fundamental sets of processes, all of which are interactive and potentially shaped by their policy and institutional contexts. These processes have often been distinguished in recent analyses of productivity growth. The first are those structural changes in output and employment shares which we have analysed here in depth. They centre on what we might term between-sector changes and refer to the rise of some industries and the decline of others. Our analysis has demonstrated the importance of these processes in some cities and has allowed us to understand the extent to which post-industrial transition produces growth-reducing structural change in some categories of city.

A second set of processes concerns within-sector changes and includes the way in which different parts of the same industry change and evolve over time. They highlight the way in which different firms within the same industry may have different productivity and innovation capabilities and track records. Cities host firms that are classified as belonging to the same industry but are actually quite different in their capabilities, employment, business models and strategies, and these 'within-sector' effects will also contribute to divergent economic performances. Our findings on the importance of 'local effects' in some types of cities may well indicate in part that these 'within-sector' effects also have a significant and growing 
spatial dimension. There are certainly many theoretical arguments which support and envisage this, as they suggest that globalisation and new supply chains and divisions of labour are widening differences between firms within industries and creating new types of specialisations in terms of functions, tasks and capabilities rather than entire sectors (Massey 1995; Baldwin, 2016). Different rates of entrepreneurship and firm demographics, as well as investment and foreign ownership, may also be reinforcing these spatial variations. We have not been able to investigate these within sector effects in this paper but this is certainly an important area for future research (See Martin et al (2017) Forthcoming.

However, a third set of processes centring on the development of cities' local supply factors are also interacting through time with both of these two types of industrial change. We know that there are important differences in the capabilities of cities to offer firms an attractive business environment through the supply of both appropriate 'hard and soft' infrastructure and the development of a local labour force sought by knowledge intensive and tradable industries. As we have argued elsewhere (Martin, et al 2016a) local areas start with an inherited pattern of land use and a resource base and institutions that were tailored to another era and the legacy of the past weighs heavily on their ability to adjust to new economic futures. Thus, the Group III cities tend to be amongst the oldest industrial cities with infrastructure, labour forces and a constrained land use pattern to match (See Fothergill and Gudgin, 1982). In constraint our fast growing Group I cities contain post second world war New Towns characterised by plentiful and planned land assembly, up to-date infrastructure and labour with skills more appropriate to the new age. While there is considerable scope for policy initiatives to modify and improve these local supply factors and characteristics, it is also the case that their development is primarily the outcome of a longterm cumulative and path dependent process in which industrial change plays a key role and accumulates different types of asset and institution (Storper, 2015).

In the course of the dynamic specialisation seen in city economies, the relationships between these three sets of processes are deeply recursive through time. Moreover, while beyond the scope of this paper, in order to properly understand the direction and degree of 'within and between sector' effects in a particular urban area we need to understand how city economies sit within regional ensemble of industries as well as within national and global markets and supply chain relationships (McCann, 2016) and distance from major markets like London.

What this suggests is that unambiguously determining the effects of consequences of structural change for urban economic performance is much more complex and difficult than might be assumed. While our dynamic shift-share analysis has allowed us to rigorously distinguish and pull out the direct effects of structural change on variations in city growth, it is not intended to identify more indirect and evolutionary path dependent effects that stem from structural change. But these indirect effects may be important and may be closely integrated with both within-sector and local supply-side development in specific ensembles. More specifically, studies of deindustrialisation in particular cities have increasingly 
emphasised that it is a long-term process which has lasting damaging and continuing effects on communities and economies (Martin and Gardiner, forthcoming). Indeed sociologists have described 'the half-life of deindustrialisation' to capture these lasting inhibiting influences effects on cultures and individuals (see Linkon, 2013; Strangleman, 2016).

In economic terms our evidence suggests that such effects have been particularly strong in Group III cities and it may be significant that cities in this group appear to have a stronger concentration of metals and related industries. Further investigation might find that the lasting effects of deindustrialisation may be strongest in such cities, where industrial plant and premises are hardest to convert, where land is often contaminated and where negative images of industrial decline are most often entrenched. Interestingly, Group II cities seem to have had greater concentrations in textiles which may have experienced less severe obstacles to conversion and renewal. But without further research we can at this stage only speculate about the causes of the differences between the two Groups of cities in responding to negative structural change. It may be that varied legacies of decline have shaped withinsector effects in service industries. It could also be that the two groups are distinguished more by their policy environments and character of their collective and institutional agency. Nevertheless, the broader point is that structural change and deindustrialisation are a key source of lasting path dependent effects in some cities (Martin and Sunley, 2006).

While it is important not to paint too deterministic and bleak a picture, as deindustrialised economies undoubtedly contain many resources and assets for renewal, our interpretation is that the legacies of these economies have frequently constrained and filtered the development of growth of service sector firms, as well as the provision of a skilled and educated labour force that is well-suited to knowledge-intensive firm growth. There may well be a type of spatial differentiation and sorting in which the emergence and growth of knowledge-intensive and high-productivity firms is shaped by the degree to which path dependence allows some cities to be more valued by these firms and their employees. Our decomposition techniques are not suited to fully capturing these long-term legacies and indirect effects as they will show up only as local competitiveness effects and residuals. They require much fuller and more detailed intensive investigation than we have been able to offer in this extensive and synthetic paper. Nevertheless, we hope to have highlighted their potential importance in conjunction with measurable structural industrial change.

\section{References}

Bailey, D. and Berkeley, N. (2014). Regional Responses to Recession: The Role of the West Midlands Regional Task Force, Regional Studies, 48, pp. 1797-1812.

Baldwin, R. (2016). The Great Convergence: Information Technology and the New Globalization. Cambridge MA: Belknap Press of Harvard University Press. 
Baranzi, M. and Scazzieri, R. (Eds) (1990). The Economic Theory of Structure and Change, Cambridge: Cambridge University Press.

Barff, R.A. and Knight, P. L. (1998). Dynamic Shift Share Analysis, Growth and Change, 19, pp. 1-10.

Berger, T. and Frey, C. B. (2016). Structural Transformation in the OECD: Digitalisation, Deindustrialisation and the Future of Work. OECD Social, Employment and Migration Working Papers No. 193. Paris: OECD Publishing.

Birch, K., MacKinnon, D. and Cumbers, A. (2010). 'Old Industrial Regions in Europe: A Comparative Assessment of Economic Performance', Regional Studies, 44, (1), pp. 35-53.

Blanchard, O and Katz, L (1992). Regional Evolutions, Brookings Papers on Economic Affairs, 1, pp. 1-61.

Boschma, R. and Martin, R.L. (Eds) (2010). Handbook of Evolutionary Economic Geography, Cheltenham: Edward Elgar

Bluestone, B. and Harrison, B. (1982). The Deindustrialization of America: Plant Closings, Community Abandonment, and the Dismantling of Basic Industry. New York NY: Basic Books.

Brunow, S and Blien, U. (2013). Agglomeration Effects on Labour Productivity: An Assessment with Microdata. Norface Migration. Discussion Paper No 2014.

Chern T.S., Ping, T.S., Robinson, E. and Wilson, P. (2002). Assessing Singapore's Export Competitiveness: A Dynamic Shift-Share Analysis, Occasional Paper 23, Economic Policy Department, Monetary Authority of Singapore.

Cheshire, P. Nathan, M. and Overman, H. (2014). Urban Economics and Urban Policy, Cheltenham: Edward Elgar.

Cornwall, J. and Cornwall, W. (1994). Growth Theory and Economic Structure, Economica, NS 61,242 , pp. 237-251.

Cowell, M. M. (2015). Dealing with Deindustrialization: Adaptive Resilience in American Midwestern Regions. London: Routledge.

Fenton, A, Tyler, P. Markkenen, S and Clarke, A. (2008). The "Ward Penalty in Birmingham". Barrow Cadbury Trust, 2008.

Fothergill, S. and Gudgin, G. (1982). Unequal Growth: Urban and Regional Employment in the United Kingdom, London: Heinemann.

Freeman, C. and Louca, F. (2001). As Time Goes By: From the Industrial Revolutions to the Information Revolution, New York: Oxford University Press. 
Frenken, K. and Boschma, R. (2007). 'A Theoretical Framework for Evolutionary Economic Geography: Industrial Dynamics and Urban Growth as a Branching Process', Journal of Economic Geography, 7, (5), pp. 635-649.

Fujita, M. and Thisse, J.F. (2002). Economics of Agglomeration: Cities, Industrial Location and Regional Growth.

Glaeser, E. and Gottlieb, J. (2008). The Economics of Place-Making Policies. IDEAS/RePEc 39. Issue 1 (Spring), pg 155-253.

Hausner, V. (Ed). (1987). Critical Issues in Urban Economic Development, Oxford: Clarenden Press.

Henderson, V. (2003). The Urbanization Process and Economic Growth: The So-what Question, Journal of Economic Growth, 8, pp. 47-71.

Hobor, G. (2013). 'Surviving the Era of Deindustrialization: The New Economic Geography of the Urban Rust Belt', Journal of Urban Affairs 35, (4), pp. 417-434.

Hudson, R. (2011). 'Geographies of Economic Decline', in Leyshon, A., Lee, R., McDowell, L. and Sunley, P. (Eds.). The Sage Handbook of Economic Geography. London: Sage, pp. 261-272.

Kaldor, N. (1966). Causes of the Slow Rate of Economic Growth in the United Kingdom Cambridge: Cambridge University Press.

Kaldor, N. (1967). Strategic factors in economic development, Ithaca, NY: Cornell University Press.

Kaldor, N. (1968). Productivity and Growth in Manufacturing Industry: A reply, Economica, 35, pp. 385-391.

Keeble, D and Tyler, P (1995). Enterprising Behaviour and the Urban-Rural Shift. Urban Studies. Vol 32. Issue 6.

Krüger, J. J. (2008). Productivity and Structural Change: A Review of the Literature, Journal of Economic Surveys, 22, pp. 330-363.

Kuznets, S. (1957). Quantitative Aspects of the Economic Growth of Nations: II. Industrial Distribution of National Product and Labour Force, Economic Development and Cultural Change, 5 (Supplement), pp. 3-111.

Kuznets, S. (1973). Modern Economic Growth: Findings and Reflections, American Economic Review, 63, pp.47-258.

Linkon, S. (2013). 'Narrating Past and Future: Deindustrialized Landscapes as Resources', International Labour and Working Class History, 84, (Fall), pp. 38-54. 
Lewis, J. and Townsend, A. R. (eds.) (1989) The North-South Divide: Regional Change in Britain in the 1980s. London: Paul Chapman Publishing.

LSE Growth Commission (2017). UK Growth: A New Chapter. London: London School of Economics.

Martin, R. (1986) 'Thatcherism and Britain's Industrial Landscape', in Martin, R. and Rowthorn, B. (eds.). The Geography of De-industrialisation. Basingstoke: Macmillan, pp. 238-290.

Martin, R. and Rowthorn, B. (1998). (eds.). The Geography of De-industrialisation. Basingstoke: Macmillan, pp. 1-30.

Martin, R. and Sunley, P. (2006). 'Path Dependence and Regional Economic Evolution', Journal of Economic Geography, 6, (4), pp. 395-437.

Martin, R.L., Tyler, P. and Gardiner, B. (2015). The Evolving Economic Performance of British Cities: City Growth Patterns, 1981-2011, Working Paper 5, Foresight Programme of The Future of Cities, UK Government Office for Science, Department of Business, Innovation and Skills, London.

Martin, R.L. and Sunley, P. (2015). On the Concept of Regional Economic Resilience: Conceptualisation and Explanation, Journal of Economic Geography, 15, pp. 1-42.

Martin, R., Sunley, P., Tyler, P. and Gardiner, B. (2016a). 'Divergent Cities in Post-industrial Britain', Cambridge Journal of Regions, Economy and Society, 9, (2), pp. 269-299.

Martin, R., Pike, A., Tyler, P. and Gardiner, B. (2016b). 'Spatially Rebalancing the UK Economy: Towards and New Policy Model?' Regional Studies, 50, (2), pp. 342-357.

Martin, R. and Gardiner, B. (2017). 'Reviving the 'Northern Powerhouse' and Spatially Rebalancing the British Economy: The Scale of the Challenge', in Berry, C. and Giovannini, A. (Eds.) The Political Economy of the Northern Powerhouse. Basingstoke: Palgrave.

Massey, D. (1995). Spatial Divisions of Labour: Social Structures and the Geography of Production, Second Edition. Basingstoke: Palgrave-Macmillan.

McCann, P. (2016). The UK Regional-National Economic Problem: Geography, Globalisation and Governance. London: Routledge.

Metcalfe, J.S. (2003). Industrial Growth and the Theory of Retardation: Precursors of an Adaptive Evolutionary Theory of Economic Change, Revue Économique, 54, pp. 407-432.

Metcalfe, J.S., Foster, J. and Ramlogan, R. (2006). Adaptive Economic Growth, Cambridge Journal of Economics, 30, pp. 7-32.

Moretti, E. (2013). The New Geography of Jobs. Boston MA: Mariner Books. 
Neffke, F., Henning, M. and Boschma, R. (2011). 'How do Regions Diversify over Time? Industry Relatedness and the Development of New Growth Paths in Regions', Economic Geography, 87, (3), pp. 237-265.

Pasinetti, L. (1981). Structural Change and Economic Growth, Cambridge: Cambridge University Press.

Pasinetti, L. (1993). Structural Economic Dynamics, Cambridge: Cambridge University Press.

Pike, A. (2009). 'De-Industrialization', in Kitchin, R. and Thrift, N. (eds.) International Encyclopaedia of Human Geography. Oxford: Elsevier, pp. 51-59.

Pike, A., Dawley, S. and Tomaney, J. (2010). Resilience, Adaptation and Adaptability, Cambridge Journal of Regions, Economy and Society, 3, pp. 59-70

Power, A., Plöger, J. and Winkler, A. (2010). Phoenix Cities: The Fall and Rise of Great Industrial Cities. Bristol: Policy Press.

Rhodes, J. (1986). 'Regional Dimensions of Industrial Decline', in Martin, R. and Rowthorn, B. (eds.) The Geography of De-industrialisation. Basingstoke: Macmillan, pp. 138-168.

Rhodes, C. (2016). Industrial Strategy, House of Commons Library Briefing Paper 07682, www.parliament.uk/commons-library | intranet.parliament.uk/commons-library | papers@parliament.uk | @commonslibrary

Rodrik, D. (2016) 'Innovation is Not Enough', Project Syndicate 9 June 2016. https://www.project-syndicate.org/commentary/innovation-impact-on-productivity-bydani-rodrik-2016-06

Roncolato, L. and Kucera, D. (2014). Structural Drivers of Productivity and Employment Growth: A Decomposition Analysis for 81 Countries, Cambridge Journal of Economics, 38, pp. 399-424.

Rowthorn, R. (1986). 'De-industrialisation in Britain', in Martin, R. and Rowthorn, B. (eds.) The Geography of De-industrialisation. Basingstoke: Macmillan, pp. 1-30.

Rowthorn, R. (2010). 'Combined and Uneven Development: Reflections on the North-South Divide', Spatial Economic Analysis, 5, (4), pp. 363-388.

Selting, A. and Loveridge, S. (1990). Testing dynamic shift-share, http://www.jrapjournal.org/pastvolumes/1990/v24/24-1-2.pdf.

Selting, A.C. and Loveridge, S. (1992). A Summary of the Literature on Shift-Share Analysis, Staff Paper P92-13, Department of Agricultural and Applied Economics, University of Minnesota. 
Storper, M. (2013). Keys to the City: How Economics, Institutions, Social Interaction, and Politics Shape Development. Oxford: Princeton University Press.

Storper, M., Kemeney, T., Makarem, N. P., and Osman, T. (2015). The Rise and Fall of Urban Economies: Lessons from San Francisco and Los Angeles. Stanford CA: Stanford University Press.

Strangleman, T. (2016). 'Deindustrialisation and the Historical Sociological Imagination: Making Sense of Work and Industrial Change', Sociology, (2016), pp. 1-17.

Thirlwall, A.P. (1983). "A Plain Man's Guide to Kaldor's Growth Laws," Journal of Post Keynesian Economics, M.E. Sharpe, Inc., vol. 5(3), pages 345-358, April.

Townsend, A. R. (1983). The Impact of Recession on Industry, Employment and the Regions, 1976-1981. London: Croom Helm.

\section{Annex 1. Data Construction}

\section{Definition}

The definition of cities used in the paper is based on the concept of the Travel To Work Area (TTWA) which is defined by the ONS ${ }^{5}$ as a self-contained labour market area where 'at least $75 \%$ of the area's resident workforce work in the area and at least $75 \%$ of the people who work in the area also live in the area. The area must also have an economically active population of at least 3,500.' The TTWAs are revised every 10 years in line with new information from the census on commuting patterns, with the most recent list dating from 2011 where 228 TTWAs were identified ${ }^{6}$.

\section{Developing a time series sectoral TTWA-city database}

While the functional definition of the TTWA is well-founded, a drawback to its use is that the data are typically only available for the year of definition, making analysis over time impossible. To circumvent this problem, Cambridge Econometrics (CE) made use of its own Local Authority District (LAD) database which is based on 45 sectors for GVA and employment, as well as total and working-age population, over the period 1981-2014, and matched this to the TTWA boundaries. In addition, it both extended the time period of the data back to 1971, and increased the sector definition for GVA and employment to 82 sectors. Table A1 below provides a description and definition of the 45 and 82 sector disaggregations and their SIC codes.

TableA 1: 45-sector and 82-sector disaggregation

https://www.ons.gov.uk/employmentandlabourmarket/peopleinwork/employmentandemployeetypes/article s/traveltoworkareaanalysisingreatbritain/2016 for more information.

${ }^{6}$ See http://ons.maps.arcgis.com/apps/MapSeries/index.html?appid=397ccae5d5c7472e 87cf0ca766386cc2 for an interactive map of the TTWA boundaries. 


\begin{tabular}{|c|c|c|}
\hline 45 Sectors & 82 Sectors & $\begin{array}{l}\text { SIC } 2007 \text { codes } \\
\text { (82 Sector) }\end{array}$ \\
\hline \multirow[t]{3}{*}{ Agriculture, forestry \& fishing } & $\begin{array}{l}\text { Crop and animal production, hunting and } \\
\text { related service activities }\end{array}$ & 1 \\
\hline & Forestry and logging & 2 \\
\hline & Fishing and aquaculture & 3 \\
\hline \multirow[t]{5}{*}{ Mining \& quarrying } & Mining of coal and lignite & 5 \\
\hline & Extraction of crude petroleum and natural gas & 6 \\
\hline & Mining of metal ores & 7 \\
\hline & Other mining and quarrying & 8 \\
\hline & Mining support service activities & 9 \\
\hline \multirow[t]{3}{*}{ Food, drink \& tobacco } & Manufacture of food products & 10 \\
\hline & Manufacture of beverages & 11 \\
\hline & Manufacture of tobacco products & 12 \\
\hline \multirow[t]{3}{*}{ Textiles etc } & Manufacture of textiles & 13 \\
\hline & Manufacture of wearing apparel & 14 \\
\hline & Manufacture of leather and related products & 15 \\
\hline \multirow[t]{2}{*}{ Wood \& paper } & $\begin{array}{l}\text { Manufacture of wood and of products of wood } \\
\text { and cork, except furniture; manufacture of } \\
\text { articles of straw and plaiting materials }\end{array}$ & 16 \\
\hline & Manufacture of paper and paper products & 17 \\
\hline Printing \& recording & Printing and reproduction of recorded media & 18 \\
\hline Coke \& petroleum & $\begin{array}{l}\text { Manufacture of coke and refined petroleum } \\
\text { products }\end{array}$ & 19 \\
\hline Chemicals & $\begin{array}{l}\text { Manufacture of chemicals and chemical } \\
\text { products }\end{array}$ & 20 \\
\hline Pharmaceuticals & $\begin{array}{l}\text { Manufacture of basic pharmaceutical products } \\
\text { and pharmaceutical preparations }\end{array}$ & 21 \\
\hline \multirow[t]{2}{*}{ Non-metallic mineral products } & Manufacture of rubber and plastic products & 22 \\
\hline & $\begin{array}{l}\text { Manufacture of other non-metallic mineral } \\
\text { products }\end{array}$ & 23 \\
\hline \multirow[t]{2}{*}{ Metals \& metal products } & Manufacture of basic metals & 24 \\
\hline & $\begin{array}{l}\text { Manufacture of fabricated metal products, } \\
\text { except machinery and equipment }\end{array}$ & 25 \\
\hline Electronics & $\begin{array}{l}\text { Manufacture of computer, electronic and } \\
\text { optical products }\end{array}$ & 26 \\
\hline Electrical equipment & Manufacture of electrical equipment & 27 \\
\hline Machinery & $\begin{array}{l}\text { Manufacture of machinery and equipment } \\
\text { n.e.c. }\end{array}$ & 28 \\
\hline Motor vehicles & $\begin{array}{l}\text { Manufacture of motor vehicles, trailers and } \\
\text { semi-trailers }\end{array}$ & 29 \\
\hline Other transport equipment & Manufacture of other transport equipment & 30 \\
\hline \multirow[t]{2}{*}{ Other manufacturing \& repair } & Manufacture of furniture & 31 \\
\hline & $\begin{array}{l}\text { Other manufacturing; Repair and installation } \\
\text { of machinery and equipment }\end{array}$ & 32,33 \\
\hline Electricity \& gas & $\begin{array}{l}\text { Electricity, gas, steam and air conditioning } \\
\text { supply }\end{array}$ & 35 \\
\hline \multirow[t]{2}{*}{ Water, sewerage \& waste } & Water collection, treatment and supply & 36 \\
\hline & Sewerage & 37 \\
\hline
\end{tabular}




\begin{tabular}{|c|c|c|}
\hline 45 Sectors & 82 Sectors & $\begin{array}{l}\text { SIC } 2007 \text { codes } \\
\text { (82 Sector) }\end{array}$ \\
\hline & $\begin{array}{l}\text { Waste collection, treatment and disposal } \\
\text { activities; materials recovery }\end{array}$ & 38 \\
\hline & $\begin{array}{l}\text { Remediation activities and other waste } \\
\text { management services. This division includes } \\
\text { the provision of remediation services, i.e. the } \\
\text { cleanup of contaminated buildings and sites, } \\
\text { soil, surface or ground water. }\end{array}$ & 39 \\
\hline Construction & $\begin{array}{l}\text { Construction of buildings, Civil engineering, } \\
\text { Specialised construction activities }\end{array}$ & $41,42,43$ \\
\hline Motor vehicles trade & $\begin{array}{l}\text { Wholesale and retail trade and repair of motor } \\
\text { vehicles and motorcycles }\end{array}$ & 45 \\
\hline Wholesale trade & $\begin{array}{l}\text { Wholesale trade, except of motor vehicles and } \\
\text { motorcycles }\end{array}$ & 46 \\
\hline Retail trade & $\begin{array}{l}\text { Retail trade, except of motor vehicles and } \\
\text { motorcycles }\end{array}$ & 47 \\
\hline Land transport & Land transport and transport via pipelines & 49 \\
\hline Water transport & Water transport & 50 \\
\hline Air transport & Air transport & 51 \\
\hline Warehousing \& postal & $\begin{array}{l}\text { Warehousing and support activities for } \\
\text { transportation }\end{array}$ & 52 \\
\hline & Postal and courier activities & 53 \\
\hline Accommodation & Accommodation & 55 \\
\hline Food \& beverage services & Food and beverage service activities & 56 \\
\hline Media & Publishing activities & 58 \\
\hline & $\begin{array}{l}\text { Motion picture, video and television } \\
\text { programme production, sound recording and } \\
\text { music publishing activities }\end{array}$ & 59 \\
\hline & Programming and broadcasting activities & 60 \\
\hline & Telecommunications & 61 \\
\hline IT services & $\begin{array}{l}\text { Computer programming, consultancy and } \\
\text { related activities }\end{array}$ & 62 \\
\hline & Information service activities & 63 \\
\hline Financial \& insurance & $\begin{array}{l}\text { Financial service activities, except insurance } \\
\text { and pension funding }\end{array}$ & 64 \\
\hline & $\begin{array}{l}\text { Insurance, reinsurance and pension funding, } \\
\text { except compulsory social security }\end{array}$ & 65 \\
\hline & $\begin{array}{l}\text { Activities auxiliary to financial services and } \\
\text { insurance activities }\end{array}$ & 66 \\
\hline Real estate & Real estate activities & 68 \\
\hline Legal \& accounting & Legal and accounting activities & 69 \\
\hline $\begin{array}{l}\text { Head offices \& management } \\
\text { consultancies }\end{array}$ & $\begin{array}{l}\text { Activities of head offices; management } \\
\text { consultancy activities }\end{array}$ & 70 \\
\hline $\begin{array}{l}\text { Architectural \& engineering } \\
\text { services }\end{array}$ & $\begin{array}{l}\text { Architectural and engineering activities; } \\
\text { technical testing and analysis }\end{array}$ & 71 \\
\hline & Scientific research and development & 72 \\
\hline Other professional services & Advertising and market research & 73 \\
\hline & $\begin{array}{l}\text { Other professional, scientific and technical } \\
\text { activities }\end{array}$ & 74 \\
\hline
\end{tabular}




\begin{tabular}{|c|c|c|}
\hline 45 Sectors & 82 Sectors & $\begin{array}{l}\text { SIC } 2007 \text { codes } \\
\text { (82 Sector) }\end{array}$ \\
\hline & Veterinary activities & 75 \\
\hline \multirow[t]{6}{*}{ Business support services } & Rental and leasing activities & 77 \\
\hline & Employment activities & 78 \\
\hline & $\begin{array}{l}\text { Travel agency, tour operator and other } \\
\text { reservation service and related activities }\end{array}$ & 79 \\
\hline & Security and investigation activities & 80 \\
\hline & Services to buildings and landscape activities & 81 \\
\hline & $\begin{array}{l}\text { Office administrative, office support and other } \\
\text { business support activities }\end{array}$ & 82 \\
\hline $\begin{array}{ll}\text { Public } & \text { Administration } \quad \& \\
\text { Defence } & \end{array}$ & $\begin{array}{l}\text { Public administration and defence; } \\
\text { compulsory social security }\end{array}$ & 84 \\
\hline Education & Education & 85 \\
\hline Health & Human health activities & 86 \\
\hline \multirow[t]{2}{*}{ Residential \& social } & Residential care activities & 87 \\
\hline & Social work activities without accommodation & 88 \\
\hline Arts & Creative, arts and entertainment activities & 90 \\
\hline \multirow[t]{4}{*}{ Recreational services } & $\begin{array}{l}\text { Libraries, archives, museums and other } \\
\text { cultural activities }\end{array}$ & 91 \\
\hline & Gambling and betting activities & 92 \\
\hline & $\begin{array}{l}\text { Sports activities and amusement and } \\
\text { recreation activities }\end{array}$ & 93 \\
\hline & Activities of membership organisations & 94 \\
\hline \multirow[t]{2}{*}{ Other services } & $\begin{array}{l}\text { Repair of computers and personal and } \\
\text { household goods }\end{array}$ & 95 \\
\hline & Other personal service activities & 96 \\
\hline
\end{tabular}

An explanation is provided below of each of these stages involved.

(i) Cambridge Econometrics LAD database (1981-2014, 45 sectors)

CE maintains a disaggregated database of employment ${ }^{7}$ and (constant price) GVA data by industry (45 detailed sectors) from 1981 for all unitary authorities and local authority districts in Great Britain.

This database is formed from a UK-level 86-sector database, which is based on raw data from the ONS and CE's own estimates. Regional (NUTS1) data are constructed at the 45 sector level, which are scaled and made consistent with the UK sectoral data. These data (back to 1992 for employees and 1996 for self-employed) are based on the quarterly workforce jobs data from the ONS as the main dataset which provides data by 19 industries by region, type (full-time, part-time and self-employed) and gender. To move from the 19 industries to 45 sectors, data from the Business Registry and Employment Survey (BRES) and Annual Business Inquiry (ABI), based on SIC07, were used to generate industry shares by each region

The GVA data are consistent with sectoral data at NUTS 2 level from the ONS Regional Accounts.

(ii) Extending the time period back to 1971

\footnotetext{
${ }^{7}$ The measure of employment is workplace based jobs, which include full-time, part-time and self-employed.
} 
To extrapolate the dataset back to 1971, the growth rates of CE's existing historical dataset are used, which are themselves based on older ONS data from the Census of Employment and ABI. These older datasets were converted to the latest standard industrial classification (SICO7) to maintain consistency with the more recent data. Historical boundary changes for regions and local authorities were also adjusted for, as part of this process to ensure consistency.

(iii) Increasing disaggregation to 82 sectors

At local area level, employment data are the most readily available from the ONS (through NOMIS ${ }^{8}$ ), and these data were the first to be collected and processed. The latest available data (BRES data based on SIC 2007) were obtained, with older vintages of data (from $\mathrm{BRES}^{9}, \mathrm{ABI}$ and the Census of Employment ${ }^{10}$ ) being used to construct consistent historical growth rates which were then applied to the latest levels to give a consistent back series for each sector and local authority district. Table A2 below provides a summary of sources.

Table A2: Datasets used for detailed sector dissaggregation

\begin{tabular}{|l|l|l|}
\hline Dataset & Time period & Sectors \\
\hline BRES & $2009-2014$ & 86 (effectively 82*)11 \\
\hline BRES & $2008-2009$ & 86 (effectively 82*) \\
\hline Annual Business Inquiry - Employee Analysis & $1998-2008$ & 60 (split to 82) \\
\hline $\begin{array}{l}\text { Annual Business Employment -Survey Employee } \\
\text { Analysis }\end{array}$ & $1991-1998$ & 60 (split to 82) \\
\hline Census of employment - Employee Analysis & $1975-1981$ & 183 (aggregated to 82) \\
\hline Census of employment - Employee Analysis & $1971-1974$ & 183 (aggregated to 82) \\
\hline
\end{tabular}

The GVA data were then constructed by applying NUTS2-level productivity data (as provided by the ONS) to the employment data. This required the mapping of NUTS2 regions to districts and the mapping of the detailed sectors to the fewer sectors for which sub-national productivity data is available from the ONS.

Finally, LAD-level population data were collected from the ONS mid-year population estimates and presented alongside the employment and GVA data.

(iv) Fitting the LAD database to TTWA definitions

With the LAD database complete, the final process was to match the areas to the TTWA definitions. There was no easy way to do this - because both LADs and TTWAs are non-overlapping geographies all allocations were required to add up. The process was largely a trial and error one, matching the

\footnotetext{
${ }^{8}$ https://www.nomisweb.co.uk/

${ }^{9}$ BRES is an ONS business survey which (from 2010 onwards) replaced the Annual Business Inquiry (ABI).

${ }^{10}$ Also obtained from NOMIS.

${ }^{11}$ The 86 sectors mentioned in the table did not map well to the 45 sectors. As a result, the number of sectors were aggregated to map 82 sectors to the 45 .
} 
boundaries, looking at large urban agglomerations and judging the proportions of which LAD should go in which TTWA - some were easy, others less so. An error margin of $+/-5 \%$ was used to judge whether the combined proportions of LAD populations was sufficiently close to the TTWA population and density in 2011. As the focus of the work was on larger urban areas, the matching process was concentrated mostly on those areas that would subsequently be used for more detailed analysis - the logic behind this selection is described below.

\section{Choosing which cities to analyse}

The full set of 228 TTWAs was considered too many for city-based analysis, particularly as many of them are quite small and/or do not contain urban centres of any significance. Analysis took place to determine a suitable cut-off point based on population size and density of the TTWAs in 2014, and on this basis the top 85 TTWAs ${ }^{12}$ were selected. Combined, the selected TTWAs used in the paper account for $82 \%$ of GB population, $83 \%$ of employment and $86 \%$ of output in 2014 .

\section{Annex 2. Definition of City Groups and Sensitivity Analysis}

Table A3: Scenario 0: Groups of British cities defined according to half standard deviation around weighted national average $(0.00 \%)$ of cumulative differential performance over 1971-2014

\begin{tabular}{|l|l|l|}
\hline $\begin{array}{l}\text { Group I } \\
\text { (27 cities) }\end{array}$ & GVA + & $\begin{array}{l}\text { Milton Keynes, Northampton, Basingstoke, Swindon, Telford, } \\
\text { Leamington Spa, Crawley, Peterborough, Chichester, Tunbridge Wells, } \\
\text { Mansfield, Reading, Guildford, High Wycombe \& Aylesbury, Derby, } \\
\text { Crewe, Norwich, Chesterfield, Bournemouth, Exeter, Cambridge, } \\
\text { Slough \& Heathrow, Lincoln, York, Southampton, Eastbourne, Ipswich }\end{array}$ \\
\hline $\begin{array}{l}\text { Group II } \\
\text { (33 cities) }\end{array}$ & GVA 0 & $\begin{array}{l}\text { Trowbridge, Dunfermline \& Kirkcaldy, Wakefield, Shrewsbury, Halifax, } \\
\text { Blyth \& Ashington, Colchester, Kettering \& Wellingborough, Oxford, } \\
\text { Stevenage, Gloucester, Doncaster, Leeds, Bristol, Nottingham, } \\
\text { Chelmsford, Falkirk \& Stirling, Luton, Leicester, Worcester \& } \\
\text { Kidderminster, Chester, Southend, Sunderland, Barnsley, Warrington } \\
\text { \& Wigan, Huddersfield, Brighton, Edinburgh, Bedford, Preston, } \\
\text { Durham \& Bishop Auckland, Bradford, Manchester }\end{array}$ \\
\hline $\begin{array}{l}\text { Group III } \\
\text { (23 cities) }\end{array}$ & GVA - & $\begin{array}{l}\text { Portsmouth, Coventry, Cardiff, Hull, Newport, Medway, Merthyr } \\
\text { Tydfil, Motherwell \& Airdrie, Middlesbrough \& Stockton, Sheffield, } \\
\text { Blackburn, Plymouth, Newcastle, Birmingham, Dudley, Birkenhead, } \\
\text { Blackpool, Stoke-on-Trent, Dundee, Swansea, Glasgow, } \\
\text { Wolverhampton, Liverpool }\end{array}$ \\
\hline London & London \\
\hline Aberdeen & Aberdeen \\
\hline $\begin{array}{l}\text { Non-urban } \\
\text { TTWAs }\end{array}$ & \begin{tabular}{l} 
TTWAs which are not classified as cities \\
\hline
\end{tabular} & \\
\hline
\end{tabular}

\footnotetext{
12 TTWAs in Northern Ireland were not considered because the CE LAD database does not cover this region, and so the process of data extension and matching was not possible.
} 
Table A4: Scenario 1: Groups of British cities defined according to half standard deviation around national rate $(\mathbf{2 . 1 5 \% )}$ ) of compound growth rate over 1971-2014

\begin{tabular}{|l|l|l|}
\hline $\begin{array}{l}\text { Group I } \\
\text { (23 cities) }\end{array}$ & GVA + & $\begin{array}{l}\text { Milton Keynes, Northampton, Basingstoke, Swindon, Telford, } \\
\text { Leamington Spa, Crawley, Tunbridge Wells, Peterborough, Chichester, } \\
\text { Reading, Guildford, High Wycombe \& Aylesbury, Derby, Mansfield, } \\
\text { Crewe, Norwich, Bournemouth, Exeter, Slough \& Heathrow, } \\
\text { Cambridge, Lincoln, Southampton }\end{array}$ \\
\hline $\begin{array}{l}\text { Group II } \\
\text { (34 cities) }\end{array}$ & GVA 0 & $\begin{array}{l}\text { Ipswich, Eastbourne, Trowbridge, Chesterfield, York, Shrewsbury, } \\
\text { Halifax, Blyth \& Ashington, Colchester, Dunfermline \& Kirkcaldy, } \\
\text { Stevenage, Wakefield, Leeds, Gloucester, Oxford } \\
\text { Kettering \& Wellingborough, Bristol, Chelmsford, Nottingham, Luton, } \\
\text { Falkirk and Stirling, Leicester, Barnsley, Warrington \& Wigan, } \\
\text { Worcester \& Kidderminster, Southend, Chester, Doncaster, } \\
\text { Huddersfield, Sunderland, Brighton, Edinburgh, Bedford, Bradford }\end{array}$ \\
\hline $\begin{array}{l}\text { Group III } \\
\text { (26 cities) }\end{array}$ & GVA - & $\begin{array}{l}\text { Preston, Manchester, Durham \& Bishop Auckland, Cardiff, } \\
\text { Portsmouth, Coventry, Hull, Medway, Newport, Merthyr Tydfil, } \\
\text { Motherwell \& Airdrie, Plymouth, Sheffield, Newcastle, Blackburn, } \\
\text { Birmingham, Middlesbrough \& Stockton, Dudley, Birkenhead, } \\
\text { Blackpool, Stoke-on-Trent, Dundee, Swansea, Glasgow, } \\
\text { Wolverhampton, Liverpool }\end{array}$ \\
\hline London & & \begin{tabular}{l} 
London \\
\hline Aberdeen
\end{tabular} \\
\hline Non-urban \\
TTWAs
\end{tabular}

Table A5: Scenario 2: Groups of British cities defined according to full standard deviation around weighted national average $(0.00 \%)$ of cumulative differential performance over 1971-2014

\begin{tabular}{|l|l|l|}
\hline $\begin{array}{l}\text { Group I } \\
\text { (13 cities) }\end{array}$ & GVA + & $\begin{array}{l}\text { Milton Keynes, Northampton, Basingstoke, Swindon, Telford, } \\
\text { Leamington Spa, Crawley, Peterborough, Chichester, Tunbridge Wells, } \\
\text { Mansfield, Reading, Guildford }\end{array}$ \\
\hline $\begin{array}{l}\text { Group II } \\
\text { (62 cities) }\end{array}$ & GVA 0 & $\begin{array}{l}\text { High Wycombe \& Aylesbury, Derby, Crewe, Norwich, Chesterfield, } \\
\text { Bournemouth, Exeter, Cambridge, Slough \& Heathrow, Lincoln, York, } \\
\text { Southampton, Eastbourne, Ipswich, Trowbridge, Dunfermline \& } \\
\text { Kirkcaldy, Wakefield, Shrewsbury, Halifax, Blyth \& Ashington, } \\
\text { Colchester, Kettering \& Wellingborough, Oxford, Stevenage, } \\
\text { Gloucester, Doncaster, Leeds, Bristol, Nottingham, Chelmsford, Falkirk } \\
\text { \& Stirling, Luton, Leicester, Worcester \& Kidderminster, Chester, } \\
\text { Southend, Sunderland, Barnsley, Warrington \& Wigan, Huddersfield, } \\
\text { Brighton, Edinburgh, Bedford, Preston, Durham \& Bishop Auckland, } \\
\text { Bradford, Manchester, Portsmouth, Coventry, Cardiff, Hull, Newport, } \\
\text { Medway, Merthyr Tydfil, Motherwell \& Airdrie, Middlesbrough \& } \\
\text { Stockton, Sheffield, Blackburn, Plymouth, Newcastle, Birmingham, } \\
\text { Dudley }\end{array}$ \\
\hline $\begin{array}{l}\text { Group III } \\
\text { (8 cities) }\end{array}$ & GVA - & $\begin{array}{l}\text { Birkenhead, Blackpool, Stoke-on-Trent, Dundee, Swansea, Glasgow, } \\
\text { Wolverhampton, Liverpool }\end{array}$ \\
\hline London & & London \\
\hline Aberdeen & & Aberdeen \\
\hline Non-urban & & TTWAs which are not classified as cities \\
TTWAs & & \\
\hline
\end{tabular}


Table A6: Scenario 3A: Groups of British cities defined according to half standard deviation around weighted national average $(0.00 \%)$ of cumulative differential performance over 1971-2014, with smaller Group I (-5 cities) and larger Group III ( +5 cities)

\begin{tabular}{|l|l|l|}
\hline $\begin{array}{l}\text { Group I } \\
\text { (22 cities) }\end{array}$ & GVA + & $\begin{array}{l}\text { Milton Keynes, Northampton, Basingstoke, Swindon, Telford, } \\
\text { Leamington Spa, Crawley, Peterborough, Chichester, Tunbridge Wells, } \\
\text { Mansfield, Reading, Guildford, High Wycombe \& Aylesbury, Derby, } \\
\text { Crewe, Norwich, Chesterfield, Bournemouth, Exeter, Cambridge, } \\
\text { Slough \& Heathrow }\end{array}$ \\
\hline $\begin{array}{l}\text { Group II } \\
\text { (33 cities) }\end{array}$ & GVA 0 & $\begin{array}{l}\text { Lincoln, York, Southampton, Eastbourne, Ipswich, Trowbridge, } \\
\text { Dunfermline \& Kirkcaldy, Wakefield, Shrewsbury, Halifax, Blyth \& } \\
\text { Ashington, Colchester, Kettering \& Wellingborough, Oxford, } \\
\text { Stevenage, Gloucester, Doncaster, Leeds, Bristol, Nottingham, } \\
\text { Chelmsford, Falkirk \& Stirling, Luton, Leicester, Worcester \& } \\
\text { Kidderminster, Chester, Southend, Sunderland, Barnsley, Warrington } \\
\text { \& Wigan, Huddersfield, Brighton, Edinburgh }\end{array}$ \\
\hline $\begin{array}{l}\text { Group III } \\
\text { (28 cities) }\end{array}$ & GVA - & $\begin{array}{l}\text { Bedford, Preston, Durham \& Bishop Auckland, Bradford, Manchester, } \\
\text { Portsmouth, Coventry, Cardiff, Hull, Newport, Medway, Merthyr } \\
\text { Tydfil, Motherwell \& Airdrie, Middlesbrough \& Stockton, Sheffield, } \\
\text { Blackburn, Plymouth, Newcastle, Birmingham, Dudley, Birkenhead, } \\
\text { Blackpool, Stoke-on-Trent, Dundee, Swansea, Glasgow, } \\
\text { Wolverhampton, Liverpool }\end{array}$ \\
\hline London & London \\
\hline Aberdeen & & Aberdeen \\
\hline Non-urban \\
TTWAs
\end{tabular}


Table A7: Scenario 3B: Groups of British cities defined according to half standard deviation around weighted national average $(0.00 \%)$ of cumulative differential performance over 1971-2014, with larger Group I (+5 cities) and smaller Group III (-5 cities).

\begin{tabular}{|l|l|l|}
\hline $\begin{array}{l}\text { Group I } \\
\text { (32 cities) }\end{array}$ & GVA + & $\begin{array}{l}\text { Milton Keynes, Northampton, Basingstoke, Swindon, Telford, } \\
\text { Leamington Spa, Crawley, Peterborough, Chichester, Tunbridge Wells, } \\
\text { Mansfield, Reading, Guildford, High Wycombe \& Aylesbury, Derby, } \\
\text { Crewe, Norwich, Chesterfield, Bournemouth, Exeter, Cambridge, } \\
\text { Slough \& Heathrow, Lincoln, York, Southampton, Eastbourne, Ipswich, } \\
\text { Trowbridge, Dunfermline \& Kirkcaldy, Wakefield, Shrewsbury, Halifax }\end{array}$ \\
\hline $\begin{array}{l}\text { Group II } \\
\text { (33 cities) }\end{array}$ & GVA 0 & $\begin{array}{l}\text { Blyth \& Ashington, Colchester, Kettering \& Wellingborough, Oxford, } \\
\text { Stevenage, Gloucester, Doncaster, Leeds, Bristol, Nottingham, } \\
\text { Chelmsford, Falkirk \& Stirling, Luton, Leicester, Worcester \& } \\
\text { Kidderminster, Chester, Southend, Sunderland, Barnsley, Warrington } \\
\text { \& Wigan, Huddersfield, Brighton, Edinburgh, Bedford, Preston, } \\
\text { Durham \& Bishop Auckland, Bradford, Manchester, Portsmouth, } \\
\text { Coventry, Cardiff, Hull, Newport }\end{array}$ \\
\hline $\begin{array}{l}\text { Group III } \\
\text { (18 cities) }\end{array}$ & GVA - & $\begin{array}{l}\text { Medway, Merthyr Tydfil, Motherwell \& Airdrie, Middlesbrough \& } \\
\text { Stockton, Sheffield, Blackburn, Plymouth, Newcastle, Birmingham, } \\
\text { Dudley, Birkenhead, Blackpool, Stoke-on-Trent, Dundee, Swansea, } \\
\text { Glasgow, Wolverhampton, Liverpool }\end{array}$ \\
\hline London & & London \\
\hline Aberdeen & & Aberdeen \\
\hline $\begin{array}{l}\text { Non-urban } \\
\text { TTWAs }\end{array}$ & & TTWAs which are not classified as cities \\
\hline
\end{tabular}

Figure A1. The contribution of economic structure and of local factors to differential output growth relative to GB growth across the City Groups, in GVA (billion fs, 2011 CMV) based on 81 sectors; Scenario 0

Group I

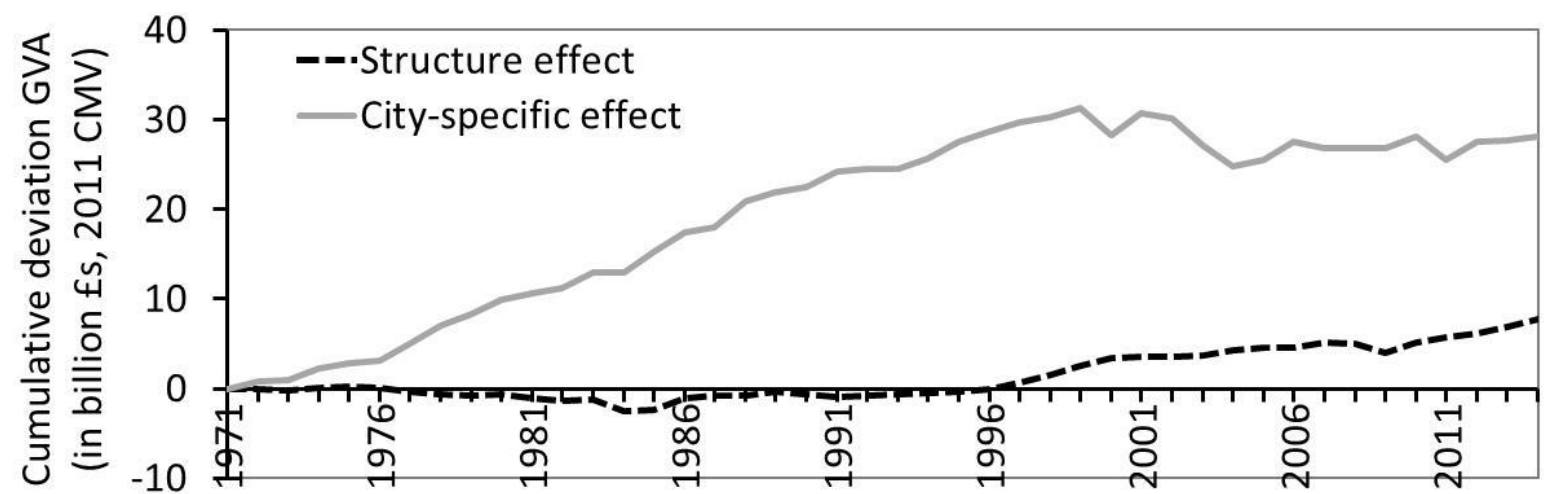


Group II

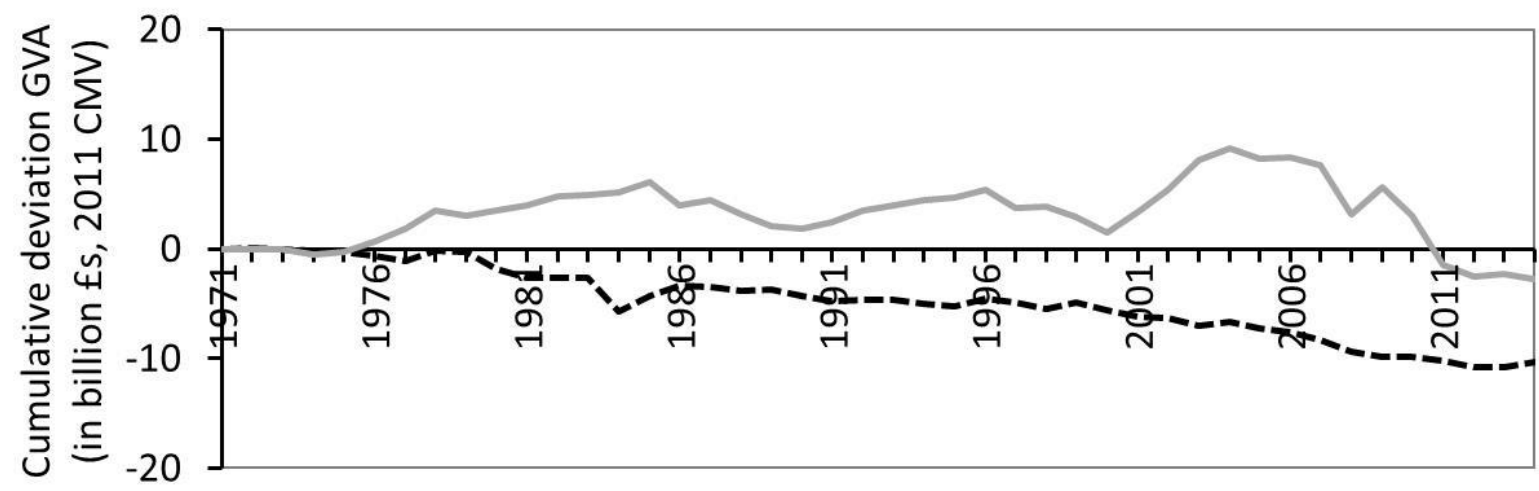

Group III

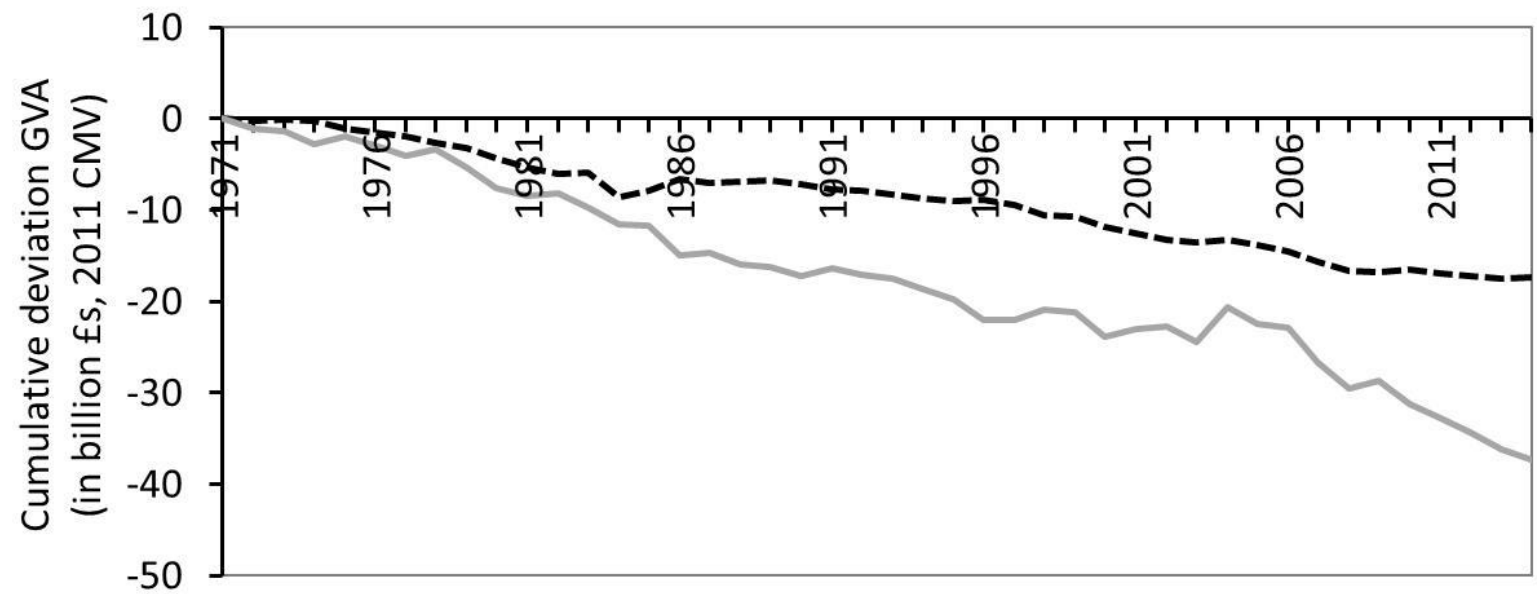

Figure A2. The contribution of economic structure and of local factors to differential output growth relative to GB growth across the City Groups, in GVA (billion fs, 2011 CMV) based on 81 sectors; Scenario 1

Group I

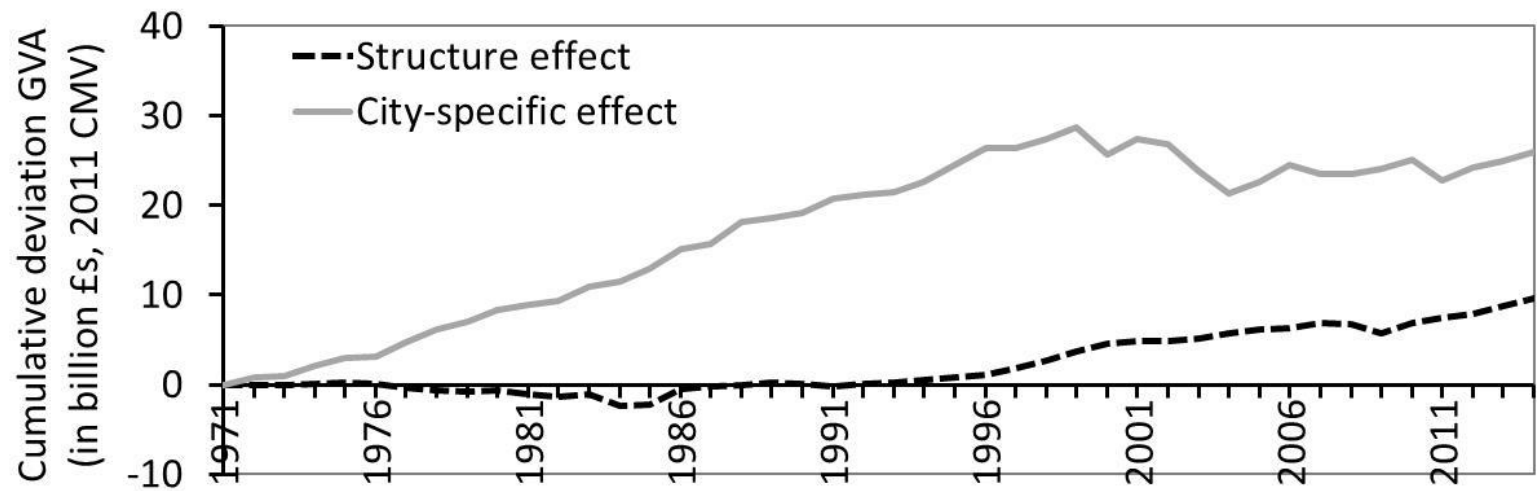


Group II

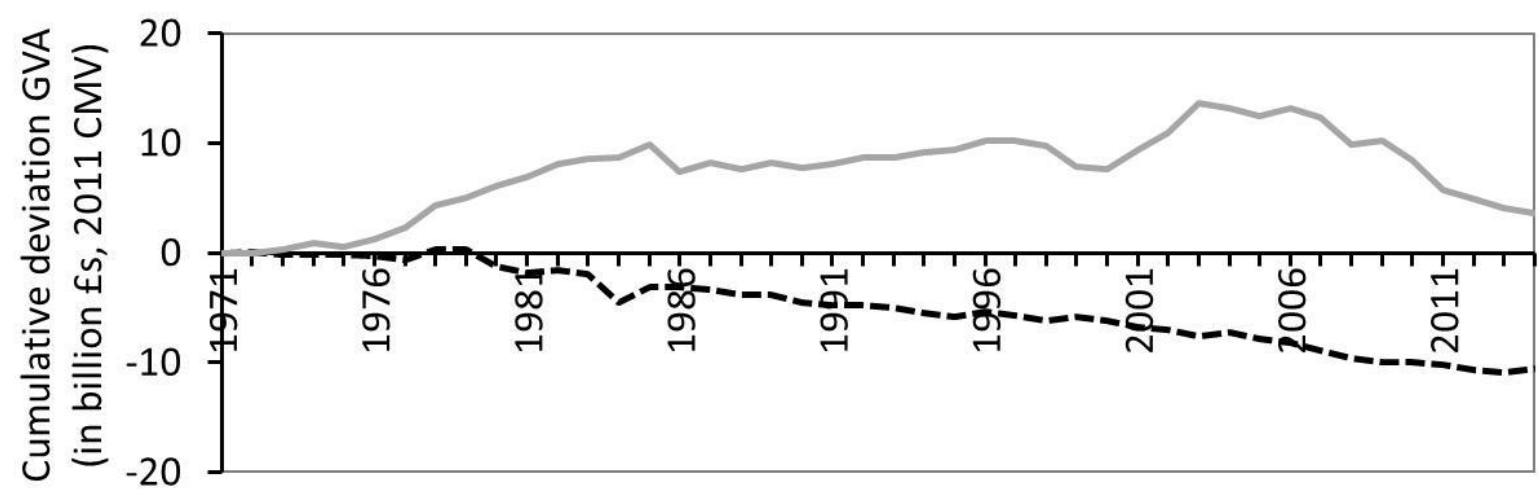

Group III

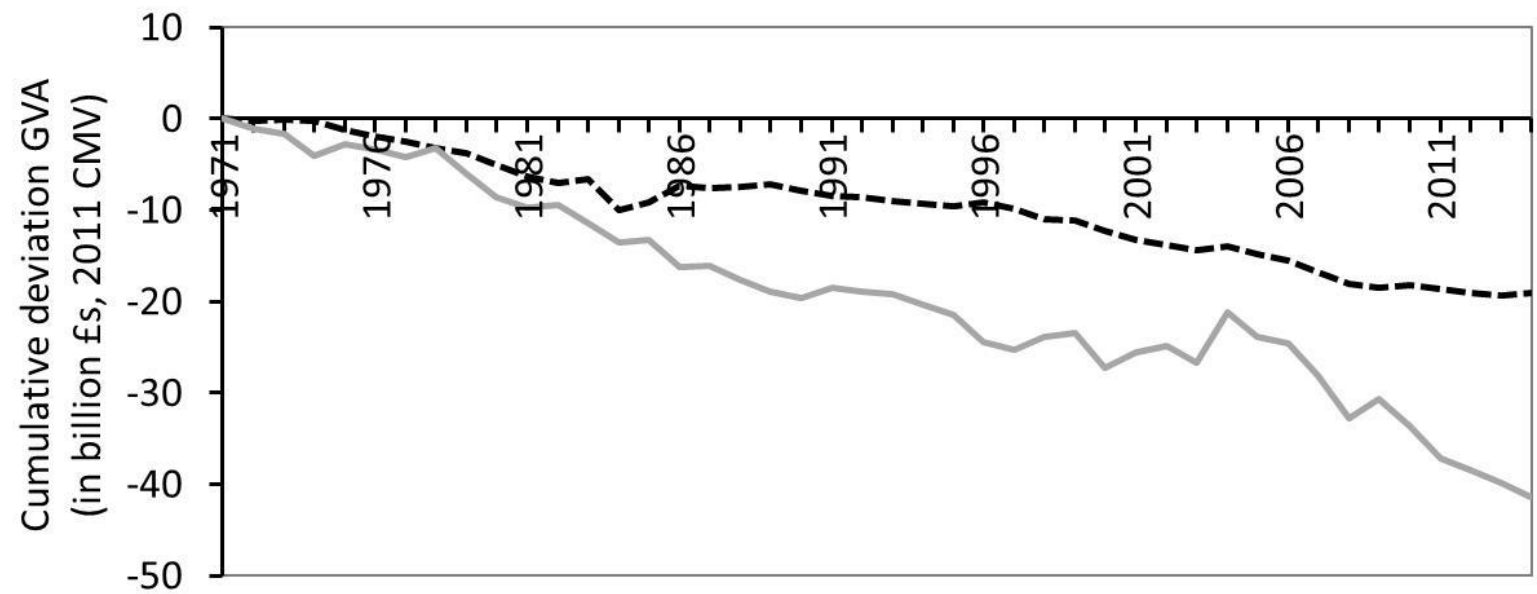

Figure A3. The contribution of economic structure and of local factors to differential output growth relative to GB growth across the City Groups, in GVA (billion $£$, 2011 CMV) based on 81 sectors; Scenario 2

Group I

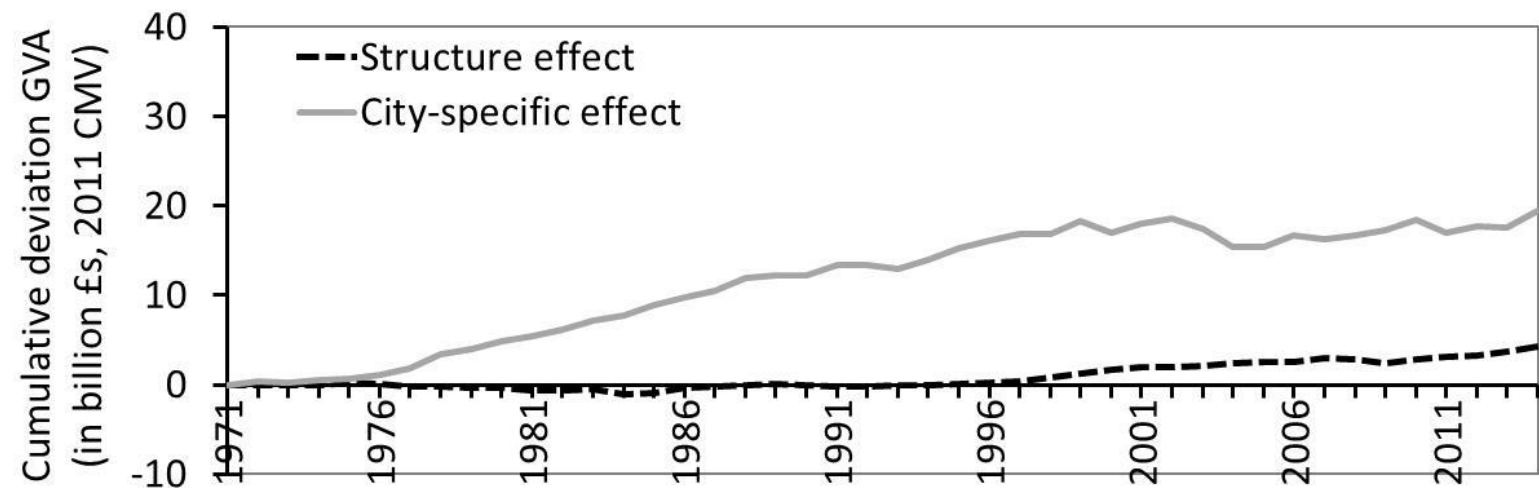


Group II

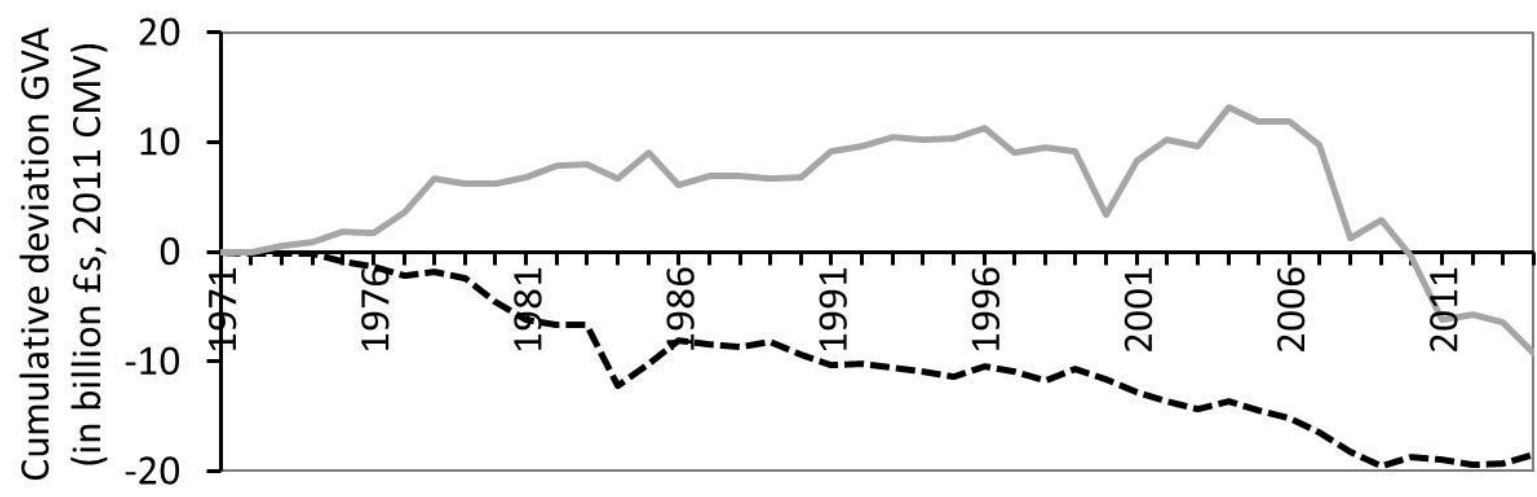

Group III

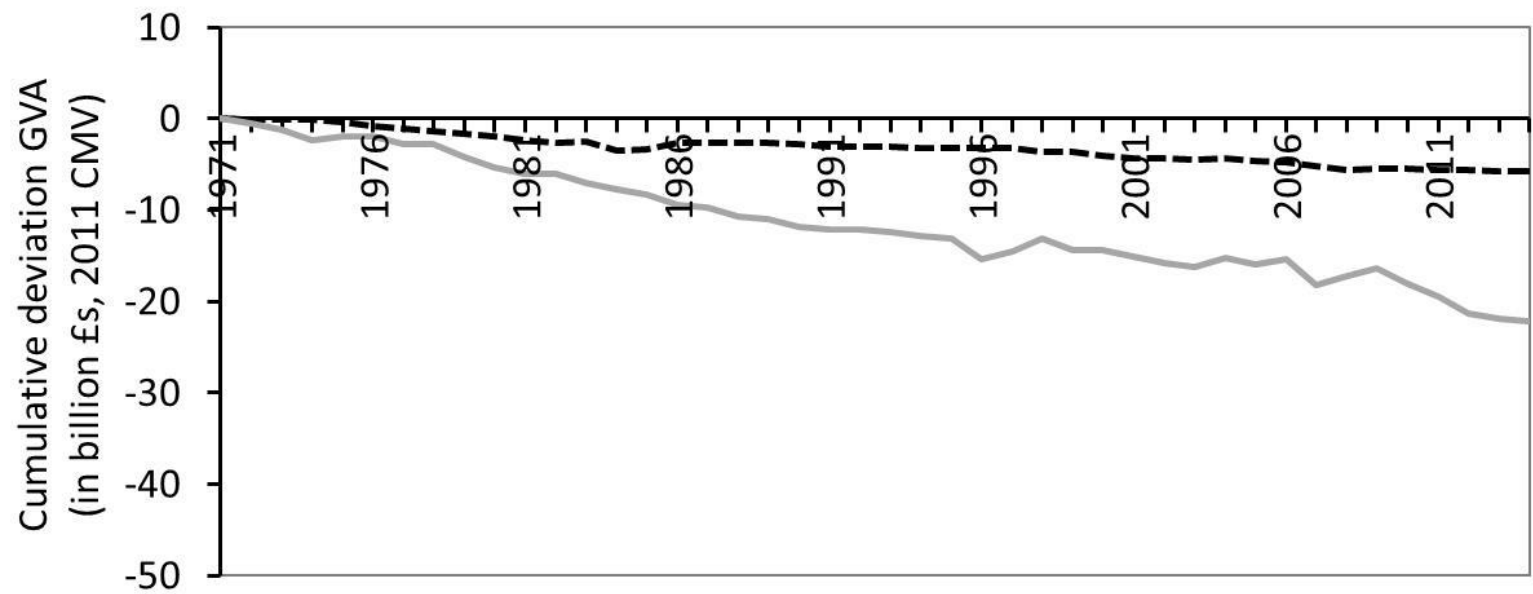

Figure A4. The contribution of economic structure and of local factors to differential output growth relative to GB growth across the City Groups, in GVA (billion fs, 2011 CMV) based on 81 sectors; Scenario 3A

Group I

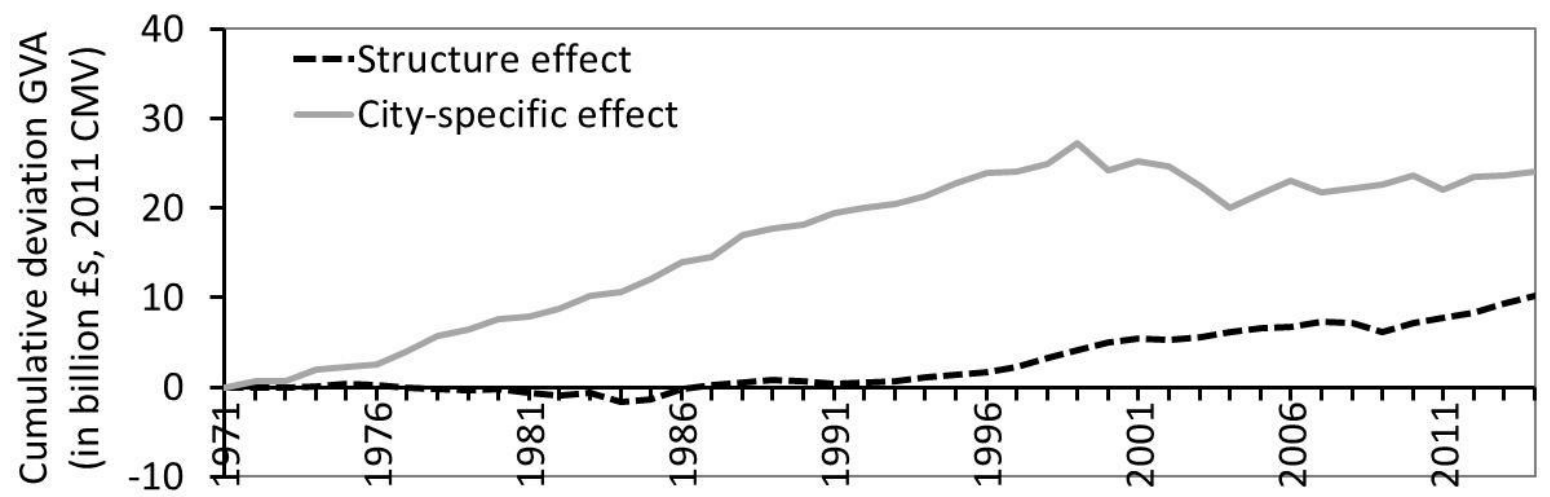


Group II

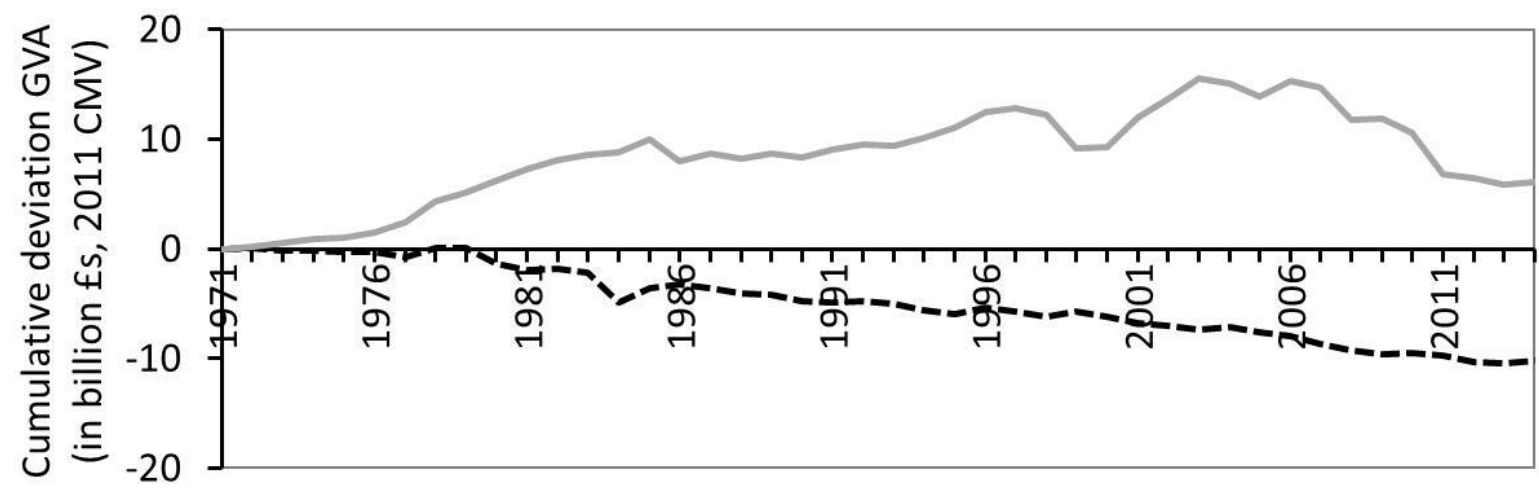

Group III

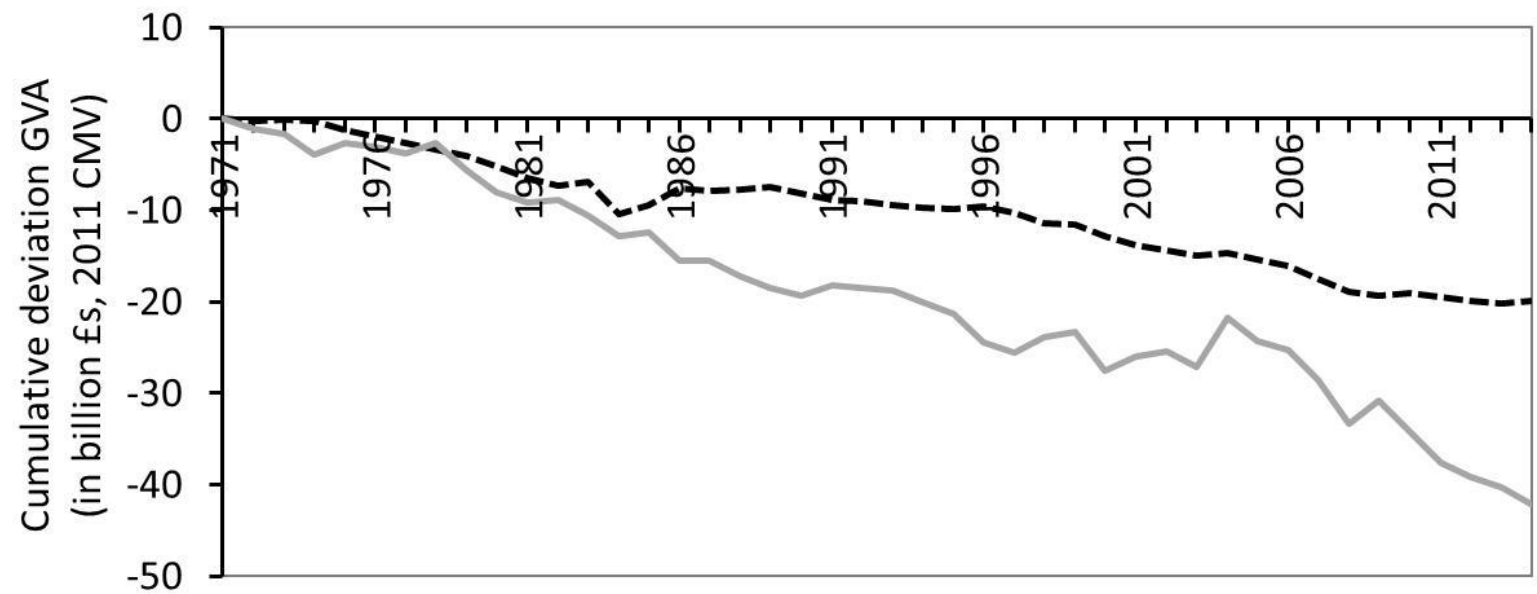

Figure A5. The contribution of economic structure and of local factors to differential output growth relative to GB growth across the City Groups, in GVA (billion fs, 2011 CMV) based on 81 sectors; Scenario 3B

Group I

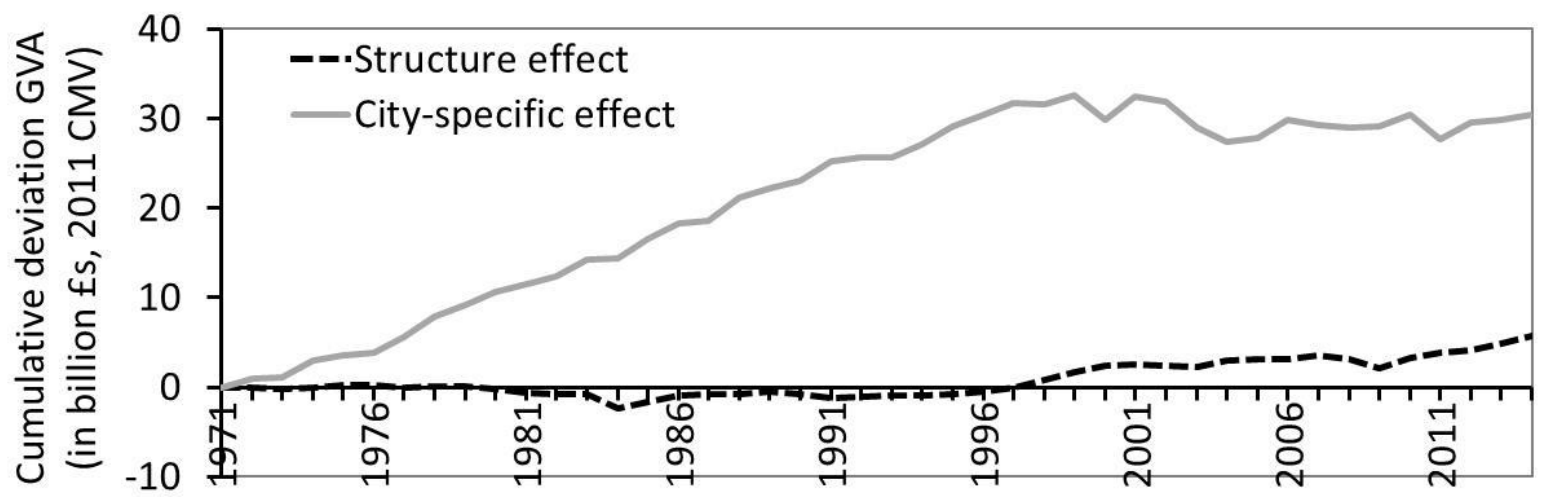


Group II

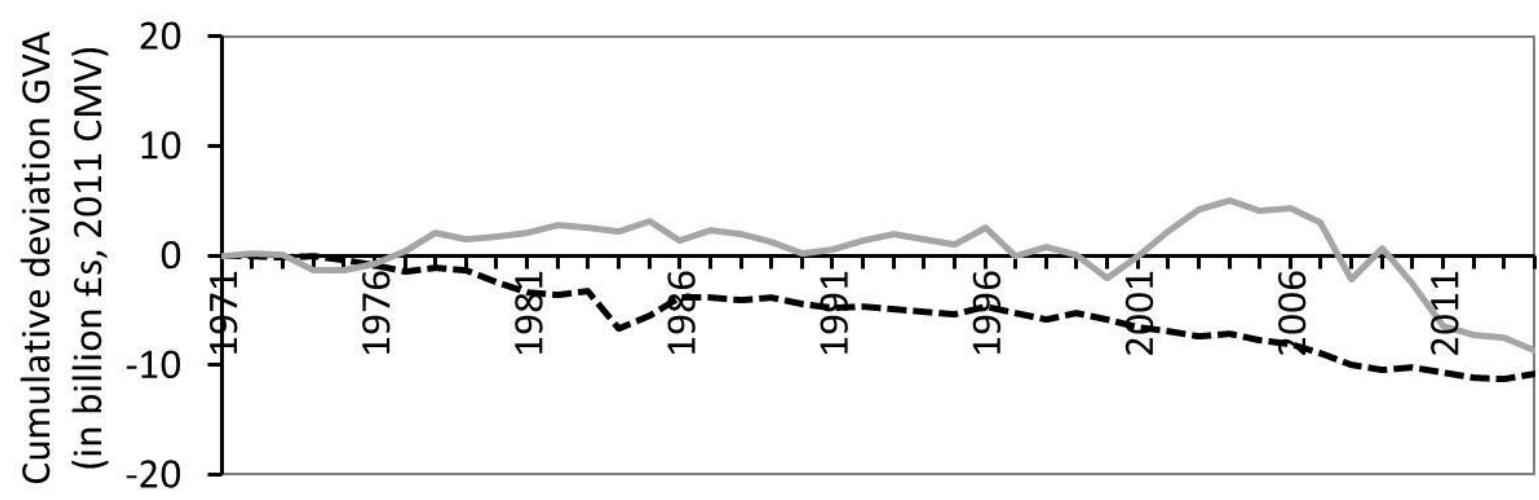

Group III

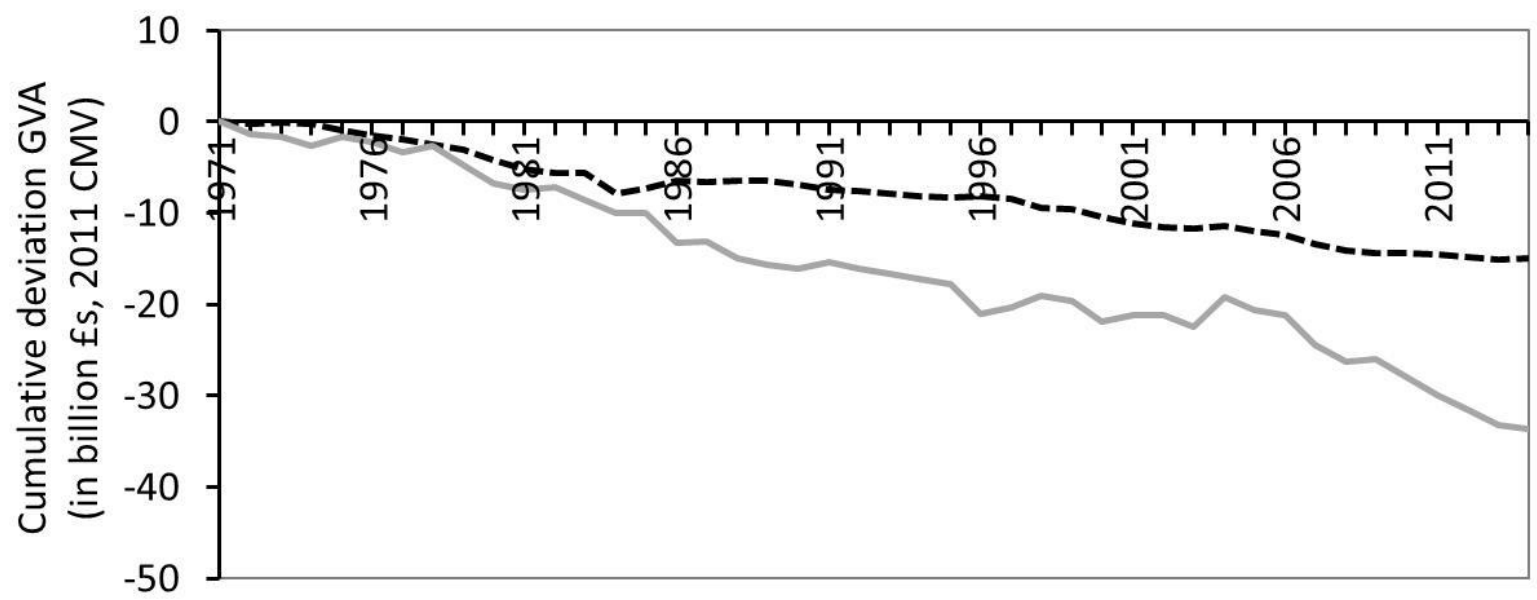

